Faculty of Humanities and Social Sciences Institute of Political Science

Working Paper Series „Glocal Governance and Democracy”

Joachim K. Blatter, Stefanie Erdmann and Katja Schwanke

Acceptance of Dual Citizenship:

Empirical Data and Political Contexts 
With its working paper series "Glocal governance and democracy" the Institute of Political Science at the University of Lucerne provides the opportunity to present conceptual ideas, normative debates and empirical findings regarding current political transformations of the modern state system. The term "glocalization" addresses key transformations in respect to levels of governance and democracy - multiplication and hybridization. These features can also be observed in the processes of horizontal interpenetration and structural overlaps among territorial units (transnationalization), in new forms of steering with actors from the private, the public and the non-profit sector (governance), in the interferences among functional regimes and discourses and in emerging new communities and networks between metropolitan centres and peripheries on various scales. One of our core themes is migration and its consequences for development, transnational integration and democracy. A second field of research and discussion is governance and democracy in functionally differentiated and multi-level systems.

Joachim K. Blatter, Stefanie Erdmann und Katja Schwanke

\title{
Acceptance of Dual Citizenship: Empirical Data and Political Contexts
}

\author{
Working Paper Series „Glocal Governance and Democracy” 02 \\ Institute of Political Science \\ University of Lucerne \\ February 2009
}

ISSN 1662-923X

Copyright by the authors

Downloads: http://www.unilu.ch/eng/workingpapers_287648.aspx

Joachim Blatter is Professor of Political Science at the University of Lucerne.

Stefanie Erdmann has been Student Assistant at the Erasmus University of Rotterdam and is now working in European Public Affairs, Brussels.

Katja Schwanke has been Research Assistant at the University of Lucerne and is PhD candidate at the University of St. Gall.

\section{Contact:}

joachim.blatter@unilu.ch

University of Lucerne

Faculty of Humanities and Social Sciences

Institute of Political Science

Hirschmattstrasse 25

Postbox 7992

CH-6000 Lucerne 7

$\mathrm{T}+41412287400$

$\mathrm{F}+41412287092$ 


\section{Abstract/Summary}

In this paper we present empirical data on the historical development, the current regulations and the political contexts of dual citizenship regulations in the world. With this focus on empirical data this report presents complementary information in respect to the first results of our research project. In the paper "Dual citizenship and democracy" Joachim Blatter (2008) discussed the normative implications of dual citizenship on the basis of six theories of democracy.

The first part contains an overview on existing surveys on dual citizenship. These surveys indicate that the acceptance of dual citizenship by countries has been rising strongly since Second World War. At the beginning of the 21st Century, from 189 analyzed countries, 87 show a rather positive stance toward dual citizenship and 77 a rather negative one. For 25 countries, the existing surveys do not provide consistent results.

In the second part of the paper, we present the findings of our own expert survey in which we collected more differentiated information about the contexts, salience, goals and specifics of dual citizenship regulation for 35 countries. Our data reveals the high political salience of citizenship regulations in many countries and the fact that the acceptance of dual citizenship is often a very controversial aspect of citizenship reforms. In line with the data in the first part of the paper, our data shows a steady trend towards broader acceptance of dual citizenship. Furthermore, we discover a trend towards more symmetric regulations of dual citizenship insofar that emigrants and immigrants are treated similar. Although this is mainly due to the fact that dual citizenship is facilitated for emigrants we do not interpret this as a re-ethnicization of citizenship but as a trend towards an expansive and non-exclusive notion of citizenship. Contrary to many normative theorists, most countries do not apply any restrictions for dual citizens in respect to political participation and in respect to taking political offices. Finally, our data does not confirm any "securitization" discourses. Both, the traditional/conservative fear that dual citizens might produce military or diplomatic conflicts between states and the liberal/critical warning that dual citizenship might be used for expelling and denationalizing migrants, which are perceived as threats to the host society, have proven unwarranted (so far).

Acknowledgments:

Research for this paper has been made possible by a grant of the Nederlandse Organisatie voor Wetenschappelijk Onderzoek (NWO) within the program „Omstreden Democratie.“ We are grateful for this support. Furthermore, we would like to thank Michael Buess for support in formatting and lay-out. 


\section{Introduction}

Dual citizenship has not only become a salient political issue in many countries (e.g. The Netherlands, Germany, Hungary, South Korea) - although in quite a few countries the rising number of dual citizens is not accompanied by a significant political discourse (e.g. in the US, Canada and Great Britain) - it is also a booming field in legal studies and the social sciences. ${ }^{1}$ Nevertheless, broad-based empirical data beyond individual case studies is still very scarce. In the first part of this paper we provide a brief overview of the results of those studies which analyzed the regulations of dual citizenship in more than a few countries. We have found only one study which reveals the rising numbers of countries with legislation allowing dual citizenship over time (Brondsted Sejersen 2008) and nine studies which look at the dual citizenship regulations at the beginning of the $21^{\text {st }}$ Century. These studies reveal a clear global trend: the acceptance of dual citizenship has strongly risen in the last twenty to thirty years and at the beginning of the $21^{\text {st }}$ Century already a majority of the countries, for which data exists, accepts or at least tolerates dual citizenship. This represents a dramatic turn-around since from the mid- $19^{\text {th }}$ century to the mid$20^{\text {th }}$ century dual citizenship was conceived as an evil which had to be prevented.

In the first part of this paper we present and comment on existing data. Although this data reveals a clear and broad-based trend towards the acceptance of dual citizenship, it shows also that many ambiguities and gaps exist. Therefore, we conducted our own expert survey in order to get a more differentiated view on the existing regulations and even more so in order to get a better understanding of the political contexts of the changes in dual citizenship regulations. The results of our own expert survey are presented in the second part of the paper.

\section{Existing data on dual citizenship}

\subsection{The rising acceptance of dual citizenship after World War II}

The only quantitative study that contains information on the historical development of dual citizenship legislation is the survey conducted by Tanja Brondsted Sejersen (2008). She collected information for 115 countries by analyzing official state Web sites and journal and newspaper articles (Brondsted Sejersen 2008: 530). Brondsted Sejerson points to the fact that her data represents the official written laws on dual citizenship and does not reflect the enforcement of these laws. Since in many countries there is a gap between the de jure and the de facto situation - quite a few countries maintain legislation against dual citizenship but do not enforce this legislation, an aspect which we investigate in depth in section 3 of this paper - her data represent a rather conservative estimate of the phenome-

$1 \quad$ Major legal studies dealing with dual citizenship include: Alainikoff and Klusmeyer 2001, 2002; Hansen and Weil 2002; Martin and Hailbronner 2003; Neuman 1994; Spiro 1997, 2006. Some of the most important contributions by social scientist are the following: Bauböck 1994; Betts 2002; Bloemraad 2004; Cain and Doherty 2006; Escobar 2004, 2006; Faist 2007; Faist and Kivisto 2007; Kivisto and Faist 2007; Kalekin-Fishman and Pitkänen 2007; Kleger 1997; Itzigsohn 2007; Jones-Correra 1998, Schröter, Mengelkamp and Jäger 2005; Mazzolori 2005. 
non of dual citizenship. Furthermore, she did not include those countries in figure 1 for which she did not obtain any information about the year of legislation (Brondsted Sejersen 2008: 531).

Figure 1, which presents her data according to the time and the region in which legislation allowing dual citizenship occurred, reveals two interesting insights: First, the rise of countries with legislation allowing dual citizenship is exponential and exhibits the strongest growth in the last 15 years. Second, the official acceptance of dual citizenship started to rise in the 1970s and 1980s in the Americas led by the countries with emigrants to the United States. This trend took off in Europe only in the 1990s and in Asia in the last few years.

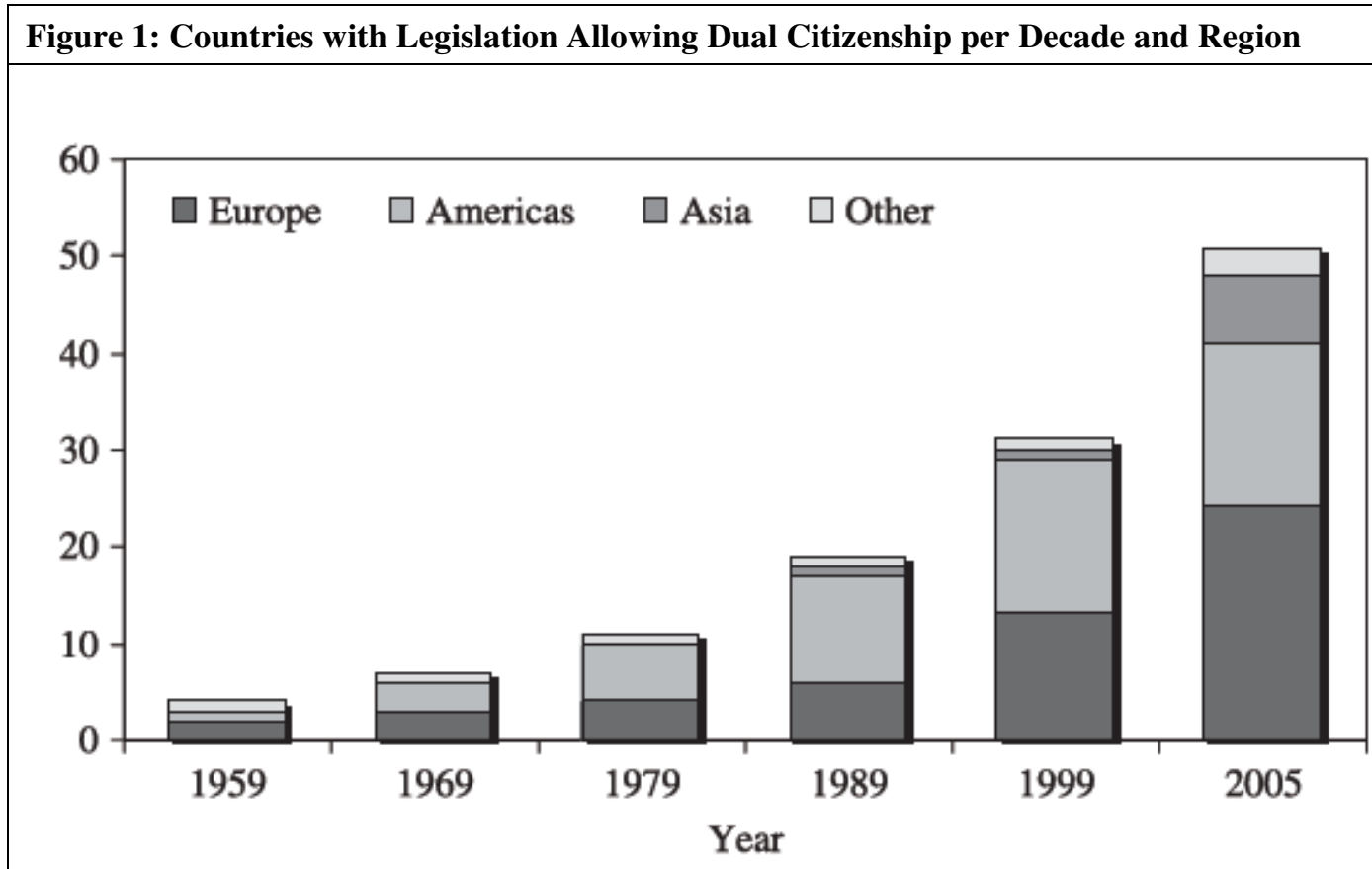

Source: Brondsted Sejersen 2008: 531

\subsection{Surveys on the acceptance of dual citizenship at the beginning of the $21^{\text {st }}$ Century}

We found nine studies with quantitative information on the spread of dual citizenship at the beginning of the $21^{\text {st }}$ Century (full bibliographic information is given in table $\mathrm{A}$ in the appendix to this chapter). Theses studies are very diverse in respect to the definitions, the number of countries included and the quality of information gathered.

There are four studies with a large number of countries and a global perspective (US Office of Personnel Management 2001, Renshon 2005, Boll 2007, Brondsted Sejersen 2008), two studies looking at the 15 older member states of the European Union (Chopin 2006, Howard 2005) and two studies focusing the Latin American and Caribbean counties (Jones-Correra 2001, Staton et al. 2007). Another one (Weil 2001) included the main Western countries plus a few East European countries. 
As it will get more and more obvious throughout this study, dual citizenship and its regulation is a complex phenomenon. This is because there are many ways to become a dual citizen, because some states do not treat immigrants equal to their emigrants and because there is sometimes a gap between the general stance towards (against) dual citizenship and the administrative practice. Furthermore, we have to differentiate between regulations which refer to the acquisition of dual citizenship and the recognition of the rights, privileges, or immunities of citizens which are connected to another citizenship by a state during the stay on the territory of this state and/or the recognition of a duty of diplomatic protection of dual citizens on the territory of the other state. In consequence, it is quite important to look at the definitions which authors apply for coding the (non-)acceptance of dual citizenship by states.

First, only one study seems to focus on the recognition of "rights, privileges, or immunities" of dual citizenships by governments (the US Office of Personnel Management 2001: 6 ), whereas all other studies concentrate on the rules that regulate the acquisition of dual citizenship.

Second, some studies take all options for becoming a dual citizen into account (by birth, by marriage, by adoption and by naturalization). In consequence, this leads to a quite extensive list of countries which allow dual citizenship "in some form" (Renshon 2005). Whereas the detailed study of Boll (2007) also provides information on all these options, we transformed his information into our overview by mainly taking into account the rules which are applied for naturalization (by emigrants and immigrants). These rules reflect best the political attitude within a country towards dual citizens and lead to a more restricted list of countries which accept dual citizenship.

Third, especially the studies which are concerned with the impact of dual citizenship in the United States focus on the rules which migrant sending countries adopt in respect to dual citizenship for emigrants (Jones-Correra 2001, Renshon 2005, Staton et al. 2007). Since countries are becoming more lenient for granting dual citizenship for their emigrants, this lead to an extensive list of countries accepting dual citizenship. Unfortunately, these studies do not provide any information whether these countries apply the rules for dual citizenship symmetrically to their immigrants. In contrast, Howard (2005) focuses explicitly on the regulations for immigrants. Whereas Boll (2007) provides information in respect to the regulations for both (and we took both aspects into account in our coding of his results), other studies are not very clear in this respect.

Forth, sometimes there exists a gap between the general stance towards dual citizenship (usually negative) and the administrative practice. Despite a general legal principle to avoid dual citizenship many countries either apply a long list of exceptions or do not enforce the requirement of renunciation if somebody takes up a new citizenship. Not all studies take these exceptions and the implementation gaps into account or they do so without making transparent how these exceptions and implementation gaps are taken into account in the overall classification. Only Boll (2007) and Chopin (2006) provide detailed information on the exceptions and the implementation of the regulations; the US Office of Personnel Management (2001) does so for some countries. 
Fifth, some countries explicitly recognize the dual citizenship of citizens with treaty nations (e.g. the ex-colonies of Spain in South America and Spain), whereas others have no such differentiated acceptance policy. In some studies, this has been a core differentiation in their own classification of countries (e.g. Jones-Correra 2001, Brondsted Sejerson 2008 ) - in consequence, we transferred this information into our overview.

\begin{tabular}{|c|c|c|}
\hline Table 1: Aggregated Results of the Individua & $\mathbf{N}$ & $\%$ \\
\hline US OPM ( $N=184$, but for 9 countries no information was available) & 175 & \\
\hline number of countries where dual citizenship is recognized & 52 & 29,7 \\
\hline number of countries where dual citizenship is not recognized & 123 & 70,3 \\
\hline $\begin{array}{l}\text { Renshon ( } N=246 \text { ISO } 3166 \text { countries, } N^{*}=144,{ }^{*} \text { Renshon listed only positive } \\
\text { cases) }\end{array}$ & 246 & \\
\hline Number of countries where dual citizenship is allowed "in some form" & 144 & 58,5 \\
\hline Number of countries where dual citizenship is not allowed "in some form" & 102 & 41,5 \\
\hline Brondsted Sejersen $(\mathrm{N}=115)$ & 115 & \\
\hline Number of countries where dual citizenship is allowed & 56 & 48,7 \\
\hline $\begin{array}{l}\text { Number of countries where dual citizenship is allowed for citizens from treaty } \\
\text { nations }\end{array}$ & 15 & 13,0 \\
\hline Number of countries where dual citizenship is not allowed & 44 & 38,3 \\
\hline Boll $(\mathbf{N}=76)$ & 76 & \\
\hline Countries where dual citizenship is recognized (in respect to naturalization) & 39 & 51,3 \\
\hline Countries where dual citizenship is tolerated (in respect to naturalization) & 25 & 32,9 \\
\hline Countries where dual citizenship is not tolerated (in respect to naturalization) & 12 & 15,8 \\
\hline Weil $(\mathbf{N}=\mathbf{2 5})$ & 25 & \\
\hline Countries where for naturalization renunciation of prior citizenship is required & 7 & 28,0 \\
\hline Countries where for naturalization renunciation of prior citizenship is not required & 18 & 72,0 \\
\hline Chopin (N = 15) & 15 & \\
\hline Countries where for naturalization renunciation of original citizenship is required & 5 & 33,3 \\
\hline $\begin{array}{l}\text { Countries where for naturalization renunciation of original citizenship is not re- } \\
\text { quired }\end{array}$ & 10 & 66,7 \\
\hline Howard $(\mathrm{N}=15)$ & 15 & \\
\hline Countries where dual citizenship is allowed for immigrants & 10 & 66,7 \\
\hline Countries where dual citizenship is not allowed for immigrants & 5 & 33,3 \\
\hline Jones-Correra $(\mathbf{N}=\mathbf{3 3})$ & 33 & \\
\hline Countries where dual citizenship is recognized & 19 & 57,6 \\
\hline Countries where dual citizenship is recognized for citizens from treaty nations & 6 & 18,2 \\
\hline Countries where dual citizenship is not recognized & 8 & 24,2 \\
\hline Staton et al. $(\mathrm{N}=\mathbf{2 0})$ & 20 & \\
\hline Countries where dual citizenship is allowed for emigrants & 12 & 60,0 \\
\hline Countries where dual citizenship is not allowed for emigrants & 8 & 40,0 \\
\hline \multicolumn{3}{|l|}{ Source: Own compilation on the basis of nine surveys } \\
\hline
\end{tabular}

Given the very different definitions and scopes of the studies, it is not surprising that the results of the various studies are not coherent (see table 1 and figure 2). Whereas the rather early study of the US Office of Personnel Management (2001) indicates that $70 \%$ of 
the analyzed countries do not recognize the second citizenship of their own citizens, Renshon's list implies a very different message: If we take into account that the UN recognizes 246 countries (according to ISO 3166), the fact that he has found 144 countries who allow dual citizenship "in some form," indicates that at least in three fifth of all countries in the world, dual citizens are not seen anymore as an evil which has to be avoided by all means. Also the other two studies (Boll 2007, Brondsted Sejersen 2008) with a global scope support the impression that, at the beginning of the $21^{\text {st }}$ century, a majority of countries allows dual citizenship - either explicitly and general or at least with specific treaty nations or by tolerating it de facto. The findings of Howard (2005) and Chopin (2006) make clear that in Western Europe the acceptance of dual citizenship has grown even more - towards two thirds of all countries. The study of Weil (2001) indicates that this level of acceptance can be generalized to the Western countries and probably also the East European countries. When we compare the findings of Jones-Correra (2001) and Staton et al. (2007) it becomes clear that this level of acceptance can also be found in South, Central and North America (including the Caribbean countries) - but only if we include those countries which restrict their acceptance of dual citizenship to members of treaty nations.

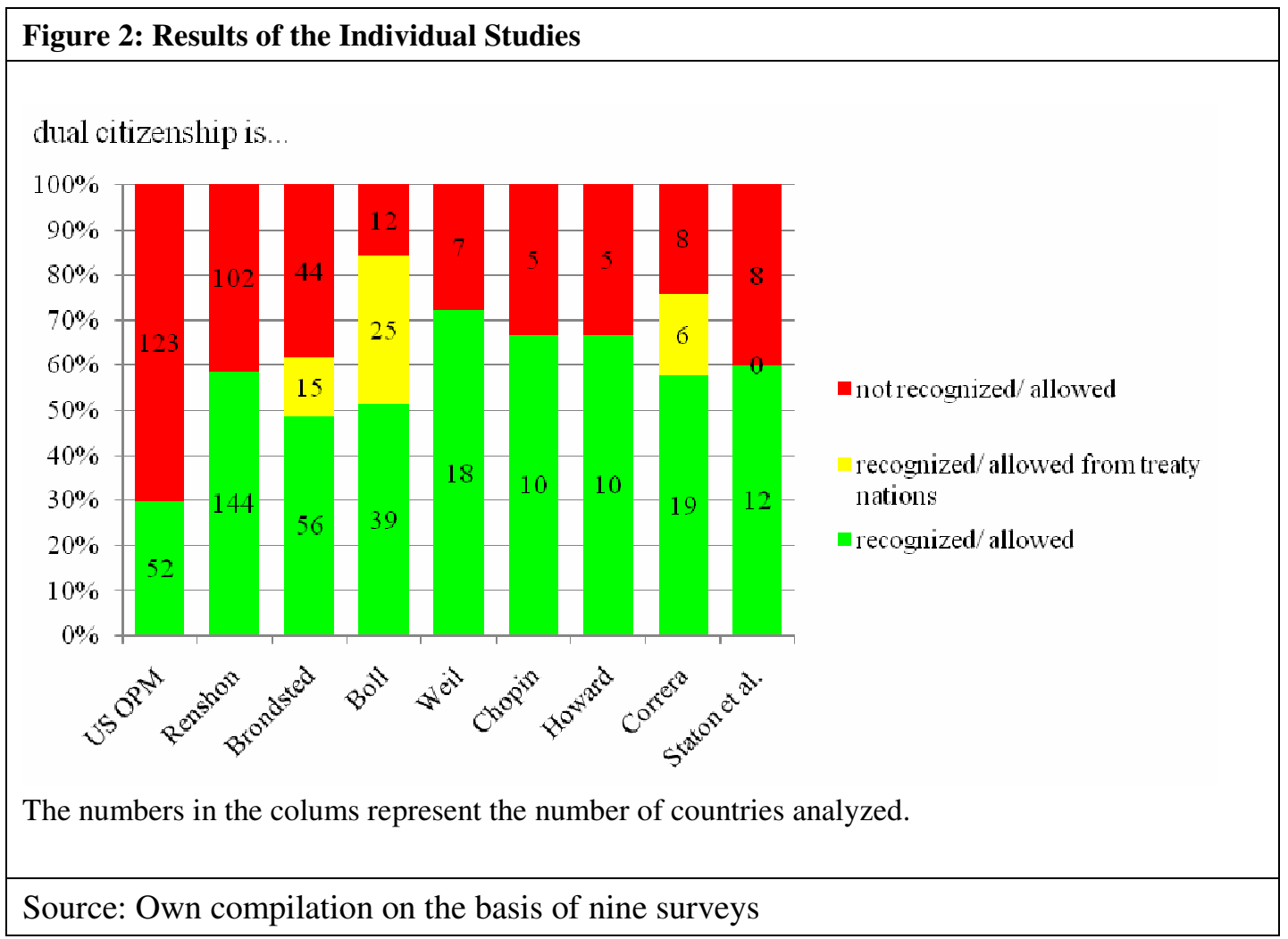

Alfred M. Boll's book is clearly the source which contains the most detailed and differentiated information on dual citizenship regulations in general and in respect to specific countries. $^{2}$ In consequence, we have taken it as the main authoritative source in our at-

2 The report by de Groot and Vink (2008) for the Dutch Advisory Council for Alien Affairs contains also detailed information and comparisons for 18 European countries. 
tempt to aggregate the information from all nine studies into the general picture on the (non-)acceptance of dual citizenship at the beginning of the $21^{\text {st }}$ century (figure 3 ). Unfortunately, he covers "only" 76 countries and for all other countries we have to rely on the findings of less detailed or less transparent studies.

We applied the following transformation rules for aggregating the findings from the different studies into the classification scheme presented in figure 3 :

- We classified all countries as "countries with no acceptance of dual citizenship" (red) if all sources classified it accordingly. Countries have also been included in this category if major sources (beyond US Office of Personnel Management (US OPM) whose focus is not on the regulation of the acquisition of dual citizenship) classified it as "not recognizing" but Renshon classified it as "allowing". Renshon's approach is too inclusive for providing an accurate picture on the current state of political acceptance of dual citizenship.

- We classified all countries as "countries with a very limited acceptance of dual citizenship" (pink) which had been classified by the US OPM as "not recognizing" but by Renshon as "allowing" dual citizenship. These countries accept dual citizenship usually only for children. When these children reach adolescence, they have to choose for only one of their citizenships.

- We classified all countries as "countries with inconsistent results" (yellow) if the diverse studies resulted in divergent classifications (beyond divergences with Renshon, which did not count).

- We classified all countries as "countries which accept dual citizenship with treaty nations or tolerate dual citizenship de facto" (light green) if studies revealed that these countries accept dual citizenship for citizens from treaty nations and/or if studies revealed that the country de facto tolerates dual citizenship through major formal exceptions from the rule of non-acceptance or through non-enforcement of this rule.

- We classified all countries as "countries with full acceptance of dual citizenship" (dark green) if all studies classified it accordingly (ignoring the US OPM classification where we had clear information that their classification represents not the current legislation anymore).

Figure 3 presents the aggregated findings of the nine studies with quantitative data on the acceptance of dual citizenship. From the 189 countries which have been analyzed, the largest group (73) fully accepts dual citizenship. Together with those countries which accept dual citizenship for citizens from treaty nations or which tolerate dual citizenship through many exceptions and/or non-enforcement of detrimental rules, this group is larger than the two groups of countries which either do not accept dual citizenship at all or which accept it only in a very limited way (usually for children). From 189 analyzed countries, 87 show a rather positive stance toward dual citizenship and 77 a rather negative one. It has to be mentioned, though, that it is quite probable, that those countries which are not included into these studies, either do not accept dual citizenship or just tolerate it (mainly by neglecting it). 


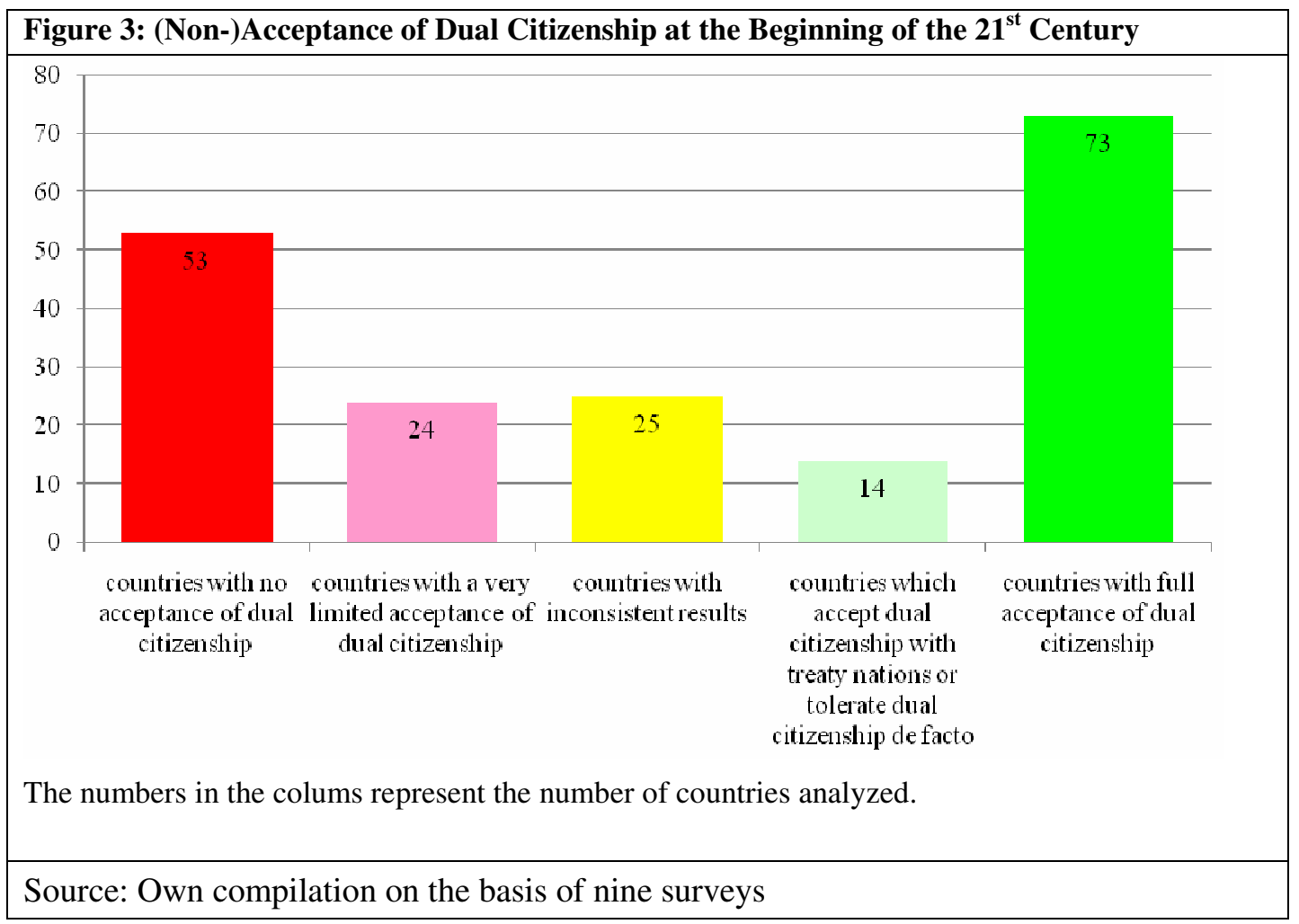

The other major result of the compilation of existing studies is the finding that for many countries (25) these studies did not produce consistent results. In light of our characterization of the different facets of dual citizenship at the beginning of this chapter, this comes with no surprise. Some inconsistencies might also be due to the fact that the legislation on dual citizenship is very much in flux. We take this result as a motivation for our attempt to get a more detailed picture of the current state of dual citizenship regulations in our own empirical investigation.

\section{Beyond acceptance versus non-acceptance: a differenti- ated look at dual citizenship regulations and their political contexts}

In this section we present the results of an expert survey that we conducted during the summer of $2008 .^{3}$ The survey had three major goals:

a) Collecting more detailed information on current national dual citizenship regulations.

b) Documenting trends in (dual) citizenship regulations over time.

c) Receiving information on the political salience of (dual) citizenship regulations.

3 Joachim Blatter developed the questionnaire on dual citizenship during a stay at the European University Institute in Florence in March 2008. He would like to thank Professor Rainer Bauböck for the invitation, the EUI for the hospitality and the NWO for finances. Rainer Bauböck, Dilek Cinar, Marc Helbling and Marc Hojé Howard provided important feed-backs and suggestions to first drafts. 
We sent a questionnaire to about 100 experts in 50 countries (the questionnaire is documented in the appendix). We tried to cover all countries in Europe and North America and the most important migrant sending countries towards Europe and North America. 45 experts filled in the questionnaire for 37 countries (the list of experts who completed the questionnaire can be found in appendix 2). These experts were selected after we conducted an extensive literature survey with a focus on publications that contained details of citizenship regulations in specific countries (the literature that we found before and through the survey is documented at the end of this report).

The fact that in eight cases we received answers from two or three different experts for the same country allowed us to reflect on the reliability of the data. Inconsistencies emerged not only in the answers to questions that refer to the political contexts and the salience of (dual) citizenship regulations. They also showed up when we asked about specific regulations. To some extent this can be seen as a result of ambiguous questions, ${ }^{4}$ but it is probably also a consequence of ambiguities in existing norms and regulations. ${ }^{5}$ The most prominent example for such an ambiguous situation can be found in the United States of America. ${ }^{6}$ As a consequence, in the following texts and tables we will not only present

There exists an unavoidable trade-off between more abstract and more specific questions and definitions. A higher level of abstraction allows applying question to a broad range of diverse countries but leaves more leeway for (divergent) interpretations and classifications. Another reason for inconsistencies which we take as an indicator for low reliability of the data is the fact that our experts represent a non-homogeneous group with different levels of expertise in respect to various aspects of our questionnaire. We also tried to find out how much discretion administrative agencies or lower levels of government have in implementing dual citizenship regulations (as another aspect of our hypothesis that there exists a gap between formal regulations and the actual praxis). The answers to the respective answers showed either a very high level of inconsistencies among the experts who reported on the same countries or a low response level. Therefore, we decided not to present these results.

The oath of allegiance that all naturalizing citizens have to swear includes the following wording: "I hereby declare, on oath, that I absolutely and entirely renounce and abjure all allegiances and fidelity to any foreign prince, potentate, state, or sovereignty, of whom or which I have heretofore been subject or citizens;..." Nevertheless, the oath has never been enforced and statements from the judicial and from the executive branch of government made the toleration of dual citizenship explicit. But the legislative branch has never enacted any law which would give the practised tolerance a clear-cut legal base (Spiro 1997). Given this ambiguity, it comes to no surprise that the two experts for the United States opted for different answers to our question whether dual citizenship is currently accepted or tolerated. One choose our first option "it is de jure accepted for both main modes of acquisition:.."; the other one found the following answer more appropriate: "It is de jure in principle not accepted, but de facto it is quite common because of many exceptions and/or as a result of minimal controls." 
aggregated data but indicate the classification of each country in each table as well. This leads to a maximum of transparency.

The clear majority of the countries in our sample are European countries (see figure 1). 20 are members of the European Union: Austria, Denmark, Estonia, Finland, Germany, Greece, Hungary, Ireland, Italy, Latvia, Lithuania, Luxembourg, Malta, the Netherlands, Poland, Portugal, Slovakia, Slovenia, Spain, and Sweden. Another eight countries are neighbors of the EU: Algeria, Croatia, Israel, Lebanon, Morocco, Switzerland, Turkey, and Ukraine. Our sample covers all three North American countries (Canada, Mexico, and the USA) and two countries from South America (Brazil and Columbia). The following countries from other parts of the world complete the sample: Australia, Japan, South Africa, and South Korea.

Figure 1: Countries in our sample

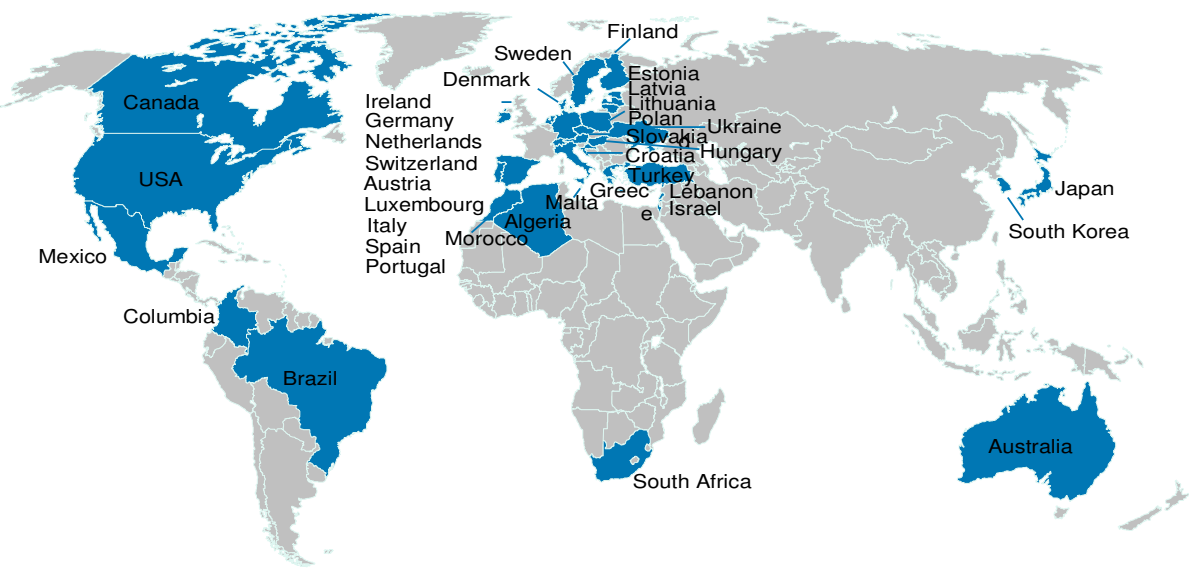

\subsection{General regulations of citizenship: contexts, salience, goals and trends}

\section{Contexts}

The sample covers most developed Western countries that are usually the targets of immigration. Therefore, it is no surprise that in many countries of our sample (in 16 countries) recent regulation of citizenship has taking place basically in the context of debates about immigration (see table 2.1). This has also been the case in two classic migrant sending countries: Mexico and Turkey. Nevertheless, table 2.1 also reveals that in a majority of the countries in our sample nation state building is still (or again) a very important issue. In Columbia, Estonia, Greece, Latvia, Poland, South Africa, Spain and Ukraine controversies about the protection of minorities within or outside the boundaries of the nation state are 
looming large. In these eight countries this discourse in providing the most important context for citizenship regulation and in eleven countries it plays a very significant role in addition to migration.

\begin{tabular}{|l|c|l|}
\hline Table 2.1 & Recent regulations of citizenship have taking place... \\
\hline All received answers & 35 & \\
\hline $\begin{array}{l}\text { a) ...basically in the context of debates about } \\
\text { (im)migration }\end{array}$ & $\begin{array}{c}14 \\
(+2)\end{array}$ & $\begin{array}{l}\text { Algeria, Austria, Canada, Denmark, } \\
\text { Germany, Italy, Japan, Luxembourg, } \\
\text { Malta, Mexico, Portugal, Slovakia, } \\
\text { Sweden, (Switzerland), Turkey, (USA) }\end{array}$ \\
\hline $\begin{array}{l}\text { b) ...basically in the context of debates about } \\
\text { nation state building (protection/ participation } \\
\text { of "own" minorities beyond state boundaries or } \\
\text { of "foreign" minorities within state boundaries) }\end{array}$ & 8 & $\begin{array}{l}\text { Columbia, Estonia, Greece, Latvia, } \\
\text { Poland, South Africa, Spain, Ukraine }\end{array}$ \\
\hline $\begin{array}{l}\text { c) ...both contexts played a very significant } \\
\text { role }\end{array}$ & 11 & $\begin{array}{l}\text { Australia, Croatia, Finland, Hungary, } \\
\text { Ireland, Israel, Lithuania, Morocco, } \\
\text { Netherlands, Slovenia, South Korea, } \\
\text { (Switzerland), (USA) }\end{array}$ \\
\hline
\end{tabular}

Brackets "( )" indicate that the experts for these countries provided different answers.

\section{Salience}

In about half of the countries in which the regulation of citizenship has taken place in the context of immigration policy, this issue has been politically very important (see table 2.2).

Table 2.2 Has the issue of immigration been a salient political issue during the last 15-20 years?

\begin{tabular}{|l|c|l|}
\hline All received answers & 27 & \\
\hline $\begin{array}{l}\text { a) It has very often been one of the top three political } \\
\text { issues and has influenced the party system/the com- } \\
\text { position of the ruling party/coalition in government }\end{array}$ & $\begin{array}{c}7 \\
(+1)\end{array}$ & $\begin{array}{l}\text { Australia, Austria, Croatia, Den- } \\
\text { mark, (Germany), Morocco, Ne- } \\
\text { therlands, Switzerland, }\end{array}$ \\
\hline $\begin{array}{l}\text { b) It has very often been one of the top three political } \\
\text { issues but has not influenced the party sys- } \\
\text { tem/composition of government significantly }\end{array}$ & 3 & $\begin{array}{l}\text { (Canada), Finland, (Germany), } \\
\text { Ireland, (Israel), (Italy), Mexico } \\
(+4)\end{array}$ \\
\hline $\begin{array}{l}\text { c) It has sometimes been one of the top three political } \\
\text { issues and dominated the public discourse during this } \\
\text { time }\end{array}$ & $\begin{array}{c}8 \\
(+2)\end{array}$ & $\begin{array}{l}\text { (Canada), Hungary, (Italy), Japan, } \\
\text { Lithuania, Luxembourg, Slovenia, } \\
\text { South Korea, Sweden, USA }\end{array}$ \\
\hline d) It has seldom been a major political issue & $\begin{array}{c}4 \\
(+1)\end{array}$ & $\begin{array}{l}\text { Algeria, (Israel), Malta, Portugal, } \\
\text { Turkey, }\end{array}$ \\
\hline e) It has never been a major political issue & 1 & Slovakia \\
\hline
\end{tabular}

Brackets "( )" indicate that the experts for these countries provided different answers. 
In Australia, Austria, Croatia, Denmark, Germany, Morocco, the Netherlands and Switzerland the issue of immigration has not only been very often one of the top three issues on the political agenda but it has influenced the party system and/or the composition of the ruling party or coalition in government. In another seven countries it has been very often one of the top three issues on the political agenda but without such an influence on the party system or the composition of the government. If the regulation of citizenship has been taken place in the context of nation state building the political salience of this context is even bigger. For nine countries the experts reported an influence of this issue on the party system and/or on the composition of the ruling coalition/party (see table 2.3 ). In another seven countries nation state building has been very often or sometimes one of the top three political issues.

\begin{tabular}{l|l} 
Table 2.3 & Has the issue of nation state building has been a salient political issue during the
\end{tabular} last 20 years?

\begin{tabular}{|l|c|l|}
\hline All received answers & 22 & \\
\hline $\begin{array}{l}\text { a) It has very often been one of the top three po- } \\
\text { litical issues and has influenced the party sys- } \\
\text { tem/the composition of the ruling party/coalition } \\
\text { in government }\end{array}$ & $\begin{array}{c}7 \\
(+2)\end{array}$ & $\begin{array}{l}\text { Croatia, Estonia, (Israel), Latvia, } \\
\text { Morocco, Netherlands, Slovenia, } \\
\text { South Africa, (Switzerland) }\end{array}$ \\
\hline $\begin{array}{l}\text { b) It has very often been one of the top three po- } \\
\text { litical issues but has not influenced the party sys- } \\
\text { tem/composition of government significantly }\end{array}$ & $\begin{array}{c}3 \\
(+1)\end{array}$ & $\begin{array}{l}\text { Greece, Lithuania, (Switzerland), } \\
\text { Ukraine }\end{array}$ \\
\hline $\begin{array}{l}\text { c) It has sometimes been one of the top three po- } \\
\text { litical issues and dominated the public discourse } \\
\text { during this time }\end{array}$ & 4 & $\begin{array}{l}\text { Australia, Hungary, Ireland, (Israel), } \\
\text { South Korea, }\end{array}$ \\
\hline d) It has seldom been a major political issue & 4 & $\begin{array}{l}\text { Columbia, Denmark, Finland, Po- } \\
\text { land, }\end{array}$ \\
\hline e) It has never been a major political issue & 2 & Spain, USA \\
\hline
\end{tabular}

Brackets "( )" indicate that the experts for these countries provided different answers.

For the two issues, immigration and nation state building, we can differentiate between the political dimension and economic and socio-cultural aspects. When it comes to immigration policy political participation of immigrants is in most countries less important and less controversial than their economic and socio-cultural integration. Nevertheless, for Canada, Croatia, Germany, Luxembourg and Switzerland at least one expert perceives political participation as the most controversial aspect of the national integration policy (see table 2.4). The political dimension looms larger where nation state building is the primary context for citizenship regulation (see table 2.5). According to at least one expert, in Estonia, Ireland, Israel and Latvia, political membership is clearly the most important and most controversial aspect in this debate. In Croatia, Greece, Switzerland and Ukraine 
it is not the most important but the most controversial aspect. Furthermore, in most countries that are still struggling with nation-state building formal political membership is as important and as controversial as the protection of economic interests and socio-cultural identities.

\begin{tabular}{|l|l|l|l|}
\hline Table 2.4 & \multicolumn{3}{|l}{$\begin{array}{l}\text { How prominent has the aspect of POLITICAL integration/ participation (citizen- } \\
\text { ship with an emphasis on political rights and duties) been in the debate on immi- } \\
\text { gration (in comparison to economic and socio-cultural integration)? }\end{array}$} \\
\hline All received answers & 27 & \\
\hline $\begin{array}{l}\text { a) Political integration/participation is clearly the } \\
\text { most important and the most controversial aspect }\end{array}$ & 0 & \\
\hline $\begin{array}{l}\text { b) Political integration/participation is not the most } \\
\text { important but the most controversial aspect }\end{array}$ & 2 & $\begin{array}{l}\text { (Canada), Croatia, (Germany), } \\
\text { Luxembourg, (Switzerland) }\end{array}$ \\
\hline $\begin{array}{l}\text { c) Political integration/participation is as important } \\
\text { and as controversial as economic and socio-cultural } \\
\text { integration }\end{array}$ & 6 & $\begin{array}{l}\text { (Austria), Hungary, Italy, Mo- } \\
\text { rocco, Netherlands, Slovenia, } \\
\text { (Switzerland), Turkey }\end{array}$ \\
\hline $\begin{array}{l}\text { d) Political integration/participation is less important } \\
\text { and less controversial than economic and socio- } \\
\text { cultural integration }\end{array}$ & 11 & $\begin{array}{l}\text { Australia, (Austria), (Canada), } \\
\text { Finland, (Germany), Israel, Ja- } \\
\text { pan, Lithuania, Malta, Mexico, } \\
\text { Portugal, Slovakia, South Korea, } \\
\text { Sweden, (Switzerland), (USA) }\end{array}$ \\
\hline $\begin{array}{l}\text { e) Political integration/participation does not play any } \\
\text { significant role }\end{array}$ & $\begin{array}{c}3 \\
(+1)\end{array}$ & $\begin{array}{l}\text { Algeria, Denmark, Ireland, } \\
\text { (USA) }\end{array}$ \\
\hline
\end{tabular}

Brackets "( $)$ " indicate that the experts for these countries provided different answers.

\begin{tabular}{|l|l|}
\hline Table 2.5 & How prominent has the aspect of POLITICAL membership (nationality regula-
\end{tabular} tions) been in the debate on nation state building (in comparison to economic and socio-cultural participation/ protection of minorities)?

\begin{tabular}{|l|c|l|}
\hline All received answers & 21 & \\
\hline $\begin{array}{l}\text { a) Political membership is clearly the most important } \\
\text { and the most controversial aspect }\end{array}$ & $\begin{array}{c}3 \\
(+1)\end{array}$ & Estonia, Ireland, (Israel), Latvia \\
\hline $\begin{array}{l}\text { b) Political membership is not the most important but } \\
\text { the most controversial aspect }\end{array}$ & $\begin{array}{c}3 \\
(+1)\end{array}$ & $\begin{array}{l}\text { Croatia, (Greece), Switzerland, } \\
\text { Ukraine, }\end{array}$ \\
\hline $\begin{array}{l}\text { c) Political membership is as important and as con- } \\
\text { troversial as economic and socio-cultural participa- } \\
\text { tion/protection }\end{array}$ & 9 & $\begin{array}{l}\text { Australia, Columbia, (Greece), } \\
\text { Hungary, (Israel), Lithuania, } \\
(+2)\end{array}$ \\
$\begin{array}{l}\text { Morocco, Netherlands, Poland, } \\
\text { Slovenia, South Africa, }\end{array}$ \\
\hline $\begin{array}{l}\text { d) Political membership is less important and less } \\
\text { controversial than economic and socio-cultural par- } \\
\text { ticipation/protection }\end{array}$ & 2 & Finland, South Korea, \\
\hline $\begin{array}{l}\text { e) Political membership does not play any significant } \\
\text { role }\end{array}$ & 2 & Spain, USA \\
\hline Brats ()" & & \\
\hline
\end{tabular}

Brackets "( )" indicate that the experts for these countries provided different answers. 


\section{Trend in respect to openness}

Our survey reveals a surprisingly clear and - maybe even more surprisingly - stable trend towards citizenship regulations that make access to national citizenship easier. For 22 countries, at least one expert concluded that overall the last reform made it easier to acquire citizenship in that country. In contrast, only nine experts reported that the last reform made it more difficult. For six experts the last reform in their country exhibits elements that make it easier to acquire citizenship and other elements that make it more difficult (see table 2.6). From the 26 experts who judged the overall direction of the second-last reform, 13 perceived the overall trend in the second-last reform also as making access to citizenship easier. In five countries the second-last reform made the acquisition of citizenship more difficult and in eight countries our experts discovered elements of both (see table 2.7).

\begin{tabular}{|l|c|l|}
\hline Table 2.6 & \multicolumn{2}{|l|}{$\begin{array}{l}\text { Overall, did the last reform make access to citizenship/nationality easier or more } \\
\text { difficult? }\end{array}$} \\
\hline $\begin{array}{l}\text { All received } \\
\text { answers }\end{array}$ & 33 & \\
\hline a) Easier & $\begin{array}{c}19 \\
(+3)\end{array}$ & $\begin{array}{l}\text { Algeria, (Canada), Columbia, Croatia, Finland, Hungary, (Italy), Japan, } \\
\text { Latvia, Luxembourg, Malta, Mexico, Morocco, Poland, Portugal, Slovakia, } \\
\text { South Korea, Spain, Sweden, Switzerland, Ukraine (USA) }\end{array}$ \\
\hline $\begin{array}{l}\text { b) More } \\
\text { difficult }\end{array}$ & $\begin{array}{c}7 \\
(+2)\end{array}$ & $\begin{array}{l}\text { Australia, Austria, Denmark, Estonia, Germany, Ireland, (Israel), Lithua- } \\
\text { nia, (USA) }\end{array}$ \\
\hline c) Both & $\begin{array}{c}3 \\
(+3)\end{array}$ & (Canada), Greece, (Israel), (Italy), Netherlands, Slovenia \\
\hline
\end{tabular}

\begin{tabular}{|l|c|l|}
\hline Table 2.7 & \multicolumn{2}{|l|}{$\begin{array}{l}\text { Overall, did the second-last reform make access to citizenship/nationality easier or } \\
\text { more difficult? }\end{array}$} \\
\hline $\begin{array}{l}\text { All received } \\
\text { answers }\end{array}$ & 26 & \\
\hline a) Easier & 13 & $\begin{array}{l}\text { Canada, Germany, Ireland, Latvia, Lithuania, Malta, Mexico, Morocco, Por- } \\
\text { tugal, Slovakia, Switzerland, Ukraine, USA }\end{array}$ \\
\hline $\begin{array}{l}\text { b) More } \\
\text { difficult }\end{array}$ & 5 & Algeria, Australia, Austria, Netherlands, Poland \\
\hline c) Both & 8 & Estonia, Finland, Greece, Hungary, Italy, Slovenia, South Korea, Sweden \\
\hline
\end{tabular}

Brackets "( )" indicate that the experts for these countries provided different answers.

If we compare the direction of change between the last and the second-last reform, in Germany, Ireland, and Lithuania we discover a turn from making citizenship acquisition easier towards being more restrictive. In contrast, the following countries stayed on a path towards more openness: Canada, Latvia, Malta, Mexico, Morocco, Portugal, Slovakia, 
Switzerland, Ukraine and the United States ${ }^{7}$. For Algeria and Poland, the experts reported that the latest reform had a liberal tendency whereas the second-last reform was restrictive. In contrast, Australia and Austria have been steadily moving towards a more restrictive citizenship policy.

It has to be stressed, though, that these results point towards directions of change, they say nothing about the absolute level of openness in respect to the acquisition of citizenship. For receiving more precise information about such absolute levels of openness we concentrated our inquiry to the regulations concerning dual citizenship (see next section).

\section{Goals}

Before we zoom in to the specifics of dual citizenship we have a look at the goals that were supposed to be achieved by the citizenship law reforms during the last decades (see tables 2.8 and 2.9). Until now, only a few countries seem to perceive citizenship regulations as a means to attract "useful" immigrants. The competition for human capital in the context of economic globalization has not (yet) spilled over into citizenship policy. Gender equation - another discourse which has been identified as an important source for citizenship reforms in the $20^{\text {th }}$ century in the literature seems to play no big role anymore in most countries of our sample. The goal that is connected most often with citizenship reforms in the last decades is still "strengthening national identity and cohesion." In some cases this goal leads to a more restrictive policy in respect to access to citizenship (e.g. in Australia, Estonia, Ireland, Lithuania), nevertheless, there exist also cases in which this goal correlates with citizenship regulations which made access to citizenship easier (e.g. in Hungary, Japan, Latvia, Poland and Portugal). This seems to be the case because this goal can be combined with goals which imply a less restrictive approach to granting citizenship. In the cases of Hungary and Poland, the goal to strengthen the ties to the diasporas, in combination with the goal to strengthen national identity and cohesion lead to a more inclusive citizenship policy. But also the combination with the goal to facilitate the integration of immigrants can have the same result as the examples of Latvia and Portugal show. In the last decades, both motives - facilitating the integration of immigrants and strengthening the ties to emigrants and expatriates - seem to play as similar broad role in citizenship policies.

$7 \quad$ We have inconsistent classifications for the US because of different judgments of what has been the last relevant reform. If we take the answers of the expert which judged on the ba- 


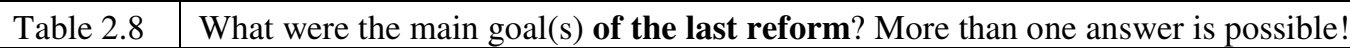

\begin{tabular}{|c|c|c|c|}
\hline \multicolumn{2}{|c|}{$\begin{array}{l}\text { a) Attracting new immi- } \\
\text { grants (e.g. skilled work- } \\
\text { ers) }\end{array}$} & $\begin{array}{c}1 \\
(+3)\end{array}$ & Finland, (Israel), (Switzerland), (USA) \\
\hline \multicolumn{2}{|c|}{$\begin{array}{l}\text { b) Facilitating the integra- } \\
\text { tion of existing immigrants }\end{array}$} & $\begin{array}{c}8 \\
(+4)\end{array}$ & $\begin{array}{l}\text { (Austria), (Canada), Finland, (Greece), (Italy), Latvia, Neth- } \\
\text { erlands, Portugal, Slovenia, Sweden, Switzerland, Ukraine }\end{array}$ \\
\hline \multicolumn{2}{|c|}{$\begin{array}{l}\text { c) Strengthening ties to } \\
\text { emigrants or diasporas }\end{array}$} & $\begin{array}{c}9 \\
(+4) \\
\end{array}$ & $\begin{array}{l}\text { Finland, (Greece), Hungary, (Israel), (Italy), Malta, Moroc- } \\
\text { co, Netherlands, Poland, Slovenia, Spain, (Sweden), Turkey }\end{array}$ \\
\hline \multicolumn{2}{|c|}{ d) Gender equalization } & $\begin{array}{c}3 \\
(+2) \\
\end{array}$ & Algeria, (Canada), Morocco, Slovakia, (Switzerland) \\
\hline \multicolumn{2}{|c|}{$\begin{array}{l}\text { e) Strengthening national } \\
\text { identity/cohesion }\end{array}$} & $\begin{array}{l}15 \\
(+2)\end{array}$ & $\begin{array}{l}\text { Australia, Brazil, Estonia, (Germany), Greece, Hungary, } \\
\text { Ireland, Israel, (Italy), Japan, Latvia, Lithuania, Netherlands, } \\
\text { Poland, Portugal, Slovenia, South Africa }\end{array}$ \\
\hline \multicolumn{2}{|c|}{$\begin{array}{l}\text { f) Securing autonomy/ in- } \\
\text { tegrity/safety for the native } \\
\text { population }\end{array}$} & $\begin{array}{c}4 \\
(+1)\end{array}$ & Estonia, (Germany), Poland, South Africa, South Korea \\
\hline Table 2.9 & \multicolumn{3}{|c|}{$\begin{array}{l}\text { What were the main goal(s) of the second-last reform? More than one answer is } \\
\text { possible! }\end{array}$} \\
\hline
\end{tabular}

a) Attracting new immigrants (e.g. skilled workers)

b) Facilitating the integration of existing immigrants

c) Strengthening ties to emigrants or diasporas

d) Gender equalization

e) Strengthening national identity/cohesion

f) Securing autonomy/ integrity/safety for the native population

\begin{tabular}{|c|l|}
$\begin{array}{c}1 \\
(+1)\end{array}$ & (Germany), Japan, \\
\hline $\begin{array}{c}7 \\
(+3)\end{array}$ & (Austria), (Canada), Estonia, Germany, Japan, Morocco, \\
\hline 9 & Estonia, Greece, Hungary, (Italy), Lithuania, Malta, Portu- \\
$(+2)$ & gal, Slovenia, Spain, (Sweden), Turkey \\
\hline 2 & (Canada), Portugal, South Korea, (Sweden), (Switzerland), \\
$(+4)$ & (USA) \\
\hline $\begin{array}{c}11 \\
(+4)\end{array}$ & $\begin{array}{l}\text { Algeria, Brazil, (Canada), Estonia, Finland, (Greece), Hun- } \\
\text { gary, Ireland, (Israel), (Italy), Latvia, Morocco, Slovakia, }\end{array}$ \\
\hline 2 & Slovenia, Ukraine \\
$(+2)$ & Estonia, Finland, (Greece), (Israel) \\
\hline
\end{tabular}

Brackets "( )" indicate that the experts for these countries provided different answers.

A remarkable contrast emerges when we look at the answers to the question: What were the main goal(s) of the major failed reform attempt? Failed reform attempts have been significantly less often connected to the goal of strengthening national identity or cohesion than successful reform proposals (see table 2.10). 
Table 2.10 $\quad$ What were the main goal(s) of major failed reform attempt? More than one answer is possible!

\begin{tabular}{l|c|l|}
\hline $\begin{array}{l}\text { a) Attracting new immi- } \\
\text { grants (e.g. skilled work- } \\
\text { ers) }\end{array}$ & $\begin{array}{c}1 \\
(+2)\end{array}$ & (Germany), Lebanon, (Switzerland) \\
\hline $\begin{array}{l}\text { b) Facilitating the integra- } \\
\text { tion of existing immigrants }\end{array}$ & $\begin{array}{c}7 \\
(+4)\end{array}$ & $\begin{array}{l}\text { (Austria), (Germany), Italy, Latvia, Morocco, Netherlands, } \\
\text { Poland, Spain, (Sweden), Switzerland, (USA) }\end{array}$ \\
\hline $\begin{array}{l}\text { c) Strengthening ties to } \\
\text { emigrants or diasporas }\end{array}$ & $\begin{array}{c}4 \\
(+1)\end{array}$ & Hungary, (Italy), Lithuania, Lebanon, Poland, \\
\hline $\begin{array}{l}\text { d) Gender equalization } \\
\text { e) Strengthening national }\end{array}$ & $\begin{array}{c}2 \\
(+3)\end{array}$ & (Austria), (Canada), (Germany), Hungary, Poland \\
\hline $\begin{array}{l}\text { identity/cohesion } \\
\text { f) Securing autonomy/ } \\
\text { integrity/safety for the } \\
\text { native population }\end{array}$ & $\begin{array}{c}4 \\
(+3)\end{array}$ & $\begin{array}{l}\text { (Germany), (Israel), Latvia, Poland, Portugal, Slovenia, } \\
\text { (USA) }\end{array}$ \\
\hline
\end{tabular}

This confirms the importance of this goal not only as a still widespread motive but as an important success factor. It is important to realize that this motive does neither necessarily lead to a more restrictive citizenship policy in general nor to the non-acceptance of dual citizenship as we will see in the next chapter.

\subsection{Reregulating dual citizenship: salience, specifics, drivers and conse- quences}

Given the high political salience of immigration and nation state building in many countries, it comes with no surprise that new citizenship regulations have been introduced in recent years. Yet it remains remarkable that new regulations have been introduced in ALL countries of our sample ${ }^{8}$ - although it might well be that there exists a systematic bias in our sample since it is plausible that among the experts we asked the ones who reported on countries in which changes have taken place have been more motivated to respond. In 23 countries (out of 35 countries for which we received answers to this question) there has been a change in citizenship law with an effect on dual citizenship since the year 2000. All other countries in our sample changed their citizenship laws during the 1990s. For the majority of the countries, the latest reform of regulations with an impact on the acceptance of dual citizenship has not been the only one taking place in recent years. 20 countries have had another reform just a few years before the latest reform and for about half of the countries the experts reported reform attempts which failed since $1990{ }^{9}$

8 The only exception is Denmark. But in Denmark, attempts to reform the citizenship law have been underway in mid-2008 when we conducted our survey.

9 The year and the name of the regulation which the experts have seen as the last and the second-last reforms of citizenship law or of other regulations which have had an effect on 


\section{Salience of dual citizenship regulations}

Asked how important the issue of dual citizenship was in the latest reform of the citizenship law, 10 experts reported that dual citizenship was absolutely central in the country they reported on. This is about a third of all responses to this question, about another third answered that dual citizenship was not important at all and the remaining third rated the importance of dual citizenship in the latest citizenship reform in between (see table 2.11). We received similar balanced response rates when we asked about the importance of dual citizenship in the second-last reform. Interestingly, though, when we asked how important the aspect of dual citizenship was in failed attempts to reform the national citizenship law, almost all of the 15 experts who responded to this question, reported that dual citizenship was absolutely central or very central.

\begin{tabular}{|l|c|l|}
\hline Table 2.11 & \multicolumn{3}{|c|}{ How important/central was the issue of dual citizenship in the last reform? } \\
\hline All answers & 33 & \\
\hline a) $1=$ central & $9(+1)$ & $\begin{array}{l}\text { Finland, Italy, Lithuania, Malta, Mexico, Morocco, South Korea, } \\
\text { Sweden, (Switzerland), Turkey }\end{array}$ \\
\hline b) 2 & $4(+1)$ & (Canada), Hungary, Luxembourg, Netherlands, Spain \\
\hline c) 3 & $3(+2)$ & (Austria), Poland, Portugal, (Switzerland), Ukraine \\
\hline d) 4 & $4(+2)$ & Algeria, Brazil, (Canada), Estonia, (Greece), Slovenia \\
\hline $\begin{array}{l}\text { e) } 5=\text { not important } \\
\text { at all }\end{array}$ & $9(+3)$ & $\begin{array}{l}\text { Australia, (Austria), Columbia, Croatia, (Greece), Ireland, Israel, } \\
\text { Japan, Latvia, Slovakia, (Switzerland), USA }\end{array}$ \\
\hline
\end{tabular}

Note: Brackets "( )" indicate that the experts for these countries provided different answers.

\section{Acceptance and tolerance of dual citizenship}

When we look at the current state of affairs in respect to the regulation of dual citizenship, we discover that our sample contains almost only countries that now accept or at least tolerate dual citizenship. Only Austria, Lithuania and South Korea neither accept dual citizenship de jure nor tolerate it de facto because they have almost no exceptions and strictly enforce there restrictive regulations. Since our perspective on dual citizenship has been strongly colored by prior knowledge of the situations and developments in the Netherlands, Germany and the United States, we have been surprised by the fact that in 21 countries dual citizenship is not only tolerated but de jure accepted for the two main

dual citizenship are documented in the raw data set which will be available online. One of the major reasons for inconsistencies in the answers of the experts which reported about the same country results from the fact, that very often they have taken different legal acts as "last reform" and "second last reform" in our questionnaire. 
modes of acquisition (by birth and by naturalization) - and that this formal acceptance is symmetric. Emigrants, who acquire another nationality abroad, can keep the citizenship of these countries; but also immigrants can keep the citizenship of their country of decent when they become citizens of these countries (see table 2.12).

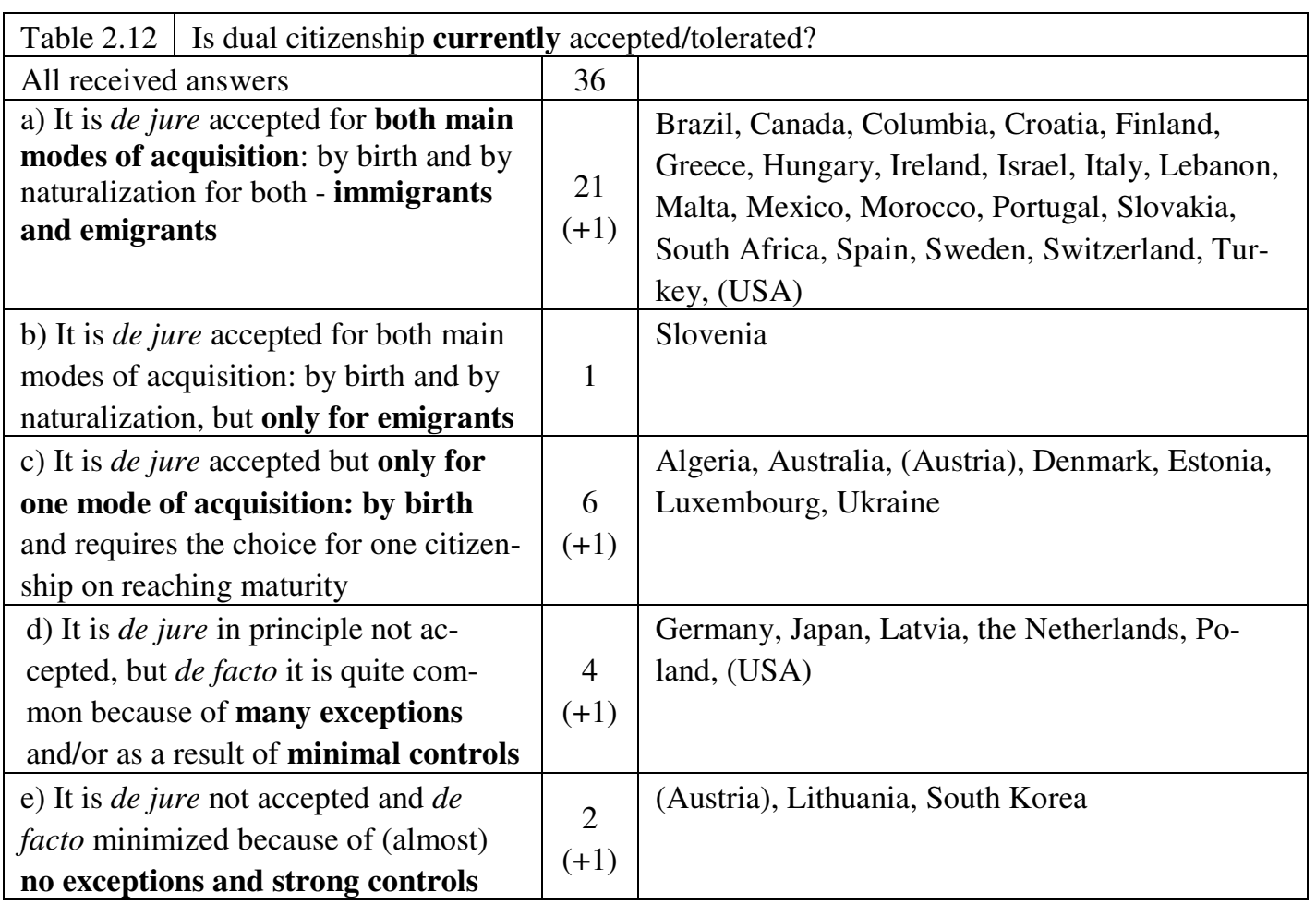

Only in Germany, Japan, Latvia, the Netherlands, Poland, and the USA, there is a gap between (some) principled norms and rules, which are restrictive, and the praxis, which is more tolerant. This tolerance can be a consequence of the fact that laws and other formal regulations include many exceptions from the general restrictive principle or can result from a lenient enforcement of restrictive norms.

Since we are interested in the long-term development of dual citizenship regulations we asked our experts also whether dual citizenship was accepted or tolerated before the latest reform and before the second-last reform. Although we have to acknowledge growing inconsistencies in the responses to these answers, the general trend is clear (see tables 2.13 and 2.14). 
Table 2.13 Was dual citizenship accepted/tolerated before the last reform?

\begin{tabular}{|l|c|l|}
\hline All received answers & 34 & \\
\hline $\begin{array}{l}\text { a) It is de jure accepted for both main modes of } \\
\text { acquisition: by birth and by naturalization for } \\
\text { both - immigrants and emigrants }\end{array}$ & 12 & $\begin{array}{l}\text { Croatia, Greece, Hungary, Ireland, Israel, } \\
\text { (Italy) Malta, Mexico, Morocco, Portu- } \\
\text { gal, South Africa, Spain, (Switzerland), } \\
\text { Turkey, (USA) }\end{array}$ \\
\hline $\begin{array}{l}\text { b) It is de jure accepted for both main modes of } \\
\text { acquisition: by birth and by naturalization, but } \\
\text { only for emigrants }\end{array}$ & 3 & $\begin{array}{l}\text { Lithuania, Lebanon, Slovenia, (Switzer- } \\
\text { land) }\end{array}$ \\
\hline $\begin{array}{l}\text { c) It is de jure accepted but only for one mode } \\
\text { of acquisition: by birth and requires the choice } \\
\text { for one citizenship on reaching maturity }\end{array}$ & $\begin{array}{c}(+1) \\
(+2)\end{array}$ & $\begin{array}{l}\text { (Austria), Canada, Estonia, (Sweden), } \\
\text { Ukraine }\end{array}$ \\
\hline $\begin{array}{l}\text { d) It is de jure in principle not accepted, but } d e \\
\text { facto it is quite common because of many ex- } \\
\text { ceptions and/or as a result of minimal controls }\end{array}$ & $\begin{array}{c}7 \\
(+3)\end{array}$ & $\begin{array}{l}\text { Australia, Finland, Germany, (Italy), } \\
\text { Japan, Latvia, Luxembourg, Poland, } \\
\text { (Sweden), (USA) }\end{array}$ \\
\hline $\begin{array}{l}\text { e) It is de jure not accepted and de facto mini- } \\
\text { mized because of (almost) no exceptions and } \\
\text { strong controls }\end{array}$ & $\begin{array}{c}4 \\
(+1)\end{array}$ & $\begin{array}{l}\text { Algeria, (Austria), Columbia, Slovakia, } \\
\text { South Korea }\end{array}$ \\
\hline
\end{tabular}

Table 2.14 $\quad$ Was multiple/dual citizenship accepted/tolerated before the second-last reform?

\begin{tabular}{|c|c|c|}
\hline All received answers & 29 & \\
\hline $\begin{array}{l}\text { a) It is de jure accepted for both main modes } \\
\text { of acquisition: by birth and by naturalization } \\
\text { for both - immigrants and emigrants }\end{array}$ & $\begin{array}{c}9 \\
(+1)\end{array}$ & $\begin{array}{l}\text { Greece, Ireland, Malta, Mexico, Moroc- } \\
\text { co, Portugal, Slovakia, South Africa, } \\
\text { Spain, (USA) }\end{array}$ \\
\hline $\begin{array}{l}\text { b) It is de jure accepted for both main modes of } \\
\text { acquisition: by birth and by naturalization, but } \\
\text { only for emigrants }\end{array}$ & 4 & $\begin{array}{l}\text { Hungary, Lithuania, Slovenia, Switzer- } \\
\text { land }\end{array}$ \\
\hline $\begin{array}{l}\text { c) It is de jure accepted but only for one mode } \\
\text { of acquisition: by birth and requires the choice } \\
\text { for one citizenship on reaching maturity }\end{array}$ & $\begin{array}{c}0 \\
(+1)\end{array}$ & $(\mathrm{Au}$ \\
\hline $\begin{array}{l}\text { d) It is de jure in principle not accepted, but de } \\
\text { facto it is quite common because of many ex- } \\
\text { ceptions and/or as a result of minimal con- } \\
\text { trols }\end{array}$ & $\begin{array}{c}7 \\
(+1)\end{array}$ & $\begin{array}{l}\text { Australia, Germany, Japan, Latvia, } \\
\text { Luxembourg, Turkey, Ukraine, (USA) }\end{array}$ \\
\hline $\begin{array}{l}\text { e) It is de jure not accepted and de facto mini- } \\
\text { mized because of (almost) no exceptions and } \\
\text { strong controls }\end{array}$ & $\begin{array}{c}7 \\
(+1)\end{array}$ & $\begin{array}{l}\text { Algeria, (Austria), Estonia, Finland, } \\
\text { Lebanon, Poland, South Korea, Sweden }\end{array}$ \\
\hline
\end{tabular}

Within our sample, the number of countries that fully and formally accept dual citizenship has steadily grown and the number of countries that neither de jure accept nor de facto tolerate dual citizenship has steadily declined. With the notable exception of the Netherlands, no country in our sample has experienced any reform in citizenship law that reduced the existing openness towards dual citizenship. In the Netherlands, a reform of the citizenship law in 1993 brought a full-fledged acceptance of dual citizenship for immigrants (but not for long term emigrants) by abolishing the renunciation requirement for those who naturalize in the Netherlands. Another reform, adopted in 2000, reinstated the 
renunciation requirement for immigrants and at the same time provided the long-term acceptance of dual citizenship for expatriates (de Hart 2007: 88-94).

\section{(A)Symmetry of dual citizenship regulations}

Against the background of the Dutch experience, which exemplifies a perceived general trend towards a re-ethnicization and de-territorialization of citizenship based on the ius sanguinis principle (see Joppke 2003, Cinar 2008), the following results in respect to the symmetry or asymmetry of dual citizenship regulations are remarkable. We asked our experts whether the regulations on dual citizenship are/were symmetric in respect to emigrants and immigrants. Unfortunately, we did not ask whether an asymmetric regulation favors emigrants or immigrants, but we provided the following explanation and specifications to this question: ${ }^{10}$

The regulations are fully symmetric if they have the following features:

(a) it does not matter which nationality has been acquired first for the (non-)acceptance of dual nationality upon naturalization, which means that the country under consideration demands the same from immigrants which want to naturalize in this country as from the emigrants which want to naturalize in another country (de facto, de jure or no renunciation of the other citizenship) - this aspect should be given double weight in comparison to the following aspects;

(b) children of mixed marriages get citizenship of the country under consideration irrespective of whether they are born in that country or in the country of nationality of the other parent;

(c) it does not matter which nationality has been acquired first when it comes to rights and restrictions for political participation (voting, taking offices), which means that immigrants (which have acquired the nationality of the country under consideration after the nationality of the country of origin) have exactly the same rights and restrictions than emigrants (which have acquired the nationality of the country under consideration before the nationality of the other country);

(d) it does not matter which nationality has been acquired first in respect to issues like military service, diplomatic protection and judicial cooperation (e.g. extradition of criminals) - because these issues are regulated on the basis of other principles like e.g. habitual residence.

Currently, 21 out of 29 countries have fully symmetric or almost fully symmetric regulations in respect to emigrants and immigrants. From our sample, only Israel, Mexico, Finland, Poland, Japan, Latvia and Turkey discriminate between emigrants and immigrants (see table 2.15).

10 We have to acknowledge that this question has been at the same time too overloaded with different aspects and not inclusive enough in respect to an important aspect (the direction of potential asymmetries). 
We asked the same question in respect to the situation before the last reform (see table 2.16). ${ }^{11}$ The responses reveal that the latest reforms tended to make dual citizenship regulations more symmetrical since a few countries moved from a more asymmetrical situation towards a more symmetrical situation: Finland and Israel (which nevertheless still exhibit rather asymmetrical regulations), as well as Portugal, Sweden and Switzerland. Although a closer look at these cases would be necessary in order to reach a solid conclusion, these results provide some evidence for the following hypothesis: The growing inclination of states to accept emigrants and expatriates as their citizens is not so much a shift from a territorial conception of citizenship towards an ethnic or uis sanguinis-based definition of citizenship as it is a shift towards an expansive and non-exclusive notion of citizenship.

\begin{tabular}{|l|c|l|}
\hline Table 2.15 & \multicolumn{2}{|l|}{$\begin{array}{l}\text { Are the regulations on dual citizenship currently symmetric in respect to emi- } \\
\text { grants and immigrants? }\end{array}$} \\
\hline $\begin{array}{l}\text { All received } \\
\text { answers }\end{array}$ & 29 & \\
\hline $\begin{array}{l}\text { a) } 1=\text { fully } \\
\text { symmetric }\end{array}$ & 12 & $\begin{array}{l}\text { Algeria, Columbia, Greece, Hungary, Ireland, Italy, Morocco, South } \\
\text { Korea, Spain, Sweden, Ukraine, USA }\end{array}$ \\
\hline b) 2 & 9 & $\begin{array}{l}\text { Australia, Austria, Croatia, Estonia, Germany, Portugal, Slovakia, Slove- } \\
\text { nia, Switzerland }\end{array}$ \\
\hline c) 3 & 2 & Israel, Mexico \\
\hline d) 4 & 2 & Finland, Poland \\
\hline $\begin{array}{l}\text { e) } 5=\text { fully } \\
\text { asymmetric }\end{array}$ & 3 & Japan, Latvia, Turkey \\
\hline
\end{tabular}

\begin{tabular}{|l|c|l|}
\hline Table 2.16 & \multicolumn{2}{|l|}{$\begin{array}{l}\text { Were the regulations on dual citizenship symmetric in respect to emigrants and } \\
\text { immigrants before the last reform? }\end{array}$} \\
\hline $\begin{array}{l}\text { All received } \\
\text { answers }\end{array}$ & 27 & \\
\hline $\begin{array}{l}\text { a) } 1=\text { fully } \\
\text { symmetric }\end{array}$ & $9(+1)$ & $\begin{array}{l}\text { Algeria, Greece, Hungary, Ireland, (Italy), Morocco, South Korea, Spain, } \\
\text { Ukraine, USA }\end{array}$ \\
\hline b) 2 & $6(+1)$ & Australia, (Austria), Croatia, Estonia, Germany, Slovakia, Slovenia, \\
\hline c) 3 & $2(+2)$ & (Austria), (Italy), Sweden, Turkey \\
\hline d) 4 & $3(+1)$ & Netherlands, Poland, Portugal, (Switzerland) \\
\hline $\begin{array}{l}\text { e) } 5=\text { fully } \\
\text { asymmetric }\end{array}$ & $4(+1)$ & Finland, Israel, Japan, Latvia, (Switzerland) \\
\hline
\end{tabular}

11 We also asked about the situation before the second-last reform. The response rate to this question dropped sharply so that we cannot draw any conclusion in respect to the long term development. 


\section{Dual nationals and political participation}

In the normative debate on dual citizenship even some of those who endorse the acceptance of dual citizenship in general argue for some restrictions when it comes to taking offices or in respect to political participation in both countries at the same time ( Bauböck 2003: 33, Alainikoff and Klusmeyer 2002: 41). Our survey reveals that most countries in our sample are more tolerant. Only in Australia, Columbia and South Korea dual citizens are not allowed to take political offices. Finland, Japan and Mexico apply such a restriction only for higher-level political offices. All other countries allow dual citizens to be political representatives and/or executives at all levels (for Israel and Sweden we received inconsistent results, see tables 2.17 and 2.18).

\begin{tabular}{|l|c|l|}
\hline \multicolumn{2}{|l|}{ Table 2.17 } & Are dual nationals legally allowed to take a lower-level political office? \\
\hline $\begin{array}{l}\text { All } \\
\text { received } \\
\text { answers }\end{array}$ & 28 & \\
\hline a) Yes & 25 & $\begin{array}{l}\text { Algeria, Austria, Croatia, Denmark, Estonia, Finland, Greece, Hungary, Ire- } \\
\text { land, Israel, Italy, Japan, Lebanon, Latvia, Morocco, Netherlands, Poland, Por- } \\
\text { tugal, Slovenia, South Africa, Spain, Sweden, Switzerland, Turkey, USA }\end{array}$ \\
\hline b) No & 3 & Australia, Columbia, South Korea \\
\hline
\end{tabular}

\begin{tabular}{|l|c|l|}
\hline \multicolumn{2}{|l|}{ Table 2.18 } & Are dual nationals legally allowed to take a higher-level political office? \\
\hline $\begin{array}{l}\text { All } \\
\text { received } \\
\text { answers }\end{array}$ & 31 & \\
\hline a) Yes & $\begin{array}{c}23 \\
(+2)\end{array}$ & $\begin{array}{l}\text { Algeria, Austria, Croatia, Denmark, Estonia, Greece, Hungary, Ireland, (Israel), } \\
\text { Italy, Latvia, Lebanon, Lithuania, Morocco, Netherlands, Poland, Portugal, } \\
\text { Slovakia, Slovenia, South Africa, Spain, (Sweden), Switzerland, Turkey, USA }\end{array}$ \\
\hline b) No & $6(+2)$ & Australia, Columbia, Finland, (Israel), Japan, Mexico, South Korea, (Sweden) \\
\hline
\end{tabular}

Almost all countries tolerate that dual citizens participate politically at the same time in their country of origin and in the country of residence although only a minority seems to do so explicitly (see table 2.19). In most countries these issues have not reached political salience but in the Netherlands, South Korea, Algeria and Japan the right of dual nationals take political offices has been an issue of intensive public debate and in a quite a few other countries it has been controversially discussed, as well (see table 2.20). 


\begin{tabular}{|c|c|c|c|}
\hline Table 2.19 & \multicolumn{3}{|c|}{$\begin{array}{l}\text { Are dual citizens who participate in politics in the country of origin restricted in } \\
\text { their rights to participate in politics in the country of residence? }\end{array}$} \\
\hline \multicolumn{2}{|c|}{ All received answers } & 29 & \\
\hline \multicolumn{2}{|c|}{$\begin{array}{l}\text { a) It is de jure accepted that they } \\
\text { participate in both countries }\end{array}$} & $\begin{array}{c}4 \\
(+2) \\
\end{array}$ & $\begin{array}{l}\text { Brazil, Columbia, (Greece), Hungary, Ireland, } \\
\text { (Switzerland) }\end{array}$ \\
\hline \multicolumn{2}{|c|}{$\begin{array}{l}\text { b) They are not restricted because the } \\
\text { issue is not explicitly regulated (toler- } \\
\text { ance) }\end{array}$} & $\begin{array}{c}17 \\
(+2)\end{array}$ & $\begin{array}{l}\text { Algeria, Austria, Croatia, Estonia, Finland, } \\
\text { (Greece), Israel, Italy, Japan, Lebanon, Mexico, } \\
\text { Morocco, Netherlands, Poland, Slovakia, Slove- } \\
\text { nia, Sweden, (Switzerland), USA }\end{array}$ \\
\hline \multicolumn{2}{|c|}{$\begin{array}{l}\text { c) They are de jure restricted, but } \\
\text { there exist major/many exceptions }\end{array}$} & 1 & Denmark \\
\hline \multicolumn{2}{|c|}{$\begin{array}{l}\text { d) They are de jure restricted, but in } \\
\text { reality are not, because of no/minimal } \\
\text { controls }\end{array}$} & 4 & Australia, Luxembourg, Portugal, South Africa \\
\hline \multicolumn{2}{|c|}{$\begin{array}{l}\text { e) They are de jure and de facto re- } \\
\text { stricted, because of strict controls }\end{array}$} & 1 & South Korea \\
\hline
\end{tabular}

\begin{tabular}{|l|l|l|}
\hline Table 2.20 & Was the right of dual nationals to take political offices an issue of public controversy? \\
\hline
\end{tabular}

\begin{tabular}{|l|c|l|}
\hline All received answers & 32 & \\
\hline $\begin{array}{l}\text { a) } 1=\text { intensive } \\
\text { debate }\end{array}$ & 2 & Netherlands, South Korea, \\
\hline b) 2 & 2 & Algeria, Japan \\
\hline c) 3 & 6 & Australia, Finland, Hungary,Lithuania, Poland, Turkey \\
\hline d) 4 & $3(+3)$ & (Austria), Estonia, Latvia, Mexico, (Sweden), (USA) \\
\hline $\begin{array}{l}\text { e) } 5=\text { no public } \\
\text { debate }\end{array}$ & $\begin{array}{l}\text { (Austria), Brazil, Columbia, Croatia, Denmark, Greece, Ireland, } \\
(+3)\end{array}$ & $\begin{array}{l}\text { Israel, Italy, Lebanon, Luxembourg, Morocco, Portugal, Slova- } \\
\text { kia, South Africa, Spain, (Sweden), Switzerland, Ukraine, (USA) }\end{array}$ \\
\hline
\end{tabular}

Until now, we looked at the political salience and the specific regulations of dual citizenship. In the following two sections, we provide some information which feeds into the discussion of how to explain the trend towards a more liberal stance towards dual citizenship and we briefly address a notorious topic in the discussion about the consequences of dual citizenship: Security - for (the international system of) nation states and for individuals.

\section{Initiators and driving forces}

In the literature on dual citizenship we can discover two quite different approaches towards explaining the results of recent changes in the regulation of dual citizenship. On the one hand side, there are broad macro-explanations for the long-term trend towards more openness. Kivisto and Feist (2007: 107-110) list five reasons for the proliferation of dual citizenship: a) increased levels of migration, b) the reduced salience of concerns over diplomatic protection of citizens that accompanies the rise of concerns over human rights, c) 
the success of the woman's movement for gender equality, d) the shifting interests of immigrant sending countries and e) the dissolution of empires and nations. One the other hand, we have in-depth case-studies which provide detailed information about the actors and the processes of citizenship reforms in specific countries (e.g. the contributions in Faist 2007). With the following question about the main initiators or driving forces we tried to get some information which is actor-centered and more generalizable than single case-studies. The answers in the tables 2.21 to 2.23 reveal the relatively strong importance of emigrants/expatriates in the latest citizenship reforms with an impact on the acceptance of dual citizenship - mainly, but not only in migrant sending countries. Furthermore, the answers make clear that the governments are the main actors in the field of (dual) citizenship policy. ${ }^{12}$

\begin{tabular}{|l|c|l|}
\hline $\begin{array}{l}\text { Table } \\
2.21\end{array}$ & \multicolumn{3}{|l|}{$\begin{array}{l}\text { If there has been a successful or a failed attempt to accept/tolerate dual citizenship, } \\
\text { which actors have been the main initiator/driving forces in the last reform? (multiple } \\
\text { answers possible) }\end{array}$} \\
\hline a) The government & $\begin{array}{c}16 \\
(+1)\end{array}$ & $\begin{array}{l}\text { Estonia, Hungary, Israel, (Italy), Japan, Lebanon, Netherlands, } \\
\text { Poland, Portugal, Slovakia, Slovenia, South Africa, Spain, Swe- } \\
\text { den, Switzerland, Turkey, Ukraine }\end{array}$ \\
\hline b) Immigrant groups & $2(+3)$ & Luxembourg, Mexico, (Sweden), (Switzerland), (USA) \\
\hline $\begin{array}{l}\text { c) Liberal parties / } \\
\text { Human rights activ- } \\
\text { ists }\end{array}$ & $2(+3)$ & (Italy), Morocco, Portugal, (Switzerland), (USA) \\
\hline $\begin{array}{l}\text { d) Courts } \\
\text { e) Emigrant } \\
\text { groups/Expatriats }\end{array}$ & $9(+2)$ & $\begin{array}{l}\text { Columbia, Estonia, Hungary, (Italy), Lithuania, Morocco, Po- } \\
\text { land, Slovenia, Sweden, (Switzerland), Turkey }\end{array}$ \\
\hline $\begin{array}{l}\text { f) Foreign govern- } \\
\text { ments (indirectly, } \\
\text { through policies } \\
\text { affecting emigrants) }\end{array}$ & $3(+1)$ & Lebanon, Mexico, Slovenia, (Switzerland), (USA) \\
\hline $\begin{array}{l}\text { g) International/ } \\
\text { Supranational Or- } \\
\text { ganizations, e.g. the } \\
\text { European Union }\end{array}$ & $3(+1)$ & Mexico, Portugal, (Switzerland), Ukraine \\
\hline
\end{tabular}
have been pursued by the governments points to the limits of our method. Furthermore, we acknowledge that for a real understanding of the political processes we probably would have to disaggregate "the government". 


\begin{tabular}{|c|c|c|}
\hline $\begin{array}{l}\text { If there } 1 \\
\text { which ac }\end{array}$ & \multicolumn{2}{|c|}{$\begin{array}{l}\text { If there has been a successful or a failed attempt to accept/tolerate dual citizenship, } \\
\text { which actors have been the main initiator/driving forces in the second-last reform? }\end{array}$} \\
\hline a) The government & $\begin{array}{c}14 \\
(+4)\end{array}$ & $\begin{array}{l}\text { Australia, (Austria), Estonia, Germany, Hungary, (Israel), (Italy), } \\
\text { Japan, Latvia, Netherlands, Portugal, Slovakia, Slovenia, South } \\
\text { Africa, Spain, (Switzerland), Turkey, Ukraine }\end{array}$ \\
\hline b) Immigrant groups & $2(+1)$ & Australia, Mexico, (Sweden) \\
\hline $\begin{array}{l}\text { c) Liberal parties / } \\
\text { Human rights activ- } \\
\text { ists }\end{array}$ & $3(+3)$ & $\begin{array}{l}\text { (Germany), (Italy), Morocco, Slovenia, South Africa, (Switzer- } \\
\text { land) }\end{array}$ \\
\hline d) Courts & $1(+2)$ & (Israel), (Italy), Japan, \\
\hline $\begin{array}{l}\text { e) Emigrant } \\
\text { groups/Expatriats }\end{array}$ & $6(+2)$ & $\begin{array}{l}\text { Australia, Estonia, Hungary, Lithuania, Portugal, (Sweden), } \\
\text { (Switzerland), Turkey }\end{array}$ \\
\hline $\begin{array}{l}\text { f) Foreign govern- } \\
\text { ments (indirectly, } \\
\text { through policies } \\
\text { affecting emigrants) }\end{array}$ & 4 & Australia, Lithuania, Mexico, Morocco \\
\hline $\begin{array}{l}\text { g) Interna- } \\
\text { tional/Supranational } \\
\text { Organizations, e.g. } \\
\text { the European Union }\end{array}$ & 4 & Mexico, Morocco, Slovenia, Ukraine \\
\hline
\end{tabular}

\begin{tabular}{|l|c|l|}
\hline $\begin{array}{l}\text { Table } \\
2.23\end{array}$ & \multicolumn{3}{|c|}{$\begin{array}{l}\text { If there has been a successful or a failed attempt to accept/tolerate dual citizenship, } \\
\text { which actors have been the main initiator/driving forces in the failed reform attempt? }\end{array}$} \\
\hline a) The government & $5(+3)$ & $\begin{array}{l}\text { (Germany), Japan, Netherlands, Poland, Portugal, (Sweden), } \\
\text { (Switzerland), Ukraine }\end{array}$ \\
\hline b) Immigrant groups & $3(+1)$ & Hungary, Mexico, Morocco, (Switzerland) \\
\hline $\begin{array}{l}\text { c) Liberal parties / } \\
\text { Human rights activ- } \\
\text { ists }\end{array}$ & $2(+3)$ & (Austria), (Germany), (Italy), Lebanon, Morocco \\
\hline d) Courts & 2 & Japan, Lithuania \\
\hline $\begin{array}{l}\text { e) Emigrant } \\
\text { groups/Expatriats }\end{array}$ & 4 & Lebanon, Lithuania, Poland, South Korea \\
\hline $\begin{array}{l}\text { f) Foreign govern- } \\
\text { ments (indirectly, } \\
\text { through policies } \\
\text { affecting emigrants) }\end{array}$ & 1 & Mexico \\
\hline $\begin{array}{l}\text { g) Interna- } \\
\text { tional/Supranational } \\
\begin{array}{l}\text { Organizations, e.g. } \\
\text { the European Union }\end{array}\end{array}$ & 0 & \\
\hline
\end{tabular}




\section{Security consequences for the international system and for individuals}

Security issues were predominant at the beginning of the debates and regulations of dual citizenship and lead to norms and regulations which tried to avoid dual citizenship on the national and international level. The rising acceptance of dual citizenship has been (partly) explained by the decline of conscription and the rise of professional militaries (Triadafilopoulos 2007) and by declining salience of concerns over diplomatic protection Kivisto and Feist (2007: 108). The results of our inquiry (tables 2.24 and 2.25) do confirm these general assumptions but also point to some exceptions. In the international conflicts that Morocco experienced concerning dual citizens both issues showed up: military service and diplomatic protection.

\begin{tabular}{|l|c|l|}
\hline $\begin{array}{l}\text { Table } \\
2.24\end{array}$ & \multicolumn{3}{|l|}{$\begin{array}{l}\text { Has the issue of military service of dual citizens been an issue of international con- } \\
\text { flicts and/or of international treaties with other countries since 1990? }\end{array}$} \\
\hline $\begin{array}{l}\text { a) Serious interna- } \\
\text { tional conflict }\end{array}$ & 1 & Morocco \\
\hline $\begin{array}{l}\text { b) International } \\
\text { tension }\end{array}$ & $3(+1)$ & (Israel), Mexico, Morocco, South Africa \\
\hline $\begin{array}{l}\text { c) International } \\
\text { treaty }\end{array}$ & $7(+4)$ & $\begin{array}{l}\text { Denmark, Finland, (Greece), Hungary, (Italy), Mexico, Mo- } \\
\text { rocco, (Sweden), (Switzerland), Turkey, Ukraine }\end{array}$ \\
\hline $\begin{array}{l}\text { d) No conflicts, } \\
\text { tensions and treaties }\end{array}$ & $7(+1)$ & $\begin{array}{l}\text { Algeria, Croatia, Ireland, Japan, Luxembourg, Slovenia, South } \\
\text { Korea, (Switzerland) }\end{array}$ \\
\hline e) I do not know & $2(+1)$ & Poland, (Switzerland), USA \\
\hline
\end{tabular}

\begin{tabular}{|l|c|l|}
\hline Table 2.25 & \multicolumn{2}{|c|}{$\begin{array}{l}\text { Has the issue of diplomatic protection of dual citizens been an issue of international } \\
\text { conflict since 1990? }\end{array}$} \\
\hline $\begin{array}{l}\text { Major international } \\
\text { conflict 1 => 5 No } \\
\text { international conflict }\end{array}$ & 33 & \\
\hline a) 1 & 0 & \\
\hline b) 2 & 1 & Morocco \\
\hline c) 3 & $1(+1)$ & Croatia, (USA) \\
\hline d) 4 & $5(+1)$ & Denmark, Mexico, Netherlands, South Africa, Sweden, (USA) \\
\hline & 25 & $\begin{array}{l}\text { Algeria, Australia, Austria, Columbia, Estonia, Finland, Ger- } \\
\text { many, Greece, Hungary, Ireland, Italy, Japan, Latvia, Lebanon, } \\
\text { Lithuania, Luxembourg, Poland, Portugal, Slovakia, Slovenia, } \\
\text { South Korea, Spain, Switzerland, Turkey, Ukraine }\end{array}$ \\
\hline e) 5 &
\end{tabular}

It has been suggested that the new securitization of immigration and citizenship since $9 / 11$ does not lead to a rejection of dual citizenship but to a cynic embracement of dual citizenship by those who advocate tough measures against immigrants (Triadafilopoulos 2007: 37 with reference to Nyers). Dual citizens can more easily be stripped of their nationality by countries which perceive them as threats since they do not end up with having no na- 
tionality (Macklin 2007). Our review shows that this line of argumentation has not been taken up in many countries (table 2.26). Those experts who have reported these kinds of argumentation in the discourse on dual citizenship have observed it primarily in argumentations by those who argue against the use of citizenship regulations as policy measures in the fight against terrorists and criminals. This leads to rather paradoxical lines of argumentation. In the Dutch debate, for example, D66, the most liberal party in respect to immigration and dual citizenship, used this argument in their attempts to stop a government proposal that aimed at reducing dual citizenship. D66 argued that the reduction of dual citizenship would make it impossible to banish immigrant terrorists. ${ }^{13}$

The fact that our Dutch expert reported that this line of argumentation has been used as an argument against dual citizenship in the Netherlands (see table 2.6) points either to the fact that in recent times advocates of liberal immigration and citizenship policies have become aware of the potential danger of dual citizens for being expelled. It probably points more to the fact that for both conservatives and liberals, the link between dual citizenship and security becomes very ambivalent. Conservatives/communitarians, which care more about the security of the native community, might be tempted by the opportunity to expel and denaturalize unwanted immigrants. Nevertheless, their general belief that loyalties cannot be divided makes them reluctant in perusing this strategy. Progressives and liberals, who put more emphasis on the security of individuals/migrants, usually do not want to argue as opportunistic as D66 and ignore the potential negative side-effects of dual citizenship for the security of dual citizens.

\begin{tabular}{|l|c|l|}
\hline $\begin{array}{l}\text { Table } \\
2.26\end{array}$ & \multicolumn{3}{|l|}{$\begin{array}{l}\text { Has the point that it might be easier for states to denaturalise a citizen who has dual } \\
\text { citizenship, played a role in public debates on dual citizenship or in governmental } \\
\text { considerations for changing (the application of) citizenship regulations? }\end{array}$} \\
\hline All received answers & 33 & \\
\hline $\begin{array}{l}\text { a) Yes, as an argu- } \\
\text { ment for dual citizen- } \\
\text { ship }\end{array}$ & 1 & Morocco \\
\hline $\begin{array}{l}\text { b) Yes, as an argu- } \\
\text { ment against dual } \\
\text { citizenship }\end{array}$ & $\begin{array}{c}5 \\
(+1)\end{array}$ & Mexico, Netherlands, Slovenia, (Switzerland), Ukraine, USA \\
\hline & $\begin{array}{l}26 \\
(+1)\end{array}$ & $\begin{array}{l}\text { Algeria, Australia, Austria, Brazil, Columbia, Croatia, Estonia, } \\
\text { Finland, Germany, Greece, Hungary, Ireland, Israel, Italy, Japan, } \\
\text { Latvia, Lithuania, Luxembourg, Poland, Portugal, Slovakia, South } \\
\text { Africa, South Korea, Spain, Sweden, (Switzerland), Turkey }\end{array}$ \\
\hline
\end{tabular}




\subsection{Summary and Conclusion}

Our data reveals the high political salience of citizenship regulations in many countries and the fact that the acceptance of dual citizenship is often a very controversial aspect of citizenship reforms. In line with the data in the first part of the paper, our data shows a steady trend towards broader acceptance of dual citizenship. Furthermore, we discover a trend towards more symmetric regulations of dual citizenship insofar that emigrants and immigrants are treated similar. Although this is mainly due to the fact that dual citizenship is facilitated for emigrants we do not interpret this as a re-ethnicization of citizenship but as a trend towards an expansive and non-exclusive notion of citizenship. Contrary to many normative theorists, most countries do not apply any restrictions for dual citizens in respect to political participation and in respect to taking political offices. Finally, our data does not confirm any "securitization" discourses. Both, the traditional/conservative fear that dual citizens might produce military or diplomatic conflicts between states and the liberal/critical warning that dual citizenship might be used for expelling and denationalizing migrants, which are perceived as threats to the host society, have proven unwarranted (so far).

We would like to end with a cautionary note. The use of an expert survey made it possible to go beyond case studies and beyond the narrow data sets which primarily contain legal information about the current state of regulations but it comes with a price in respect to the reliability of our data. The inconsistencies between the answers of the experts which have filled in the questionnaire for the same country made this very clear. Nevertheless, we think that the survey provides an accurate picture of general tendencies and trends. For those who need more specific information about single countries we provide the list of our country experts and an extensive list of further literature.

\section{List of References}

Aleinikoff, T. A. \& Klusmeyer, D. (2001): Citizenship Today. Global Perspectives and Practices. Washington, D.C.: Carnegie Endowment for International Peace.

Aleinikoff, T. A. \& Klusmeyer, D. (2002): Citizenship Policies for an Age of Migration. : Washington, DC: Carnegie Endowments for International Peace and Migration Policy Institute.

Bauböck, R. (1994): Transnational Citizenship. Membership and Rights in International Migration. Hants: Edward Elgar Publishing Limited.

Betts, K. (2002): Democracy and Dual Citizenship. In: People and Place, 10, 1, 57-70.

Blatter, Joachim (2008): Dual citizenship and democracy. Working paper 1/08 of the Instiute of Political Science. Lucerne: University of Lucerne. 
Bloemraad, I. (2004): Who claims dual citizenship? The limits of Postnationalism, the Possibilities of Transnationalism, and the Persistence of Traditional Citizenship. In: International Migration Review, 38, 2, 389-426.

Boll, A.M (2007): Multiple Nationality and International Law. Leiden/Boston: Martinus Nijhoff Publishers; country information is provided in the appendix, pp. 309-566.

Brondsted Sejersen, T. (2008): "I Vow Thee My Countries" - The Expans0on of Dual Citizenship in the $21^{\text {st }}$ Century. In: International Migration Review, 42, 3 (Autumn 2008), 523-549.

Cain, B. E. \& Doherty, B. J. (2006): The Impact of Dual Nationality on Political participation. In: Taeku, L., Ramakrishnan, K. S., Ramirez, R. \& eds. (Hg.): Transforming Politics, Transformin America: The Political and Civic Incorporation of Immigrants in the United States. Charlottsville/London: University of Virginia Press, 89-105.

Chopin, Isabelle (2006): Administrative Practice in the Acquisition of nationality, in: Bauböck et al. (ed.): Acquisition and Loss of Nationality. Policies and Trends in 15 European States. Volume 1: Comparative Analyses. Amsterdam: Amsterdam University Press, 221-268 [especially pages: 251-255]

Escobar, C. (2004): Dual Nationality and Political Participation: Migrants in the Interplay of United States and Colombian Politics. In: Latino Studies.2, 45-69.

Escobar, C. (2006): Dual Citizenship and Political Participation: Migrants in the Interplay of United States and Colombian Politics. In: Oboler, S. (Hg.): Latinos and citizenship: the dilemma of belonging. New York: Palgrave Macmillan, 113-141.

Faist, T. \& Kivisto, P. (2007): Dual Citizenship in Global Perspective. From Unitary to Multiple Citizenship. New York: Palgrave Macmillan.

Faist, T. (2007): Dual Citizenship in Europe. From Nationhood to Social Integration. Aldershot: Ashgate.

Groot, Gerard-René and Maarten Vink (2008): Meervoudige nationaliteit in Europees perspectief. Een landenverglijkend overzicht. Den Haag: Adviescommissie voor Vreemdelingenzaaken.

Hansen, R. \& Weil, P. (2002): Introduction: Dual Citizenship in a Changed World: Immigration, Gender and Social Rights. In: Hansen, R. \& Weil, P.(Hg.): Dual nationality, social rights and federal citizenship in the US and Europe: the reinvention of citizenship. Oxford/New York: Berghahn Books, 1-15.

Howard, Marc M. (2005): Variation in Dual Citizenship Policies in the Countries of the EU, in: IMR Vol. 39, p. 697-720 [especially p. 709].

Itzigsohn, J. (2007): Migration and Transnational Citizenship in Latin America: The Case of Mexico and the Dominican Republic. In: Faist T. \& Kivisto, P. (Hg.) Dual Citizenship in Global Perspective. From Unitary to Multiple Citizenship. New York: Palgrave Macmillan, 113-134.

Jones-Carrera, M. (1998): Between Two Nations: The Political Predicament of Latinos in New York City. Ithaca: Cornell University Press.

Jones-Carrera, M. (2001): Under Two Flags: Dual Nationality in Latin America and its Consequences for Naturalization in the United States. In: International Migration Review, 35, 997-1029 [table on p. 999]

Kalekin-Fishman, D. and P. Pitkänen (eds.) (2007): Multiple Citizenship as a Challenge to European Nation-States. Rotterdam/Taipei: Sense Publishers.

Kivisto, P and Th. Faist (2007): Citizenship. Discourse, Theory, and Transnational Prospects. Malden/Oxford: Blackwell. 
Kleger, H. (ed.) (1997): Transnationale Staatsbürgerschaft. Frankfurt/New York: Campus.

Martin, D. A. \& Hailbronner, K. (2003): Rights and Duties of Dual Nationals. Evolution and Prospects. The Hague: Kluwer Law International.

Mazzolori, F. (2005): Determinants of Naturalization: The Role of Dual Citizenship Laws. The Center of Comparative Immigration Studies. University of California, San Diego: Working Paper 117.

Neuman, G. L. (1994): Citizenship Panel. Principal Paper. Justifying U.S. Naturalization Policies. In: Virginia Journal of International Law, 35, 237-278.

Renshon, S. (2005): The 50\% American. Immigration and National Identity in an Age of Terror. Washington/DC: Georgetown University Press; list of countries which accept dual citizenship is provided in the appendix, pp. 255-260.

Schröter, Y. M., Mengelkamp, C. \& Jäger R. S. (2005): Doppelte Staatsbürgerschaft - ein gesellschaftlicher Diskurs über Mehrstaatigkeit. Landau: Verlag Empirischer Pädagogik.

Spiro, P. J. (1997): Dual nationality and the meaning of Citizenship. In: Emory Law Journal, 46, 4, 1411-1485.

Spiro, P. J. (2006): Perfecting Political Diaspora. In: New York University Law Review, $81,30,101-125$.

Staton, Jeffrey K., Jackson, Robert and Canache, Damarys, (2007): Costly Citizenship? Dual Nationality Institutions, Naturalization, and Political Connectedness (June 19,2007). Available at SSRN: http/ssm.com/abstract=995569

United States Office of Personnel Management, Investigations Service (2001): Citizenship Laws of the World. <http://www.opm.gov/extra/investigati/IS-o1-pfd>

Weil, P. (2001): Access to Citizenship: A comparison of Twenty-Five Nationality Laws. In: Aleinikoff, Th. and D. B. Klusmeyer (eds).: Citizenship Today: Global Perspectives and Practices. Washington/DC: Brookings Institution Press, pp 17-35 [especially p. 22]. 


\section{List of Experts}

\begin{tabular}{|c|c|c|c|}
\hline Country & Name & E-mail & Institution \\
\hline Algeria & $\begin{array}{l}\text { George } \\
\text { Joffé }\end{array}$ & giris@msn.com & $\begin{array}{l}\text { Centre of International Stud- } \\
\text { ies, University of Cambridge; } \\
\text { Kings College, London Uni- } \\
\text { versity; Royal United Services } \\
\text { Institute / UK }\end{array}$ \\
\hline Australia & $\begin{array}{l}\text { Gianni } \\
\text { Zappala }\end{array}$ & $\begin{array}{l}\text { gianniz } \\
\text { @orfeusresearch.com.au }\end{array}$ & $\begin{array}{l}\text { Studied Economics \& Politics; } \\
\text { Director of Orfeus Research } \\
\text { (Consultancy)\& University of } \\
\text { Sydney / Australia }\end{array}$ \\
\hline Austria & $\begin{array}{l}\text { Dilek } \\
\text { Çinar }\end{array}$ & dilek.cinar@boun.edu.tr & $\begin{array}{l}\text { Department of Political Sci- } \\
\text { ence and International Rela- } \\
\text { tions, Boğaziçi University / } \\
\text { Turkey }\end{array}$ \\
\hline Austria & $\begin{array}{l}\text { Claus } \\
\text { Hofhansel }\end{array}$ & claus3@cox.net & $\begin{array}{l}\text { Political Science, the Minda de } \\
\text { Gunzburg Center for European } \\
\text { Studies at Harvard University / } \\
\text { USA }\end{array}$ \\
\hline Brazil & $\begin{array}{l}\text { Charles P. } \\
\text { Gomes }\end{array}$ & cgomes@rb.gov.br & $\begin{array}{l}\text { researcher at Fundaçao Casa } \\
\text { de Rui Barbosa / Brazil }\end{array}$ \\
\hline Canada & $\begin{array}{l}\text { Irene } \\
\text { Bloemraad }\end{array}$ & bloemr@berkeley.edu & $\begin{array}{l}\text { Department of Sociology, UC } \\
\text { Berkeley / USA }\end{array}$ \\
\hline Canada & $\begin{array}{l}\text { Donald } \\
\text { Galloway }\end{array}$ & galloway@uvic.ca & $\begin{array}{l}\text { Faculty of Law, University of } \\
\text { Victoria, BC / Canada }\end{array}$ \\
\hline Columbia & $\begin{array}{l}\text { Christina } \\
\text { Escobar }\end{array}$ & cescobar@Princeton.edu & $\begin{array}{l}\text { Research Scholar, Sociology } \\
\text { and the Center for Migration } \\
\text { and Development, Princeton } \\
\text { University / USA }\end{array}$ \\
\hline Croatia & $\begin{array}{l}\text { Iris } \\
\text { Goldner Lang }\end{array}$ & igoldner@pravo.hr & $\begin{array}{l}\text { Faculty of Law, University of } \\
\text { Zagreb / Croatia }\end{array}$ \\
\hline Denmark & $\begin{array}{l}\text { Eva } \\
\text { Ersbøll }\end{array}$ & eer@humanrights.dk & $\begin{array}{l}\text { The Danish Institute for Hu- } \\
\text { man Rights / Denmark }\end{array}$ \\
\hline Estonia & $\begin{array}{l}\text { Priit } \\
\text { Järve }\end{array}$ & jaerve@yahoo.com & Independent Researcher \\
\hline Finland & $\begin{array}{l}\text { Pirkko } \\
\text { Pitkänen }\end{array}$ & pirkko.pitkanen@joensuu.fi & $\begin{array}{l}\text { Intercultural Education, Uni- } \\
\text { versity of Joensuu; Education, } \\
\text { University of Tampere; Educa- } \\
\text { tional Philosophy, University } \\
\text { of Oulu / Finland }\end{array}$ \\
\hline Germany & $\begin{array}{l}\text { Jürgen } \\
\text { Gerdes }\end{array}$ & jgerdes2@uni-bielefeld.de & $\begin{array}{l}\text { Research Fellow at COMCAD } \\
\text { at the Faculty of Sociology, } \\
\text { Bielefeld University / Ger- } \\
\text { many }\end{array}$ \\
\hline Germany & $\begin{array}{l}\text { Claus } \\
\text { Hofhansel }\end{array}$ & claus3@cox.net & $\begin{array}{l}\text { Political Science, the Minda de } \\
\text { Gunzburg Center for European } \\
\text { Studies at Harvard University / } \\
\text { USA }\end{array}$ \\
\hline Greece & $\begin{array}{l}\text { Dimitris } \\
\text { Christopoulos }\end{array}$ & christopoulos@synigoros.gr & $\begin{array}{l}\text { Department of Political Sci- } \\
\text { ence and History, Panteion } \\
\text { University of Athens / Greece }\end{array}$ \\
\hline Greece & $\begin{array}{l}\text { Konstantinos } \\
\text { Tsitselikis }\end{array}$ & kt@uom.gr & $\begin{array}{l}\text { Department of Balkan, Slavic } \\
\text { and Oriental studies, Univer- } \\
\text { sity of Macedonia / Greece }\end{array}$ \\
\hline
\end{tabular}




\begin{tabular}{|c|c|c|c|}
\hline Hungary & $\begin{array}{l}\text { Judith } \\
\text { Toth }\end{array}$ & skula@juris.u-szeged.hu & $\begin{array}{l}\text { Faculty of Law, University of } \\
\text { Szeged / Hungary }\end{array}$ \\
\hline Ireland & $\begin{array}{l}\text { John } \\
\text { Handoll }\end{array}$ & john.handoll@williamfry.ie & $\begin{array}{l}\text { William Fry Solicitors / Ire- } \\
\text { land }\end{array}$ \\
\hline Israel & $\begin{array}{l}\text { Sara } \\
\text { Helman }\end{array}$ & sarith@bgu.ac.il & $\begin{array}{l}\text { Department of Sociology, Ben } \\
\text { Gurion University / Israel }\end{array}$ \\
\hline Israel & $\begin{array}{l}\text { Devorah } \\
\text { Kalekin- } \\
\text { Fishman }\end{array}$ & dkalekin@construct.haifa.ac.il & $\begin{array}{l}\text { Faculty of Education, Univer- } \\
\text { sity of Haifa / Isreal }\end{array}$ \\
\hline Italy & $\begin{array}{l}\text { Marta } \\
\text { Arena }\end{array}$ & marta_arena_tos@yahoo.fr & $\begin{array}{l}\text { The International and Euro- } \\
\text { pean Forum of Migration Re- } \\
\text { search (FIERI) / Italy }\end{array}$ \\
\hline Italy & $\begin{array}{l}\text { Bruno } \\
\text { Nascimbene }\end{array}$ & info@nascimbene.com & $\begin{array}{l}\text { Faculty of Law, University of } \\
\text { Milan / Italy }\end{array}$ \\
\hline Japan & $\begin{array}{l}\text { John } \\
\text { Clammer }\end{array}$ & clammer@hq.unu.edu & $\begin{array}{l}\text { Comparative Sociology and } \\
\text { Asian Studies at Sophia Uni- } \\
\text { versity/ United Nations Uni- } \\
\text { versity, Tokyo / Japan }\end{array}$ \\
\hline Latvia & $\begin{array}{l}\text { Kristine } \\
\text { Kruma }\end{array}$ & $\underline{\text { Kristine.Kruma@rgsl.edu.lv }}$ & $\begin{array}{l}\text { Riga Graduate School of Law, } \\
\text { Riga / Latvia }\end{array}$ \\
\hline Lebanon & $\begin{array}{l}\text { Guita } \\
\text { Hourani and } \\
\text { Eugene } \\
\text { Dabbous }\end{array}$ & $\begin{array}{l}\text { ghourani@ndu.edu.lb and } \\
\underline{\text { sdabbous@ @du.edu.lb }}\end{array}$ & $\begin{array}{l}\text { Lebanese Emigration Research } \\
\text { Center I Faculty of Political } \\
\text { Science, Public Administration } \\
\text { \& Diplomacy, Notre Dame / } \\
\text { Lebanon }\end{array}$ \\
\hline Lithuania & $\begin{array}{l}\text { Kristine } \\
\text { Kruma }\end{array}$ & $\underline{\text { Kristine.Kruma@rgsl.edu.lv }}$ & $\begin{array}{l}\text { Riga Graduate School of Law, } \\
\text { Riga / Latvia }\end{array}$ \\
\hline Luxembourg & $\begin{array}{l}\text { Serge } \\
\text { Kollwetter }\end{array}$ & serge.kollwelter@education.lu & $\begin{array}{l}\text { Ministry of Education / Lu- } \\
\text { xemburg }\end{array}$ \\
\hline Malta & $\begin{array}{l}\text { Eugene } \\
\text { Buttigieg }\end{array}$ & eugene.buttigieg@um.edu.mt & $\begin{array}{l}\text { Department of European and } \\
\text { Comparative Law, University } \\
\text { of Malta / Malta; Visiting } \\
\text { Fellow in European Law at the } \\
\text { British Institute of Interna- } \\
\text { tional and Comparative Law, } \\
\text { London / UK }\end{array}$ \\
\hline Mexico & $\begin{array}{l}\text { Jorge A. } \\
\text { Vargas }\end{array}$ & mexlaw@sandiego.edu & $\begin{array}{l}\text { Faculty of Law, University } \\
\text { San Diego, USA }\end{array}$ \\
\hline Morocco & $\begin{array}{l}\text { Naima } \\
\text { Baba }\end{array}$ & naima@justice.com & $\begin{array}{l}\text { Faculty of Law, Economics } \\
\text { and Social Sciences, Univer- } \\
\text { sity Hassan II / Morocco }\end{array}$ \\
\hline Netherlands & $\begin{array}{l}\text { Gerard-Rene } \\
\text { de Groot }\end{array}$ & r.degroot@pr.unimaas.nl & $\begin{array}{l}\text { Faculty of Law; University of } \\
\text { Maastricht / The Netherlands }\end{array}$ \\
\hline Poland & $\begin{array}{l}\text { Piotr Krzysz- } \\
\text { tof } \\
\text { Koryś }\end{array}$ & pkorys@wne.uw.edu.pl & $\begin{array}{l}\text { Department of Economic His- } \\
\text { tory, Faculty of Economic } \\
\text { Sciences, University of War- } \\
\text { saw / Poland }\end{array}$ \\
\hline Portugal & $\begin{array}{l}\text { Maria da } \\
\text { Conceição } \\
\text { Pereira } \\
\text { Ramos }\end{array}$ & cramos@fep.up.pt & $\begin{array}{l}\text { Department of Economics and } \\
\text { Public Financing, University } \\
\text { of Porto / Portugal }\end{array}$ \\
\hline Slovakia & $\begin{array}{l}\text { Tibor } \\
\text { Papp }\end{array}$ & tibor@papp.sk & Independent researcher \\
\hline Slovenia & $\begin{array}{l}\text { Felicita } \\
\text { Medved }\end{array}$ & felicita_mail@yahoo.com & Independent researcher \\
\hline South Africa & Jonathan & jonathan.klaaren@wits.ac.za & University of Witwatersrand, \\
\hline
\end{tabular}




\begin{tabular}{|c|c|c|c|}
\hline & Klaaren & & $\begin{array}{l}\text { Johannesburg / } \\
\text { South Africa }\end{array}$ \\
\hline South Korea & $\begin{array}{l}\text { Chulwoo } \\
\text { Lee }\end{array}$ & chulwoo.lee@yonsei.ac.kr & $\begin{array}{l}\text { College of Law, Yonsei Uni- } \\
\text { versity / Republic of Korea }\end{array}$ \\
\hline Spain & $\begin{array}{l}\text { Francisco } \\
\text { Javier Moreno } \\
\text { Fuentes }\end{array}$ & javier.moreno@iesam.csic.es & $\begin{array}{l}\text { Political Science, Madrid - } \\
\text { researcher CSIC / Spain }\end{array}$ \\
\hline Sweden & $\begin{array}{l}\text { Henrik } \\
\text { Bernitz }\end{array}$ & henrik.bernitz@jklgroup.com & JKL Gothenburg / Sweden \\
\hline Sweden & $\begin{array}{l}\text { Per } \\
\text { Gustafson }\end{array}$ & per.gustafson@ibf.uu.se & $\begin{array}{l}\text { Institute for Housing and Ur- } \\
\text { ban Research, University of } \\
\text { Uppsala / Sweden }\end{array}$ \\
\hline Switzerland & $\begin{array}{l}\text { Gianni } \\
\text { D'Amato }\end{array}$ & gianni.damato@unine.ch & $\begin{array}{l}\text { Migration and Citizenship } \\
\text { Studies, Université de Neuchâ- } \\
\text { tel; Director of the Swiss Fo- } \\
\text { rum for Migration and Popula- } \\
\text { tion Studies, Neuchâtel / Swit- } \\
\text { zerland }\end{array}$ \\
\hline Switzerland & $\begin{array}{l}\text { Claus } \\
\text { Hofhansel }\end{array}$ & claus3@cox.net & $\begin{array}{l}\text { Political Science, the Minda de } \\
\text { Gunzburg Center for European } \\
\text { Studies at Harvard University / } \\
\text { USA }\end{array}$ \\
\hline Switzerland & $\begin{array}{l}\text { Brigitte } \\
\text { Studer }\end{array}$ & brigitte.studer@hist.unibe.ch & $\begin{array}{l}\text { Department for History, Uni- } \\
\text { versity of Bern / Switzerland }\end{array}$ \\
\hline Turkey & $\begin{array}{l}\text { Zeynep } \\
\text { Kadirbeyoglu }\end{array}$ & $\begin{array}{l}\text { zeynep.kadirbeyoglu } \\
\text { @ mail.mcgill.ca }\end{array}$ & McGill University / Canada \\
\hline Ukraine & $\begin{array}{l}\text { Oxana } \\
\text { Shevel }\end{array}$ & oxana.shevel@tufts.edu & $\begin{array}{l}\text { Department of Political Sci- } \\
\text { ence, Tufts University / USA }\end{array}$ \\
\hline USA & $\begin{array}{l}\text { Michael Jones } \\
\text { Correa }\end{array}$ & mj64@cornell.edu & $\begin{array}{l}\text { Government, Cornell Univer- } \\
\text { sity / USA }\end{array}$ \\
\hline USA & $\begin{array}{l}\text { Susan F. } \\
\text { Martin }\end{array}$ & martinsf@georgetown.edu & $\begin{array}{l}\text { Institute for the Study of Inter- } \\
\text { national Migration (ISIM), } \\
\text { Georgetown University / USA }\end{array}$ \\
\hline
\end{tabular}




\section{List of Further Literature (partly provided by our experts)}

Abou Dib, B. (2001). The Lebanese Nationality. Second Edition. Lebanon: Sader Legal Publications. [in Arabic]

Aleinikoff, T. A. \& D. Klusmeyer (2000) (eds.). From migrants to citizens. Membership in a changing world. Washington: Carnegie Endowment for International Peace.

Aleinikoff, T. A. (2000). Between Principles and Politics. US Citizenship Policy. In: Aleinikoff, T. A. \& D. Klusmeyer (eds.), From migrants to citizens. Membership in a changing world. Washington: Carnegie Endowment for International Peace, 119-174.

Aleinikoff, T. A. \& D. Klusmeyer (2001) (eds.). Citizenship Today. Global Perspectives and Practices. Washington, D.C.: Carnegie Endowment for International Peace.

Aleinikoff, T. A. \& D. Klusmeyer (2001). Plural Nationality: Facing the Future in a Migratory World. In: Aleinikoff, T. A. \& D. Klusmeyer (eds.), Citizenship Today. Global Perspectives and Practices. Washington, D.C.: Carnegie Endowment for International Peace, 63- 88.

Aleinikoff, T. A. \& D. Klusmeyer (2002) (eds.). Citizenship policies for an age of migration. Washington, D.C.: Carnegie Endowment for International Peace.

Aleinikoff, T. A. \& D. Klusmeyer (2002). Managing Dual Nationality. In: Aleinikoff, T. A. \& D. Klusmeyer (eds.), Citizenship policies for an age of migration. Washington, D.C.: Carnegie Endowment for International Peace, 22-41.

Ancelovici, M. \& D. Dupuis (1998). Interview with Professor Charles Taylor. Citizenship Studies 2(2): 247-256.

Arena, M., Nascimbene, B. \& G. Zincone (2006). Italy. In: Bauböck, R. et al. (eds.), Acquisition and Loss of Nationality. Policies and Trends in 15 European States. Volume 2: Country Analyses. Amsterdam: Amsterdam University Press, 329-366.

Argast, R. (2004). Hat das Gemeindebürgerrecht ausgedient? terra cognita, einbürgern, Schweizerische Zeitschrift zu Integration und Migration 4: 52-55.

Baehr, P. (2001). Changing Sovereigns: Citizenship and Democracy in Hong Kong. Citizenship Studies 5 (2): 101-102.

Baganha, M. I. \& C. Urbano de Sousa (2006). Portugal. In: Bauböck, R. et al. (eds.), Acquisition and Loss of Nationality. Policies and Trends in 15 European States. Volume 2: Country Analyses. Amsterdam: Amsterdam University Press, 435-476.

Baltsiotis, L. (2004). The citizenship during the cold war. In: Tsapogas, M. \& D. Christopoulos (eds.), The rights in Greece (1953-2003). Athens: Kastaniotis, 81-97. [in Greek]

Baltsiotis, L. (2004). Citizenship and naturalisation in Greece of migration. Contradictions of a dead end policy. In: Christopoulos, D. and M. Pavlou (eds.), Greece of immigration. Social participation, rights and quality of being citizen. Athens: Kritiki/KEMO, 303-337. [in Greek]

Barrington, L.W. (2000). Understanding Citizenship Policy in the Baltic States. In: Aleinikoff, T. A. \& D. Klusmeyer, From migrants to citizens. Membership in a changing world. Washington: Carnegie Endowment for International Peace, 253-304.

Barsová, A. (2007). Czech citizenship legislation between past and future. In: Bauböck, R. , Perching, B. \& W. Sievers (eds.), Citizenship Policies in the New Europe. Amsterdam: Amsterdam University Press, 163-184.

Bauböck, R. (1994). Transnational Citizenship. Aldershot \& Brookfield: Edward Elgar.

Bauböck, R. (1999). Recombinant Citizenship. IHS Vienna: Political Science Series No. 67.

Bauböck, R. (2001). Cultural Citizenship, Minority Rights, and Self-Government. In: Aleinikoff, T. A. \& D. Klusmeyer (eds.), Citizenship Today. Global Perspectives and Practices. Washington, D.C.: Carnegie Endowment for International Peace, 319-348.

Bauböck, R. (2003). Reinventing Urban Citizenship. Citizenship Studies. 7(2): 139-160.

Bauböck, R. (2005). Citizenship policies: international, state, migrant and democratic perspectives. Global Migration Perspectives 19. January 2005.

Bauböck, R. (2005). Expansive Citizenship-Voting beyond Territory and Membership. PS: Political Science and Politics 38(4): 683-689.

Bauböck, R. et al. (2007) (eds.). Acquisition and Loss of Nationality. Policies and Trends in 15 European States. Volume 1: Comparative Analyses. Amsterdam: Amsterdam University Press.

Bauböck, R. et al. (2007) (eds.). Acquisition and Loss of Nationality. Policies and Trends in 15 European States. Volume 2: Country Analyses. Amsterdam: Amsterdam University Press. 
Bauböck, R. (2007). Stakeholder Citizenship and Transnational Political Participation: A normative evaluation of external voting. Fordham Law Review 75(5).

Bauböck, R. (2007). The Trade-off between Transnational Citizenship and Political Autonomy. In: Faist, T. \& P. Kivisto (eds.), Dual Citizenship in Global Perspective. From Unitary to Multiple Citizenship. Basingstoke: Palgrave Macmillan, 69-91.

Bauböck, R. (2007). Why European Citizenship? Normative Approaches to Supranational Union. Theoretical Inquiries in Law 8(2).

Bauböck, R. et al. (2007). Introduction. In: Bauböck, R. et al. (eds.), Acquisition and Loss of Nationality. Policies and Trends in 15 European States. Volume 1: Comparative Analyses. Amsterdam: Amsterdam University Press, pp. 15-34.

Bauböck, R. \& D. Cinar (2001). Nationality Law and Naturalisation in Austria. In: Hansen, R. \& P. Weil (eds.), Towards a European Nationality. Citizenship, Immigration and Nationality Law in the EU. Basingstoke: Palgrave, 255-272.

Bauböck, R. \& B. Perching (2007). Evaluation and recommendations. In: Bauböck, R. et al. (eds.), Acquisition and Loss of Nationality. Policies and Trends in 15 European States. Volume 1: Comparative Analyses. Amsterdam: Amsterdam University Press, 431-478.

Bauböck, R., Perching, B. \& W. Sievers (2007) (eds.). Citizenship Policies in the New Europe. Amsterdam: Amsterdam University Press.

Becerra Ramirez, M. (2000). Nationality in Mexico. In: Aleinikoff, T. A. \& D. Klusmeyer (eds.), From migrants to citizens. Membership in a changing world. Washington: Carnegie Endowment for International Peace, 312-341.

Benhabib, S. (2004). The Rights of Others. Aliens, Residents and Citizens. Cambridge: Cambridge University Press.

Benhabib, S. (2005). Borders, Boundaries, and Citizenship. PS: Political Science and Politics 38(4): 673-678.

Benhabib, S. (2007). Twilight of Sovereignty or the Emergence of Cosmopolitan Norms? Rethinking Citizenship in Volatile Times. Citizenship Studies 11(1): 19-36.

Berg, E. \& W. van Meurs (2001). Legacies of the Past, Ethnic and Territorial Conflict Potentials. In Kempe, I. (ed.), Beyond EU Enlargement. Vol. 1 - The Agenda of Direct Neighbourhood for Eastern Europe. Gütersloh: Bertelsmann Foundation Publishers.

Bernitz, H. \& H. L. Bernitz (2006). Sweden. In: Bauböck, R. et al. (eds.), Acquisition and Loss of Nationality. Policies and Trends in 15 European States. Volume 2: Country Analyses. Amsterdam: Amsterdam University Press, 517-550.

Betts, K. (2002): Democracy and Dual Citizenship. People and Place 10(1): 57-70.

Bloemraad, I. (2004). Who claims dual citizenship? The limits of Postnationalism, the Possibilities of Transnationalism, and the Persistence of Traditional Citizenship. International Migration Review 38(2): 389-426.

Bloemraad, I. (2007). Much Ado about Nothing? The Contours of Dual Citizenship in the United States and Canada. In: Faist, T. \& P. Kivisto (eds.), Dual Citizenship in Global Perspective. From Unitary to Multiple Citizenship. Basingstoke: Palgrave Macmillan, 159-188.

Bohmann, J. (2007). Democracy across Borders. From Dêmos to Dêmoi. Cambridge, London: MIT Press.

Bosniak, L. (2001). Denationalizing Citizenship. In: Aleinikoff, T.A. \& D. Klusmeyer (eds.), Citizenship Today. Global Perspectives and Practices. Washington, D.C.: Carnegie Endowment for International Peace, 237 - 252.

Bosniak, L. (2003). Multiple nationality and the postnational transformation of citizenship. In: Martin, D. A. \& K. Hailbronner (eds.), Rights and Duties of Dual Nationals. Evolution and Prospects. The Hague, London, New York: Kluwer Law International, 27-48.

Brand, L. (2007). State, Citizenship, and Diaspora: the Cases of Jordan and Lebanon. The Center for Comparative Immigration Studies, University of California, San Diego,Working Paper 146, February 2007 <http://www.ccis-ucsd.org/PUBLICATIONS/wrkg146.pdf>

Brands-Kehre, I.\& I. Pice (2005). Political nation and citizenship. Audit of Democracy, SPPI, SAK, LU <http://www.politika.lv/index.php?id=3373>

Brodie, J. (2002). Citizenship and Solidarity: Reflections on the Canadian Way. Citizenship Studies 6 (4): 377-394.

Brubacker, R. (1992). Citizenship and Nationhood in France and Germany. London \& Cambridge, Mass: Harvard University Press. 
Brubacker, W. R. (1989) (ed.). Immigration and the Politics of Citizenship in Europe and North America. Lamham, New York, London: University Press of America.

Buchanan, A. (2004). Justice, Legitimacy, and Self-Determination. Moral Foundations for International Law. Oxford: Oxford University Press.

Bultmann, P.F. (2002). Dual Nationality and Naturalisation Policies in the German Laender. In: Hansen, R. \& P. Weil (eds.), Dual nationality, social rights and federal citizenship in the US and Europe: the reinvention of citizenship. Berghahn Books, 136-157.

Buttigeig, E. (2007). Malta's citizenship law: Evolution and current regime. In: Bauböck, R., Perching, B. \& W. Sievers (eds.), Citizenship Policies in the New Europe. Amsterdam: Amsterdam University Press, 245-262.

Carens, J. H. (2001). Reflections on American Citizenship and Immigration. $<$ http://www.cis.org/artciles/cantigny/carens.html>

Carens, J.H. (2002). Citizenship \& Civil Society: What Rights for Residents. In: Hansen, R. \& P. Weil (eds.), Dual nationality, social rights and federal citizenship in the US and Europe: the reinvention of citizenship. Berghahn Books, 100-120.

Castles, S. (2005). Hierachical Citizenship in a World of Unequal Nation-States. PS: Political Science and Politics 38(4): 689-692.

Castles, S. \& A. Davidson (2000). Citizenship \& Migration. Globalization and the Politics of Belonging. Basingstoke: Palgrave Macmillan.

Chopin, I. (2007). Administrative practices in the acqusition of nationality. In: Bauböck, R. et al. (eds.), Acquisition and Loss of Nationality. Policies and Trends in 15 European States. Volume 1: Comparative Analyses. Amsterdam: Amsterdam University Press, 221-268.

Christopoulos, D. (2004). Dual citizenship in the era of migration/repatriation to Greece. In: Tsapogas, M. and D. Christopoulos (eds.), The rights in Greece (1953-2003). Athens: Kastaniotis, 99-109. [in Greek]

Christopoulos, D. (2004). The immigrants in the Greek political community. In: Christopoulos, D. and M. Pavlou (eds.), Greece of immigration. Social participation, rights and quality of being citizen. Athens: Kritiki/KEMO, 338-366. [in Greek]

Christopoulos, D. (2004). The Greece of the "homogeneia": From mother-country, capitalistic metropolis. In: Minorities in Greece, Athens: Etaireia Spoudon Neoellinikou Politismou kai Genikis Paideias, 431-456. [in Greek]

Christopoulos D. and K. Tsitselikis (2004). Impasses of treatment regarding minorities and homogeneis in Greece. Jahrbücher für Geschichte und Kultur Südosteuropas, 5/2004: 81-93.

Christopoulos, D. (2006). Greece. In: Bauböck, R. et al. (eds.), Acquisition and Loss of Nationality. Policies and Trends in 15 European States. Volume 2: Country Analyses. Amsterdam: Amsterdam University Press, 253-288.

Cinar, D. (2007). Integration vor Einbürgerung: Staatsbürgerschaftsnovelle 2005. In: Fassmann (hg.), Österreichischer Migrations- und Integrationsbericht 2001-2006: Rechliche Rahmenbedingungen, demographische Entwicklungen, sozioökonomische Strukturen. Klagenfurt, Celovec: Drava Verlag.

Cohen, J.L. (1999). Changing Paradigms of Citizenship and the Exclusiveness of the Demos. International Sociology 14(3): 245-268.

Conant, L. (2001). Contested Boundaries. Citizens, States, and Supranational Belonging in the European Union. RSC EUI Working Papers No. 2001/27. San Domenico: EUI.

Conrad, C. \& J. Kocka (2001) (eds.), Staatsbürgerschaft in Europa. Historische Erfahrungen und aktuelle Debatten. Hamburg: edition Körber-Stiftung.

Correa, M. J. (2002). Seeking shelter: Immigrants and the Divergence of Social Rights and Citizenship in the United States. In: Hansen, R. \& Weil, P. (eds.), Dual nationality, social rights and federal citizenship in the US and Europe: the reinvention of citizenship. Berghahn Books, 233263.

Cronin, C. \& P. de Greiff (2002). Editors' Introduction. In: Habermas, J., The Inclusion of the Other. Studies in Political Theory. Cambridge: Polity.

Crwoley, J. (1998). The National Dimension of Citizenship in T.H. Marshall. Citizenship Studies 2(2): 165-178.

Dahlin, E.C. \& A. Hironaka (2008): Citizenship Beyond Borders: A cross-national study of dual citizenship. Sociological Inquiry 78(1): 54-73. 
Davis, U. (1997). Citizenship and the State: A Comparative Study of Citizenship Legislation in Israel, Jordan, Palestine, Syria and Lebanon. Ithica Press.

Davy, U. (2001) (Hg.), Die Integration von Einwanderern. Rechtliche Regelungen im europäischen Vergleich. Frankfurt, New York: Campus.

Davy, U. \& D. Cinar (2001). Österreich. In: Davy, U. (Hg.), Die Integration von Einwanderern. Rechtliche Regelungen im europäischen Vergleich. Frankfurt, New York: Campus, 567-708.

Dilek, C. \& H. Waldrauch (2006). Austria. In: Bauböck, R. et al. (eds.), Acquisition and Loss of Nationality. Policies and Trends in 15 European States. Volume 2: Country Analyses. Amsterdam: Amsterdam University Press, 19-62.

Dummett, A. (2006). United Kingdom. In: Bauböck, R. et al. (eds.), Acquisition and Loss of Nationality. Policies and Trends in 15 European States. Volume 2: Country Analyses. Amsterdam: Amsterdam University Press, 551-586.

Dusan, D. (2003). Immigration and the Czech Republic (with a Special Focus on the Foreign Labor Force). International Migration Review 37(1).

Eksi, N. (2003). Consequences of Dual Nationality with regard to Residence, Employment, Ownership in Immovable Property, Military Service and Holding Political Office in Turkish Law. In: Martin, D. A. \& K. Hailbronner (eds.), Rights and Duties of Dual Nationals. Evolution and Prospects. The Hague, London, New York: Kluwer Law International, 375-382.

Eksi, N. (2003). Political Rights of Dual Nationals in Turkish Law. In: Martin, D. A. \& Hailbronner, K. (eds.), Rights and Duties of Dual Nationals. Evolution and Prospects. The Hague, London, New York: Kluwer Law International, 153-156.

El Nashef, A. \& N. Thalg-Massoud (1999). The Lebanese Nationality between the Law and Interpretation. Lebanon: El Halaby Legal Publications. [in Arabic]

Entzinger, H. \& Biezeveld, R. (2003). Benchmarking in Immigrant Integration. Erasmus Universiteit Rotterdam.

Ersbøll, E. (2001). Nationality Law in Denmark, Finland and Sweden. In: Hansen, R. \& P. Weil (eds.), Towards a European Nationality. Citizenship, Immigration and Nationality Law in the EU. Basingstoke: Palgrave, 230-254.

Ersbøll, E. (2003). Statsborgerskab - medborgarskap - eurpÃ liske konvergens - nordisk divergens? Nordic Journal of human rights 21 (2).

Ersbøll, E. (2006). Denmark. In: Bauböck, R. et al. (eds.), Acquisition and Loss of Nationality. Policies and Trends in 15 European States. Volume 2: Country Analyses. Amsterdam: Amsterdam University Press, 105-148.

Ersbøll, E. (2007). Hvad er en dansker? In: Ersbøll, E., Koch, I. E., Lassen, E.M. \& S. Lagoutte (eds.), Denne verden fortjener at blive forandret: hyldest til Isi Foighel. Kobenhavn: Jurist- og Okonomforbundets Forlag.

Ersbøll, E. (2008). Dansk Indisret i International og Historisk Belysning (English summary). Kobenhavn: Jurist- og Okonomforbundets Forlag. [forthcoming]

Escobar, C. (2004). Dual Citizenship and Political Participation: Migrants in the Interplay of United States and Colombian Politics. Latino Studies 2(1): 45-69.

Escobar, C. (2007). Extraterritorial Political Rights and Dual Citizenship in Latin America. Latin American Research Review 42 (3): 43-75.

Ette, A. \& T. Faist (2007). The Europeanization of National Policies and Politics of Immigration. Between Autonomy and the European Union. Basingstoke: Palgrave Macmillan.

Ette, A. \& T. Faist (2007). The Europeanization of National Policies and Politics of Immigration: Research, Questions \& Concepts. In: Ette, A. \& T. Faist (eds.), The Europeanization of National Policies and Politics of Immigration. Between Autonomy and the European Union. Basingstoke: Palgrave Macmillan, 3-31.

Everson, M. (2003). 'Subjects' or Çitizens of Erewhon'? Law and Non-Law in the development of a 'British Citizenship'. Citizenship Studies 7(1): 57-83.

Fagerlund, J. (2006). Finland. In: Bauböck, R. et al. (eds.), Acquisition and Loss of Nationality. Policies and Trends in 15 European States. Volume 2: Country Analyses. Amsterdam: Amsterdam University Press, 149-186.

Faist, T. (2007) (ed.): Dual Citizenship in Europe. From Nationhood to Social Integration. Aldershot: Ashgate.

Faist, T. (2007). Dual Citizenship: Change, Prospects, and Limits. In: Faist, T. (ed.), Dual Citizenship in Europe. From Nationhood to Social Integration. Aldershot: Ashgate, 171-200. 
Faist, T. (2007). Introduction: The Shifting Boundaries of the Political. In: Faist, T. \& P. Kivisto, Dual Citizenship in Global Perspective. From Unitary to Multiple Citizenship. Basingstoke: Palgrave Macmillan, 1-26.

Faist, T. (2007). The Fixed and Porous Boundaries of Dual Citizenship. In: Faist, T. (ed.), Dual Citizenship in Europe. From Nationhood to Social Integration. Aldershot: Ashgate, 1-44.

Faist, T., Gerdes, J. \& B. Rieple (2004). Dual Citizenship as a Path-Dependent Process. International Migration Review 38(3): 913-944.

Faist, T. \& P. Kivisto (2007). Dual Citizenship in Global Perspective. From Unitary to Multiple Citizenship. Basingstoke: Palgrave Macmillan.

Falk, R. (2000). The Decline of Citizenship in an Era of Globalization. Citizenship Studies 4 (1): 517.

Farha, M. (2008). Demography \& Democracy in Lebanon. MidEast Monitor 4 (1): $<$ http://www.mideastmonitor.org/issues/0801/0801_2.htm>

Faulks, K. (2000). Citizenship. London \& New York: Routledge.

Favell, A. (2001). Philosophies of Integration. Immigration and the Idea of Citizenship in France and Britain. Migration, Minorities, and Citizenship. Basingstoke, New York: Palgrave Macmillan.

Foblets, M.-Cl. \& S. Loones (2006). Belgium. In: Bauböck, R. et al. (eds.), Acquisition and Loss of Nationality. Policies and Trends in 15 European States. Volume 2: Country Analyses. Amsterdam: Amsterdam University Press, 63-104.

Fonte, J. (2006). Dual Allegiance is Inconsistent with American Democracy. Foreign Policy in Focus (www. fpif.org)

Fonte, J. (2006). To "Possess the National Consciousness of an American". $<$ http://www.cis.org/articles/cantigny/fonte.html>

Fuentes, F. J. M. (2001). Migration and Spanish Nationality Law. In: Hansen, R. \& P. Weil (eds.), Towards a European Nationality. Citizenship, Immigration and Nationality Law in the EU. Basingstoke: Palgrave, 118-142.

Fukuyama, F. (2006). Identity, Immigration, and Liberal Democracy. Journal of Democracy 17(2): 5-20.

Galloway, D. (2000). The Dilemmas of Canadian Citizenship Law. In: Aleinikoff, T. A. \& D. Klusmeyer (eds.), From migrants to citizens. Membership in a changing world. Washington: Carnegie Endowment for International Peace, 82-118.

Gamberale, C. (1997). European Citizenship and Political Identity. Space \& Polity 1(1): 37-59.

Gerdes, J. \& T. Faist (2007). Varying views on Democracy, Rights and Duties, and Membership: The politics of Dual Citizenship in European Immigration states. In: Faist, T. \& P. Kivisto (eds.), Dual Citizenship in Global Perspective. From Unitary to Multiple Citizenship. Basingstoke: Palgrave Macmillan, 135-158.

Gerdes, J., Faist, T. \& B. Rieple (2007). 'We are all '"Republicans" now': The Politics of Dual Citizenship in Germany. In: Faist, T. (ed.), Dual Citizenship in Europe. From Nationhood to Social Integration. Aldershot: Ashgate, 45-76.

Gerhard, U. (2001). Bürgerrechte \& Geschlecht. Herausforderung für ein soziales Europa. In: Conrad, C. \& J. Kocka (hrsg.), Staatsbürgerschaft in Europa. Historische Erfahrungen und aktuelle Debatten. Hamburg: edition Körber-Stiftung, 63-91.

Ginsburgs, G. (2000). Migration and Admittance to Citizenship in Russia. In: Aleinikoff, T. A. \& D. Klusmeyer (eds), From migrants to citizens. Membership in a changing world. Washington: Carnegie Endowment for International Peace, 178-220.

Giugni, M. \& F. Passy (2004). Migrant mobilization between political institutions and citizenship regimes: A comparison of France and Switzerland. European Jounral of Political Research 43: 51-82.

Glytsos, Nicholas P. (2005). Stepping from Illegality to Legality and Advancing towards Integration: The Case of Immigrants in Greece. International Migration Review 39(4).

Górny, A. (2007). Same letter, new spirit: Nationality regulations and their implementation in Poland. In: Bauböck, R., Perching, B. \& W. Sievers (eds.), Citizenship Policies in the New Europe. Amsterdam: Amsterdam University Press, 113-134.

Górny, A., Grzymala-Kazłowska, A., Koryś, P. \& A. Weinar (2007). Selective Tolerance? Regulation, Practice and Discussions Regarding Dual Citizenship in Poland. In: Faist, T. (ed.): Dual Citizenship in Europe. From Nationhood to Social Integration. Aldershot: Ashgate, 147-170. 
Gosewinkel, D. (2001). Staatsangehörigkeit in Deutschland und Frankreich im 19. und 20. Jahrhundert. In: Conrad, C. \& J. Kocka (hrsg.). Staatsbürgerschaft in Europa. Historische Erfahrungen und aktuelle Debatten. Hamburg: edition Körber-Stiftung, 48-62.

Green, S. (2001). Citizenship Policy in Germany: The Case of Ethnicity over Residence. In: Hansen, R. \& P. Weil (eds.). Towards a European Nationality. Citizenship, Immigration and Nationality Law in the EU. Basingstoke: Palgrave, 24-51.

Green, S. (2005). Between Ideology and Pragmatism: The Politics of Dual Nationality in Germany. International Migration Review 39(4): 921-952.

Groenendijk, K. (1993). Nationality, Minority and Statelessness: The Case of the Baltic States. Helsinki Monitor 4 (3): 13-25.

Groenendijk, K. (2007). The legal integration of potential citizens: Denizens in the EU in the final years before the implementation of the 2003 Directive on long-term resident third country nationals. In: Bauböck, R. et al. (eds.), Acquisition and Loss of Nationality. Policies and Trends in 15 European States. Volume 1: Comparative Analyses. Amsterdam: Amsterdam University Press, 385-410.

Groenendijk, K. (2007). The status of quasi-citizenship in EU member states: Why some states have 'almost citizens'. In: Bauböck, R. et al. (eds.), Acquisition and Loss of Nationality. Policies and Trends in 15 European States. Volume 1: Comparative Analyses. Amsterdam: Amsterdam University Press, 411-430.

Groendijk, K., Hart, B. de \& R. van Oers (2006). The Netherlands. In: Bauböck, R. et al. (eds.), Acquisition and Loss of Nationality. Policies and Trends in 15 European States. Volume 2: Country Analyses. Amsterdam: Amsterdam University Press, 391-434.

Groendijk, K. \& E. Heijs (2001). Immigration, Immigrants and Nationality Law in the Netherlands, 1945-98. In: Hansen, R. \& P. Weil (eds.), Towards a European Nationality. Citizenship, Immigration and Nationality Law in the EU. Basingstoke: Palgrave, 143-172.

Groot, G.-R. de (2003). Loss of Nationality: A critical inventory. In: D. A. Martin \& K. Hailbronner (eds.), Rights and Duties of Dual Nationals. Evolution and Prospects. The Hague, London, New York: Kluwer Law International, 201-302.

Gunsteren, H.R. van (1998). A Theory of citizenship. Boulder \& Cumnor Hill: Westview Press.

Gustafson, P. (2002). Globalisation, multiculturalism and individualism: The Swedish debate on dual citizenship. Journal of Ethnic and Migration Studies 28(3):463-481.

Gustafson, P. (2005). International Migration and National Belonging in the Swedish Debate on Dual Citizenship. Acta Sociologica 48(1): 5-19.

Haddad, S. (2000). Palestinians in Lebanon: Towards Integration or Conflict? Palestinian Refugees Research Net. <http://www.arts.mcgill.ca/MEPP/PRRN/papers/haddad.html>

Hagedorn, H. (2003). Administrative Systems and Dual Nationality: The Information Gap. In: Martin, D.A. \& K. Hailbronner (eds.), Rights and Duties of Dual Nationals. Evolution and Prospects. The Hague, London, New York: Kluwer Law International, 183-200.

Hailbronner, K. (2003). Rights and Duties of Dual Nationals: Changing Concepts and Attitudes. In: Martin, D.A. \& K. Hailbronner (eds.), Rights and Duties of Dual Nationals. Evolution and Prospects. The Hague, London, New York: Kluwer Law International, 19-26.

Hailbronner, K. (2007). Nationality in public international law and European law. In: Bauböck, R. et al. (eds.), Acquisition and Loss of Nationality. Policies and Trends in 15 European States. Volume 1: Comparative Analyses. Amsterdam: Amsterdam University Press, 35-104.

Halfmann, J. (1997). Two discourses of citizenship in Germany. The difference between public debate and administrative practice. Citizenship Studies 1(3): 305-322.

Hammar, T. (1989). State, Nation, and Dual Citizenship. In: Brubacker, W. R. (ed.), Immigration and the Politics of Citizenship in Europe and North America. Lamham, New York, London: University Press of America, 81-96.

Hampshire, J. (2005). Citizenship and Belonging. Immigration and the Politics of Demographic Governance in Postwar Britain. Houndsmill, Basinstoke, Hampshire, New York: Palgrave Macmillan.

Handoll, J. (2006). Ireland. In: Bauböck, R. et al. (eds.), Acquisition and Loss of Nationality. Policies and Trends in 15 European States. Volume 2: Country Analyses. Amsterdam: Amsterdam University Press, 289-328.

Hansen, R. \& P. Weil (2001) (eds.). Towards a European Nationality. Citizenship, Immigration and Nationality Law in the EU. Basingstoke: Palgrave. 
Hansen, R. \& P. Weil (2001). Introduction. Citizenship, Immigration and Nationality. Towards a Convergence in Europe? In: Hansen, R. \& P. Weil (eds.), Towards a European Nationality. Citizenship, Immigration and Nationality Law in the EU. Basingstoke: Palgrave, 1-23.

Hansen, R. \& Weil, P. (2002) (eds.). Dual nationality, social rights and federal citizenship in the US and Europe: the reinvention of citizenship. Berghahn Books.

Hansen, R. \& P. Weil (2002). Introduction - Dual Citizenship in a changed world: Immigration, Gender and Social Rights. In: ibid. (eds.), Dual nationality, social rights and federal citizenship in the US and Europe: the reinvention of citizenship. Berghahn Books, 1-18.

Hansen, R. \& J. Köhler (2005). Issue Definition, political discourse and the politics of nationality reform in France and Germany. European Journal of Political Research 44: 623-643.

Harinen, P., Pitkänen, P., Sagne, S. \& J. Ronkainen (2007). Multiple citizenship as a challenge for Finnish citizenship policy today. In: Kalekin-Fishman, D. \& P. Pitkänen (eds.), Multiple Citizenship as a Challenge to European Nation-States. Rotterdam: Sense Publishers, 121-144.

Hart, B. de (2007). The End of Multiculturalism: The End of Dual Citizenship? Political and Public Debates on Dual citizenship in The Netherlands (1980-2004). In: Faist, T. (ed.), Dual Citizenship in Europe. From Nationhood to Social Integration. Aldershot: Ashgate, 77-102.

Hart, B. de \& R. van Oers (2007). European trends in nationality law. In: R. Bauböck et al. (eds.), Acquisition and Loss of Nationality. Policies and Trends in 15 European States. Volume 1: Comparative Analyses. Amsterdam: Amsterdam University Press, 317-358.

Heater, D. (2004). Citizenship. The civis ideal in world history, politics and education. Manchester \& New York: Manchester University Press.

Heilbronner, K. (2002). Germany's Citizenship Law under Immigration Pressure. In: Hansen, R. \& Weil, P. (eds.), Dual nationality, social rights and federal citizenship in the US and Europe: the reinvention of citizenship. Berghahn Books, 121-135.

Heilbronner, K. (2006). Germany. In: Bauböck, R. et al. (eds.), Acquisition and Loss of Nationality. Policies and Trends in 15 European States. Volume 2: Country Analyses. Amsterdam: Amsterdam University Press, 213-252.

Heisler, M.O. (2005). Introduction - Changing Citizenship Theory and Practice: Comparative Perspectives in a Democratic Framework. PS: Political Scinece and Politics 38(4): 667-672.

Heitmeyer, W. \& P. Imbusch (2005). Integration und Desintegration in modernen Gesellschaften. In: ibid., Integrationspotenziale einer modernen Gesellschaft. Wiesbaden: Verlag für Sozialwissenschaften, 13-75.

Helbing, M. \& H. Kriesi (2004). Staatsbürgerschaftsverständnis und politische Mobilisierung: Einbürgerungen in Schweizer Gemeinden. Swiss Political Science Review 10(4): 33-58.

Helbing, M. (2007). Citizenship, Right-Wing Populism and the Direct Democratic Dilemma. (preparation for a publication in a volume)

Helman, Sara (1999). Negotiating Obligations, Creating Rights: Conscientious Objection and the Redefinition of Citizenship in Israel. Citizenship Studies 3(1): 45-70.

Hofhansel, C. (2008). Citizenship in Austria, Germany, and Switzerland: Courts, Legislatures, and Administrators. International Migration Review 42(1).

Hofmann, G. (2004). Stellvertreter am Katzentisch. Die Zeit Nr. 24 (03 June 2004).

Howard, M.M. (2005). Variation in Dual Citizenship Policies in the Countries of the EU. International Migration Review 39(3): 697-720.

Howard, M.M. (2006). Comparative Citizenship: An Agenda for cross-national research. Perspectives on Politics 4(3): 443-455.

Howard, M.M. (2008). The causes and consequences of Germany's new citizenship law. German Politics 17: 41-62.

Hunger, U. \& H. Kolb (2003). Die deutsche 'Green Card'. Migration von Hochqualifizierten in theoretischer und empirischer Perspektive. IMIS-Beiträge. Heft 22/2003. Osnabrück.

Isin, E.F. \& B.S. Turner (2007). Investigating Citizenship: An Agenda for Citizenship Studies. Citizenship Studies 11(1): 5-17.

Itzigsohn, J. (2007). Migration and Transnational Citizenship in Latin America: The Cases of Mexico and the Domincan Republic. In: Faist, T. \& P. Kivisto (eds.), Dual Citizenship in Global Perspective. From Unitary to Multiple Citizenship. Basingstoke: Palgrave Macmillan, 113-134.

Jacobson, D. (1996). Novus Ordo Seclorum. In: Jacobson, D. (ed.), Rights across Borders. Baltmimore \& London: The John Hopkins University Press, 1-17. 
Järve, P. (2007). Estonian citizenship: Between ethnic preferences and democratic obligations. In: Bauböck, R., Perching, B. \& W. Sievers (eds.), Citizenship Policies in the New Europe. Amsterdam: Amsterdam University Press, 43-62.

Jaulin, T. (2006). Lebanese Politics of Nationality and Emigration. EUI Working Papers RSCAS No. 2006/29.

Johnston, P. (2001). The Emergence of Transnational Citizenship among Mexican Immigrants in California. In: Aleinikoff, T.A. \& D. Klusmeyer (eds.), Citizenship Today. Global Perspectives and Practices. Washington, D.C.: Carnegie Endowment for International Peace, 253-277.

Jones-Correa, M. (2001). Under Two Flags: dual Nationality in Latin America and Its Consequences for Naturalization in the United States. International Migration Review 35(4): 9971029.

Joppke, C. (2007). Beyond National Models: Civic Integration Policies for Immigrants in Western Europe. West European Politics 30(1): 1-22.

Joppke, C. (2007). Transformation of Citizenship: Status, Rights, Identity. Citizenship Studies 11(1): 37-48.

Kadioglu, A. (2007). Denationalization of Citizenship? The Turkish Experience. Citizenship Studies 11(3): 283-299.

Kadirbeyoglu, Z. (2007). Changing conceptions of citizenship in Turkey. In: Bauböck, R., Perching, B. \& W. Sievers (eds.), Citizenship Policies in the New Europe. Amsterdam: Amsterdam University Press, 293-312.

Kadirbeyoglu, Z. (2007). National Transnationalism: Dual Citizenship in Turkey. In: Faist, T. (ed.), Dual Citizenship in Europe. From Nationhood to Social Integration. Aldershot: Ashgate, 127146.

Kalekin-Fishman, D. \& P. Pitkänen (2007) (eds.), Multiple Citizenship as a Challenge to European Nation-States. Rotterdam: Sense Publishers.

Kalekin-Fishman, D. (2007). Multiple Citizenship: Mark of dominance and privilege: the situation in Israel. In: Kalekin-Fishman, D. \& P. Pitkänen (eds.), Multiple Citizenship as a Challenge to European Nation-States. Rotterdam: Sense Publishers, 239-267.

Kalekin-Fishman, D., Tsitselikis, K. \& P. Pitkänen (2007). Theorizing multiple citizenship. In: Kalekin-Fishman, D. \& P. Pitkänen (eds.), Multiple Citizenship as a Challenge to European Nation-States. Rotterdam: Sense Publishers, 1-38.

Kalev, L. \& R. Ruutso (2007). The shadow of the past and the promise of the EU: National and Multiple citizenship - the Estonian case. In: Kalekin-Fishman, D. \& P. Pitkänen (eds.), Multiple Citizenship as a Challenge to European Nation-States. Rotterdam: Sense Publishers, 213-238.

Kalvaitis, R. (1998). Citizenship and national identity in the Baltic States. Boston University International Law Journal 16: 231-271.

Karatani, R. (2003). Defining British Citizenship: Empire, Commonwealth, and Modern Britain. Cass Series - British Politics and Society, 1467-1441. London, Portland: OR Taylor \& Francis Routledge.

Kashiwazaki, C. (2000). Citizenship in Japan. Legal Practice and Contemporary Development. In: Aleinikoff, T. A. \& D. Klusmeyer (eds.), From migrants to citizens. Membership in a changing world. Washington: Carnegie Endowment for International Peace, 434-474.

Kastoryano, R. (2002). Türken mit Deutschem Pass. Sociological and Political Perspectives on dual Nationality in Germany. In: Hansen, R. \& P. Weil (eds.), Dual nationality, social rights and federal citizenship in the US and Europe: the reinvention of citizenship. Berghahn Books, 158178.

Kastoryano, R. (2005). Citizenship, Nationhood, and Non-Territoriality: Transnational Participation in Europe. PS: Political Science and Politics 38(4): 693-697.

Kessler, A.E. \& G.P. Freeman (2005). Public Opinion in the EU on Immigration from Outside the Community. Journal of Common Market Studies 43(4): 825-850.

Keyman, E.F. \& A. Icduygu (2003). Globalization, Civil Society and Citizenship in Turkey: Actors, Boundaries and Discourses. Citizenship Studies 7 (2): 219-234.

Kiernan, A.K. (1997). Citizenship - The Real Democratic deficit of the European Union? Citizenship Studies 1(3): 323-334.

Kivisto, P. \& T. Faist (2007): Citizenship. Discourse, Theory, and Transnational Prospects. Malden, Oxford, Carlton: Blackwell. 
Kivisto, P. (2007). Conclusion: The Boundaries of Citizenship in a Transitional Age. In: Faist, T. \& P. Kivisto (eds.), Dual Citizenship in Global Perspective. From Unitary to Multiple Citizenship. Basingstoke: Palgrave Macmillan, 272-287.

Klaaren, J. (2000). Post-Apartheid Citizenship in South-Africa. In: Aleinikoff, T. A. \& D. Klusmeyer (eds.), From migrants to citizens. Membership in a changing world. Washington: Carnegie Endowment for International Peace, 221-252.

Kleger, H. (ed.) (1997). Transnationale Staatsbürgerschaft. Frankfurt/Main, New York: Campus Verlag.

Klusmeyer, D. (2001). Introdtion. In: Aleinikoff, T.A. \& D. Klusmeyer (eds.). Citizenship Today. Global Perspectives and Practices. Washington, D.C.: Carnegie Endowment for International Peace, 1-16.

Koenig-Archibugi, M. (2003). National and European Citizenship: The Italian Case in Historical Perspective. Citizenship Studies 7(1): 85-109.

Koopmans, R. \& P. Statham (2000). Challenging immigration and ethnic relations politics: comparative European perspectives. Oxford: Oxford University Press.

Koopmans, R. \& P. Statham (2000). Migration and Ethnic Relations as a field of Political Contention: An Opportunity Structure Approach In: ibid. (eds.), Challenging immigration and ethnic relations politics: comparative European perspectives. Oxford: Oxford University Press, 13-56.

Koopmans, R. (2002). Zachte heelmeesters. Een vergelijking van de resultaten van het Nederlandse en Duitse integratiebeleid en wat de WRR daaruit niet concludeert. Migrantenstudies 18(2): 87-92.

Koopmans, R. et al. (eds.) (2005). Contested Citizenship. Immigration and Cultural Diversity in Europe. Minneapolis, London: University of Minnesota Press.

Koopmans, R. (2007). Cultuur maakt wel verschil, beste WRR. NRC Handelsblatt. 26 September 2007.

Koopmans, R., Statham, P., Giugni, M. \& F. Passy (2005). Contested Citizenship. Immigration and Cultural Diversity in Europe. Minneapolis: University of Minnesota Press.

Koslowski, R. (2003). Challenges of International Cooperation in a World of Increasing Dual Nationality. In: Martin, D.A. \& K. Hailbronner (eds.), Rights and Duties of Dual Nationals. Evolution and Prospects. The Hague, London, New York: Kluwer Law International, 157-182.

Kovács, M.M. (2006). The Politics of Dual Citizenship in Hungary. Citizenship Studies 10(4): 431451.

Kovács, M.M. (2007). The Politics of Dual Citizenship in Hungary. In: Faist, T. \& P. Kivisto (eds.), Dual Citizenship in Global Perspective. From Unitary to Multiple Citizenship. Basingstoke: Palgrave Macmillan, 92-112.

Kovács, M.M. \& J. Tóth (2007). Kin-state responsibility and ethnic citizenship: The Hungarian case. In: Bauböck, R., Perching, B. \& W. Sievers (eds.), Citizenship Policies in the New Europe. Amsterdam: Amsterdam University Press, 135-159.

Kreuzer, C. (2003). Double and Multiple Nationality in Germany after the Citizenship Reform Act of 1999. In: Martin, D. A. \& K. Hailbronner (eds.). Rights and Duties of Dual Nationals. Evolution and Prospects. The Hague, London, New York: Kluwer Law International, 347-360.

Kruma, K. (2007). Checks and balances in Latvian nationality policies: National agendas and international frameworks. In: Bauböck, R., Perching, B. \& W. Sievers (eds.), Citizenship Policies in the New Europe. Amsterdam: Amsterdam University Press, 63-88.

Kruma, K. (2007). Lithuanian nationality: Trump card to independence and its current challenges. In: Bauböck, R., Perching, B. \& W. Sievers (eds.), Citizenship Policies in the New Europe. Amsterdam: Amsterdam University Press, 89-109.

Kusá, D. (2007). The Slovak question and the Slovak answer: Citizenship during the quest for national self-determination and after. In: Bauböck, R., Perching, B. \& W. Sievers (eds.), Citizenship Policies in the New Europe. Amsterdam: Amsterdam University Press, 185-212.

Kveinen, E. (2002). Citizenship in a Post-Westphalian Community: Beyond External Exclusion? Citizenship Studies 6(1): 21-35.

Le Sout, D. \& A. Kadri (2007). Dual Nationality and nationality policy in France: Past and present. In: Kalekin-Fishman, D. \& P. Pitkänen (eds.), Multiple Citizenship as a Challenge to European Nation-States. Rotterdam: Sense Publishers, 59-80.

Lechner, F.J. (1998). Parsons on Citizenship. Citizenship Studies 2(2): 179-196. 
Lee, Chulwoo (2003). Us and Them in Korean Law: The Creation, Accomodation and Exclusion of Outsiders in South Korea. In: Rosett, A. (eds.), East-Asian Law - Universal Norms and Local cultures. London: Routledge Curzon.

Lee, Chulwoo (2008). The Deterritorialization and Reterritorialization of Sovereignty: The Logic of Dual Nationality. Korean Journal of Sociology 42(1): 27-61. [in Korean]

Lefebvre, E. L. (2003). Belgian Citizenship: Managing Linguistic, Regional and Economic Demands. Citizenship Studies 7(1): 111-134.

Lefebvre, E.L. (2003). Republicanism and Universalism: Factors of Inclusion or Exclusion in the French Concept of Citizenship. Citizenship Studies 7 (1): 15-36.

Leggewie, C. (2003). Florierende Nachbarschaft. Der wiedergefundene Stadtbürger - ein Wiener Kongress. Frankfurter Rundschau, 23. September 2003.

Liebich, A. (2007). Introduction: Altneuländer or the vicissitudes of citizenship in the new EU states. In: Bauböck, R., Perching, B. \& W. Sievers (eds.), Citizenship Policies in the New Europe. Amsterdam: Amsterdam University Press, 17-42.

Liénard-Ligny, M. (2001). Nationality Law in Belgium and Luxembourg. In: Hansen, R. \& P. Weil (eds.), Towards a European Nationality. Citizenship, Immigration and Nationality Law in the EU. Basingstoke: Palgrave, 193-213.

Linklater, A. (1998). Cosmopolitan Citizenship. Citizenship Studies 2(1): 23-42.

Mackert, J. (1999). Kampf um Zugehörigkeit. Nationale Staatsbürgerschaft als Modus sozialer Schließung. Opladen/Wiesbaden: Westdeutscher Verlag.

Macklin, A. (2007). The Securitisation of Dual Citizenship. In: Faist, T. \& P. Kivisto (eds.), Dual Citizenship in Global Perspective. From Unitary to Multiple Citizenship. Basingstoke: Palgrave Macmillan, 42-68.

Maktabi, R. (1999). The Lebanese Census of 1932 Revisited. Who Are the Lebanese? British Journal of Middle Eastern Studies 26(2)/<http://web.macam.ac.il/ arnon/IntME/extra/LEBANESE\%20CENSUS\%201932.htm>

Marshall, T.H. (1950). Citizenship and Social Class and other essays. Cambridge: Cambridge University Press.

Martin, D. (2002). New Rules for Dual Nationality. In: Hansen, R. \& P. Weil (eds.), Dual nationality, social rights and federal citizenship in the US and Europe: the reinvention of citizenship. Berghahn Books, 34-60.

Martin, D. A. (2003). Introduction: The Trend toward Dual Nationality. In: Martin, D.A. \& K. Hailbronner (eds.), Rights and Duties of Dual Nationals. Evolution and Prospects. The Hague, London, New York: Kluwer Law International, 3-18.

Martin, D. A. \& K. Hailbronner (2003) (eds.). Rights and Duties of Dual Nationals. Evolution and Prospects. The Hague, London, New York: Kluwer Law International.

Martin, P., Abella, M. \& E. Midgley (2004). Best Practices to Manage Migration: The Philippines. International Migration Review 2004 38(4): 15-44.

Martin, S. (2002). The Attack on Social rights: U.S. Citizenship Devalued. In: Hansen, R. \& P. Weil (eds.), Dual nationality, social rights and federal citizenship in the US and Europe: the reinvention of citizenship. Berghahn Books, 215-232.

Mauerhofer K. (2004). Mehrfache Staatsangehörigkeit aus Sicht des schweizerischen Rechts. Basel: Helbling \& Lichtenhahn.

Mazzaroli, F. (2005). Determinants of Naturalization: The Role of Dual Citizenship Laws. CCIS Working Paper 117.

Medved, F. (2007). From civic to ethnic community? The evolution of Slovenian citizenship. In: Bauböck, R., Perching, B. \& W. Sievers (eds.), Citizenship Policies in the New Europe. Amsterdam: Amsterdam University Press, 213-241.

Messari, Nizar (2001). National security, the political space and citizenship: the case of Morocco. The Journal of North African studies 6(4): 47-63.

Moyse, F., Brasseur, P. \& D. Scuto (2006). Luxembourg. In: Bauböck, R. et al. (eds), Acquisition and Loss of Nationality. Policies and Trends in 15 European States. Volume 2: Country Analyses. Amsterdam: Amsterdam University Press, 367-390.

Oboler, Suzanne (2006) (ed.). Latinos and Belonging. Basingstoke, New York: Palgrave Macmillan. 
Odmalm, P. (2005). Migration Policies and Political Participation: Inclusion or Intrusion in Western Europe? Migration, Minorities, and Citizenship. Basingstoke, New York: Palgrave Macmillan.

Ong, A. (2005). (Re-)Articulation of Citizenship. PS: Political Science and Politics 38(4): 697-700.

Papp, T. (1999). Who is In, Who is Out? Citizenship, Nationhood, Democracy, and European Integration in the Czech Republic and Slovakia. EUI Working Paper RSC No. 99/13. EUI: San Domenico.

Pastore, F. (2001). Nationality Law and International Migration. The Italian Case. In: Hansen, R. \& P. Weil (eds.). Towards a European Nationality. Citizenship, Immigration and Nationality Law in the EU. Basingstoke: Palgrave, 95-117.

Peled, Y. (2005). Restoring Ethnic Democracy: The Or Commission and Palestinian Citizenship in Israel Citizenship Studies 9(1): 89-105.

Perczynski, P. \& Vink, M. (2002). Citizenship \& Democracy: A Journey to Europe's Past. Citizenship Studies 6(2): 183-199.

Pertes, A. (1997). Immigration Theory for a New Century: Some Problems and Opportunities International Migration Review 31(4): 799-825.

Peruzzotti, E. (2002). Towards a New Politics: Citizenship and Rights in Contemporary Argentina. Citizenship Studies 6(1): 77-93.

Pradelle, G. de la (2002). Dual Nationality and the French Citizenship Tradition. In: Hansen, R. \& P. Weil (eds.), Dual nationality, social rights and federal citizenship in the US and Europe: the reinvention of citizenship. Berghahn Books, 191-214.

Preston, V., Siemiatycki, M. \& A. Kobayashi (2007). Dual Citizenship among Hong Kong Canadians: Convenience or Commitment? In: Faist, T. \& P. Kivisto (eds.), Dual Citizenship in Global Perspective. From Unitary to Multiple Citizenship. Basingstoke: Palgrave Macmillan, 203-226.

Preuss, U.K. (2003). Citizenship and the German Nation. Citizenship Studies 7(1): 37-56.

Preuss, U.K., Everson, M., Koenig-Archibugi, M. \& E. Lefebvre (2003). Traditions of Citizenship in the European Union. Citizenship Studies 7(1): 3-14.

Ramos, M. (2001). Migratory Movements and Nationality Law in Portugal. In: Hansen, R. \& P. Weil (eds.), Towards a European Nationality. Citizenship, Immigration and Nationality Law in the EU. Basingstoke: Palgrave, 214-229.

Ramos, M. \& M. Gomes (2005). Dual/Multiple Citizenship in Portugal. In: Schröter, Y., Mengelkamp, C. \& R. Jäger (eds.), Doppelte Staatsbürgerschaft, Landau: Verlag Empirische Padagogik, 309-335.

Ramos, M. \& M. Gomes (2007). Dual Citizenship, governance and education: The situation in Portugal. In: Kalekin-Fishman, D. \& P. Pitkänen (eds.), Multiple Citizenship as a Challenge to European Nation-States. Rotterdam: Sense Publishers, 171-212.

Randall, H. (2001). From Subjects to Citizens. Immigration and Nationality Law in the United Kingdom. In: Hansen, R. \& P. Weil (eds.), Towards a European Nationality. Citizenship, Immigration and Nationality Law in the EU. Basingstoke: Palgrave, 69-94.

Randall, H. (2002). The dog that didn't bark: dual Nationality in the United Kingdom. In: Hansen, R. \& P. Weil (eds.), Dual nationality, social rights and federal citizenship in the US and Europe: the reinvention of citizenship. Berghahn Books, 179-190.

Renshon, S.A. (2004). Dual Citizenship and American Democracy: Patriotism, National Attachment, and National Identity. Social Philosophy \& Policy

Renshon, S.A. (2005). The 50\% American. Immigration and National Identity in an Age of Terror. Washington: Georgetown University Press.

Roggeband, C. \& R. Vliegenthart (2007). Divergent Framing: The Public Debate on Migration in the Dutch Parliament and Media, 1995-2004. West European Politics 30(3): 524-548.

Rozakis, C. L. (2001). Nationality Law in Greece. In: Hansen, R. \& P. Weil (eds.), Towards a European Nationality. Citizenship, Immigration and Nationality Law in the EU. Basingstoke: Palgrave, 173-192.

Rubio-Marin, R. (2000). Immigration as a Democratic Challenge: Citizenship and Inclusion in Germany and the United States. Cambridge, New York: Cambridge University Press.

Rubio Marin, R. (2006). Spain. In: Bauböck, R. et al. (eds.), Acquisition and Loss of Nationality. Policies and Trends in 15 European States. Volume 2: Country Analyses. Amsterdam: Amsterdam University Press, 477-516. 
Rumpf, C. (2003). Citizenship and Multiple Citizenship in Turkish Law. In: Martin, D. A. \& K. Hailbronner (eds.), Rights and Duties of Dual Nationals. Evolution and Prospects. The Hague, London, New York: Kluwer Law International, 361-374.

Sasse, G. (2005). Securitization or Securing Rights? Exploring the Conceptual Foundations of Policies towards Minorities and Migrants in Europe. Journal of Common Market Studies 43(4): 673-693.

Sasse, G. \& E. Thielemann (2005). A Research Agenda for the Study of Migrants and Minorities in Europe. Journal of Common Market Studies 43(4): 655-671.

Schnapauff, K.-D. (2003). Bosniak on the Postnational Transformation of Citizenship. In: Martin, D.A. \& K. Hailbronner (eds.), Rights and Duties of Dual Nationals. Evolution and Prospects. The Hague, London, New York: Kluwer Law International, 49-54.

Schröter, Y. \& R.S. Jäger (2007). Multiple citizenship in Germany. In: Kalekin-Fishman, D. \& P. Pitkänen (eds.), Multiple Citizenship as a Challenge to European Nation-States. Rotterdam: Sense Publishers, 81-120.

Schröter, Y., Mengelkamp, C. \& R. Jäger (2005) (eds.), Doppelte Staatsbürgerschaft, Landau: Verlag Empirische Padagogik.

Schuck, P.H. (2002). Plural Citizenships. In: Hansen, R. \& P. Weil (eds.), Dual nationality, social rights and federal citizenship in the US and Europe: the reinvention of citizenship. Berghahn Books, 61-99.

Shachar, A. (2000). Citizenship and Membership in the Israeli Polity. In: Aleinikoff, T.A. \& D. Klusmeyer (eds.). From migrants to citizens. Membership in a changing world. Washington: Carnegie Endowment for International Peace, 386-433.

Shevel, O. (2002). Nationality in Ukraine: Some Rules of Engagement. East European Politics and Societies 16: 386.

Shevel, O. (2004). Citizenship and nation-building in Ukraine. PAPER PRESENTED AT THE WORKSHOP Understanding the Transformation of Ukraine: Assessing What Has Been Learned, Devising a Research Agenda, Chair of Ukrainian Studies University of Ottawa (Canada) 15-16 October 2004.

Shiu-Hing L. (2001). Citizenship and Participation in Hong Kong. Citizenship Studies 5(2): 127142.

Skrobacki, W.A. (2007). Dual Citizenship, European Identity and Community-Building in Europe. In: Faist, T. \& P. Kivisto (eds.), Dual Citizenship in Global Perspective. From Unitary to Multiple Citizenship. Basingstoke: Palgrave Macmillan, 227-246.

Smith, L. \& G. Verma (2007). Dual Citizenship: The British position. In: Kalekin-Fishman, D. \& P. Pitkänen (eds.), Multiple Citizenship as a Challenge to European Nation-States. Rotterdam: Sense Publishers, 39-58.

Smith, R. M. (1997). Civic Ideals. Conflicting Visions of Citizenship in U.S. History. New Haven \& London: Yale University Press.

Smith, R.M. (2005). The Challenges Facing American Citizenship Today. PS: Political Science and Politics 38(4): 679-682.

Soysal, Y.N. (1994). Limits of Citizenship. Migrants and Postnational Membership in Europe. Chicago \& London: University of Chicago Press.

Spang, M. (2007). Pragmatism All the Way Down? The Politics of Dual Citizenship in Sweden. In: Faist, T. (ed.), Dual Citizenship in Europe. From Nationhood to Social Integration. Aldershot: Ashgate, 103-125.

Spire, A. \& P. Weil (2006). France. In: Bauböck, R. et al. (eds.), Acquisition and Loss of Nationality. Policies and Trends in 15 European States. Volume 2: Country Analyses. Amsterdam: Amsterdam University Press, 187-212.

Spiro, P. (1997). Dual Nationality and the Meaning of Citizenship. Emory Law Journal 46.

Spiro, P. (2002). Embracing Dual Nationality. In: Hansen, R. \& P. Weil (eds.), Dual nationality, social rights and federal citizenship in the US and Europe: the reinvention of citizenship. Berghahn Books, 19-33.

Spiro, P. (2003). Political Rights of Dual Nationals in Turkish Law. In: Martin, D.A. \& K. Hailbronner (eds.). Rights and Duties of Dual Nationals. Evolution and Prospects. The Hague, London, New York: Kluwer Law International, 135-152. 
Spiro, P. (2007). Dual Citizenship: A postnational view. In: Faist, T. \& P. Kivisto (eds.), Dual Citizenship in Global Perspective. From Unitary to Multiple Citizenship. Basingstoke: Palgrave Macmillan, 189-202.

Stasiulis, D. (2002). Introduction: Reconfiguring Canadian Citizenship. Citizenship Studies 6(4): 365-375.

Stasiulis, D. \& D. Ross (2006). Security, Flexible Sovereignty, and the Perils of Multiple Citizenship. Citizenship Studies 10(3): 329-348.

Staton, J., Jackson, R. \& D. Canache (2007). Dual Nationality Among Latinos: What are the implications for Political Connectedness? Journal of Politics 69(2): 470-482.

Straubhaar, T. (2002). Migration im 21. Jahrhundert. Von der Bedrohung zur Rettung sozialer Marktwirtschaften? Tübingen: Mohr Siebeck.

Studer, B. (2006). Das Schweizer Bürgerrecht von 1874 bis in die Gegenwart. <www.terracognita.ch/d/archiv.asp>

Symmons, C. R. (2001). Irish Nationality Law. In: Hansen, R. \& P. Weil (eds.), Towards a European Nationality. Citizenship, Immigration and Nationality Law in the EU. Basingstoke: Palgrave, 273-312.

Triadafilopoulos, T. (2007). Dual Citizenship and Security Norms in Historical Perspective. In: Faist, T. \& P. Kivisto (eds.), Dual Citizenship in Global Perspective. From Unitary to Multiple Citizenship. Basingstoke: Palgrave Macmillan, 27-41.

Trimikliniotis, N. (2007). Nationality and citizenship in Cyprus since 1945: Communal citizenship, gendered nationality \& the adventures of a post-colonial subject in a divided country. In: Bauböck, R., Perching, B. \& W. Sievers (eds.), Citizenship Policies in the New Europe. Amsterdam: Amsterdam University Press, 263-292.

Tsitselikis, K. (2007). Citizenship in Greece: Present challenges for future changes. In: KalekinFishman, D. \& P. Pitkänen (eds.), Multiple Citizenship as a Challenge to European NationStates. Rotterdam: Sense Publishers, 145-170.

Turner, B. S. (2000). Liberal Citizenship and Cosmopolitan Virtue. In: Vandenberg, A. (ed.), Citizenship and Citizenship in a Global Era. Houndsmill, Basingstoke, Hampshire: Macmillan, 1832.

Vandenberg, A. (2000) (ed.). Citizenship and Citizenship in a Global Era. Houndsmill, Basingstoke, Hampshire: Macmillan.

Vandenberg, A. (2000). Contesting Citizenship and Democracy in a Global Era. In: ibid. (ed.), Citizenship and Citizenship in a Global Era. Houndsmill, Basingstoke, Hampshire: Macmillan, 3-17.

Vargas, J. A. (2007). Nationality, Naturalization and Dual Nationality Under Mexican Law. San Diego Legal Studies Paper No. 82.

Waldinger, R. (2008). Between "Here" and "There": Immigrant Cross-Border Activities and Loyalties. International Migration Review 42(1).

Waldrauch, H. (2007). Acquisition of nationality. In: Bauböck, R et al. (eds.), Acquisition and Loss of Nationality. Policies and Trends in 15 European States. Volume 1: Comparative Analyses. Amsterdam: Amsterdam University Press, 121-182.

Waldrauch, H. (2007). Loss of nationality. In: Bauböck, R et al. (eds.), Acquisition and Loss of Nationality. Policies and Trends in 15 European States. Volume 1: Comparative Analyses. Amsterdam: Amsterdam University Press, 183-220.

Waldrauch, H. (2007). Methodology for comparing acquisition and loss of nationality. In: Bauböck, R. et al. (eds.), Acquisition and Loss of Nationality. Policies and Trends in 15 European States. Volume 1: Comparative Analyses. Amsterdam: Amsterdam University Press, 105120.

Waldrauch, H. (2007). Rights of Expatriates, multiple citizens and restricted citizenship for certain nationals. In: Bauböck, R. et al. (eds.), Acquisition and Loss of Nationality. Policies and Trends in 15 European States. Volume 1: Comparative Analyses. Amsterdam: Amsterdam University Press, 359-384.

Waldrauch, H. (2007). Statistics on acquisition and loss of nationality. In: Bauböck, R. et al. (eds.), Acquisition and Loss of Nationality. Policies and Trends in 15 European States. Volume 1: Comparative Analyses. Amsterdam: Amsterdam University Press, 269-316. 
Weil, P. (2001). Access to Citizenship: A comparison of twenty-five nationality laws. Aleinikoff, T.A. \& D. Klusmeyer (eds.), Citizenship Today. Global Perspectives and Practices. Washington, D.C.: Carnegie Endowment for International Peace, 17-35.

Weil, P. (2001). The History of French Nationality: A lesson for Europe. In: Hansen, R. \& P. Weil (eds.), Towards a European Nationality. Citizenship, Immigration and Nationality Law in the $E U$. Basingstoke: Palgrave, 52-68.

Werbner, P. (2000). Divided Loyalties, Empowered Citizenship? Muslims in Britain. Citizenship Studies 4 (3): 307-324.

Wetenschappelijke Raad voor het Regeringsbeleid (2007). Identificatie met Nederland. Amsterdam: Amsterdam University Press.

Wiedemann, M. (2003). Development of Dual Nationality under German Law. In: Martin, D.A. \& K. Hailbronner (eds.), Rights and Duties of Dual Nationals. Evolution and Prospects. The Hague, London, New York: Kluwer Law International, 335-346.

Wolton, Suke (2006). Immigration Policy and the "Crisis of British Values". Citizenship Studies 10 (4): 453-467.

Ziemele, I. (2001). State Continuity, Human Rights and Nationality in the Baltic States. In: Jundzis, T. (ed.), The Baltic States at Historical Crossroads. Riga: Academy of Sciences of Latvia, 224-248.

Ziemele, I. (2005). State Continuity and Nationality: The Baltic States and Russia. Past, Present and Future as Defined by International Law. Leiden, Boston: Martinus Nijhoff Publishers.

Zorn, J. (2005). Ethnic Citizenship in the Slovenian State. Citizenship Studies 9(2): 135-152. 
Appendix to chapter 1:

Table A: Information on surveys with information on dual citizenship

\begin{tabular}{|c|c|c|c|c|c|}
\hline Author/ Publisher & $\begin{array}{l}\text { Type of Information/Classification by the Authors } \\
\text { and the Transformation into Our Coding Scheme }\end{array}$ & $\begin{array}{l}\text { Number/ } \\
\text { Range of } \\
\text { Countries }\end{array}$ & $\begin{array}{l}\text { Year of data } \\
\text { collection }\end{array}$ & Ways of data collection & Bibliographic information \\
\hline $\begin{array}{l}\text { United States Office of } \\
\text { Personnel Manage- } \\
\text { ment, Investigations } \\
\text { Service }\end{array}$ & $\begin{array}{l}\text { The directory provides a very brief overview on the } \\
\text { citizenship laws of the world. For every country there is } \\
\text { a clear coding in respect to dual citizenship, either as } \\
\text { "recognized" or as "not recognized". No clear-cut } \\
\text { description is given on the criteria for this classifica- } \\
\text { tion. In the introduction it is stated that this coding } \\
\text { refers to the recognition "of a person's prerogative to } \\
\text { rights, privileges, or immunities that may be the pre- } \\
\text { rogatives of citizens of the other nation" (p. 6) but the } \\
\text { sections on the exceptions from the general approach to } \\
\text { dual citizenship point to the fact that not only the } \\
\text { treatment of dual citizens is taken into account but also } \\
\text { the rules for acquisition of dual citizenship. } \\
\text { For our overview, we stick to the basic dichotomous } \\
\text { coding: } \\
\text { a) recognized } \\
\text { b) not recognized }\end{array}$ & $\begin{array}{l}190 \\
\text { global }\end{array}$ & 2000 & $\begin{array}{l}\text { Information from embas- } \\
\text { sies, The Library of Con- } \\
\text { gress and the Department of } \\
\text { State }\end{array}$ & $\begin{array}{l}\text { United States Office of Personnel Management, } \\
\text { Investigations Service (2001): Citizenship Laws } \\
\text { of the World. } \\
<\text { <http://www.opm.gov/extra/investigati/IS-o1- } \\
\text { pfd> }\end{array}$ \\
\hline Stanley Renshon & $\begin{array}{l}\text { Renshon, a political scientist and leading anti-dual- } \\
\text { citizenship advocate takes into account all potential } \\
\text { ways by which a person in the United States may ac- } \\
\text { quire multiple citizenships. This leads to a very exten- } \\
\text { sive list of all countries who allow dual citizenship "in } \\
\text { some form." He includes also those countries have no } \\
\text { provision for dual citizenship but allow children of } \\
\text { nationals born abroad to retain their home-country } \\
\text { citizenship. We present only the "positive cases" men- }\end{array}$ & $\begin{array}{l}151 \\
\text { global, only } \\
\text { positive cases }\end{array}$ & $\begin{array}{l}\text { No explicit } \\
\text { information } \\
\text { (between } \\
\text { 2000-2004) }\end{array}$ & $\begin{array}{l}\text { Renshon draws on existing } \\
\text { academic publications and } \\
\text { did his own investigation by } \\
\text { contacting embassies. His } \\
\text { questions did not include } \\
\text { whether immigrants are } \\
\text { allowed to keep their former } \\
\text { citizenship but did only } \\
\text { focus on expatriates and }\end{array}$ & $\begin{array}{l}\text { Renshon, S. (2005): The 50\% American. Immi- } \\
\text { gration and National Identity in an Age of } \\
\text { Terror. Washington/DC: Georgetown Univer- } \\
\text { sity Press; list of countries which accept dual } \\
\text { citizenship is provided in the appendix, pp. } \\
\text { 255-260. }\end{array}$ \\
\hline
\end{tabular}




\begin{tabular}{|c|c|c|c|c|c|}
\hline & $\begin{array}{l}\text { tioned by Renshon where dual citizenship is "allowed" } \\
\text { since we do not know how far he has investigated into } \\
\text { all the other countries in our list. }\end{array}$ & & & $\begin{array}{l}\text { emigrants (Renshon 2005: } \\
\text { 32). }\end{array}$ & \\
\hline $\begin{array}{l}\text { Tanja Brondsted } \\
\text { Sejersen }\end{array}$ & $\begin{array}{l}\text { Sejersen, a social scientist, classifies the countries } \\
\text { according to whether they allow dual citizenship. We } \\
\text { transferred her five levels into three categories: } \\
\text { Dual citizenship } \\
\text { a) allowed [level 1: for the majority of the population] } \\
\text { b) allowed with treaty nations [level 2] } \\
\text { c) Not allowed [level 3: for children and adolescents } \\
\text { only, level 4: under special circumstances, level 5: } \\
\text { never] }\end{array}$ & $\begin{array}{l}115 \\
\text { (global) }\end{array}$ & 2007 & $\begin{array}{l}\text { Brondsted Sejerson ana- } \\
\text { lyzed official state Web } \\
\text { sites and journal and news- } \\
\text { paper articles }\end{array}$ & $\begin{array}{l}\text { Brondsted Sejersen, Tanja B. (2008): "I Vow to } \\
\text { Thee My Countries" - The Expansion of Dual } \\
\text { Citizenship in the 21st Century, in: IMR Vol. } \\
\text { 42, p. 523-549. }\end{array}$ \\
\hline
\end{tabular}




\begin{tabular}{|c|c|c|c|c|c|}
\hline Alfred M. Boll & $\begin{array}{l}\text { Boll, a legal scholar, discusses all aspects of multiple } \\
\text { nationality from the perspective of international law. } \\
\text { For } 76 \text { countries he provides detailed information: } \\
\text { a) on all possible events which lead to attribution/ } \\
\text { acquisition of nationality and its consequences in re- } \\
\text { spect to other nationalities (whether renunciation is a } \\
\text { necessary condition or whether naturalization leads to } \\
\text { the loss of other nationalities), and } \\
\text { b) on all possible events which lead to withdrawal/loss } \\
\text { of nationality. } \\
\text { We use three specific information for our coding: } \\
\text { A. Whether naturalization requires renunciation of } \\
\text { other nationality or leads to the automatic loss of other } \\
\text { nationalities } \\
\text { B. Whether naturalization elsewhere leads to the loss of } \\
\text { nationality in this country } \\
\text { C. The qualitative description provided under the head- } \\
\text { ing "general attitude toward multiple nationality" } \\
\text { Our categories and classification logic is the following: } \\
\text { a) recognized: if A and B = "no" and C provides no } \\
\text { strong detrimental information } \\
\text { b) tolerated: if A or/and B = "yes" but with major/many } \\
\text { exceptions and C indicates de facto tolerance } \\
\text { c) not tolerated: if A and B = "yes" and C reveals ad- } \\
\text { verse attitudes }\end{array}$ & $\begin{array}{l}76 \\
\text { (global) }\end{array}$ & $2005 / 2006$ & $\begin{array}{l}\text { Boll analyzied a broad array } \\
\text { of academic sources and } \\
\text { information available on the } \\
\text { internet. }\end{array}$ & $\begin{array}{l}\text { Boll, A.M (2007): Multiple Nationality and } \\
\text { International Law. Leiden/Boston: Martinus } \\
\text { Nijhoff Publishers; country information is } \\
\text { provided in the appendix, pp. 309-566. }\end{array}$ \\
\hline
\end{tabular}




\begin{tabular}{|c|c|c|c|c|c|}
\hline Patrick Weil & $\begin{array}{l}\text { Weil, a legal scholar, provides a comparison of all } \\
\text { aspects of citizenship laws for } 35 \text { countries. He lists for } \\
\text { every country whether those who want to naturalize } \\
\text { have to renounce their former citizenship. No detailed } \\
\text { information is given. } \\
\text { From his list we can directly extract the following } \\
\text { classification: } \\
\text { a) Renunciation of prior citizenship required } \\
\text { b) Renunciation not required. }\end{array}$ & $\begin{array}{l}25 \\
\text { (Western and } \\
\text { East European } \\
\text { countries) }\end{array}$ & 2000 & No information given & $\begin{array}{l}\text { Weil, P. (2001): Access to Citizenship: A com- } \\
\text { parison of Twenty-Five Nationality Laws. In: } \\
\text { Aleinikoff, Th. and D. B. Klusmeyer (eds).: } \\
\text { Citizenship Today: Global Perspectives and } \\
\text { Practices. Washington/DC: Brookings Institu- } \\
\text { tion Press, pp 17-35 [especially p. 22]. }\end{array}$ \\
\hline Isabelle Chopin & $\begin{array}{l}\text { Chopin, who works for the Migration Policy Group in } \\
\text { Brussels, collected information on the actual practices } \\
\text { in the acquisition of nationality (not just the de jure } \\
\text { situation). She classifies the countries according to the } \\
\text { requirement to renounce previous nationality in order to } \\
\text { acquire the nationality of this country. } \\
\text { Beyond the two basic categories: } \\
\text { a) renunciation required } \\
\text { b) renunciation not required, } \\
\text { she provides detailed information on the exceptions } \\
\text { which are made in many countries which formally } \\
\text { require renunciation. We try to keep some of this dif- } \\
\text { ferentiated information in our overview. }\end{array}$ & $\begin{array}{l}15 \\
\text { Older member } \\
\text { states of the } \\
\text { EU }\end{array}$ & $\begin{array}{l}\text { No explicit } \\
\text { information } \\
(2004 / 2005)\end{array}$ & $\begin{array}{l}\text { Chopin asked NGOs which } \\
\text { are active in the migration } \\
\text { policy field in every country } \\
\text { to fill in a questionnaire } \\
\text { about the practices in the } \\
\text { aquisition of nationalty. }\end{array}$ & $\begin{array}{l}\text { Chopin, Isabelle (2006): Administrative Prac- } \\
\text { tice in the Acquisition of nationality, in: } \\
\text { Bauböck et al. (ed.): Acquisition and Loss of } \\
\text { Nationality. Policies and Trends in } 15 \text { European } \\
\text { States. Volume 1: Comparative Analyses. } \\
\text { Amsterdam: Amsterdam University Press, 221- } \\
268 \text { [especially pages: } 251-255 \text { ] }\end{array}$ \\
\hline Marc Mojé Howard & $\begin{array}{l}\text { Howard, a political scientist, highlights the important } \\
\text { difference between "emigrant dual citizenship" and } \\
\text { "immigrant dual citizenship". He focuses on "immi- } \\
\text { grant dual citizenship" as "the much higher standard for } \\
\text { a liberal citizenship policy." We transfer his basic } \\
\text { classification of countries into two categories: Dual } \\
\text { citizenship } \\
\text { a) allowed for immigrants } \\
\text { b) not allowed for immigrants. }\end{array}$ & $\begin{array}{l}15 \\
\text { Older member } \\
\text { states of the } \\
\text { EU }\end{array}$ & 2004 & $\begin{array}{l}\text { Author analyzed the current } \\
\text { national citizenship laws. }\end{array}$ & $\begin{array}{l}\text { Howard, Marc M. (2005): Variation in Dual } \\
\text { Citizenship Policies in the Countries of the EU, } \\
\text { in: IMR Vol. 39, p. 697-720 [especially p. 709]. }\end{array}$ \\
\hline
\end{tabular}




\begin{tabular}{|c|c|c|c|c|c|}
\hline $\begin{array}{l}\text { Michael Jones- Cor- } \\
\text { rera }\end{array}$ & $\begin{array}{l}\text { Jones-Correra, apolitical scientist, presents a table with } \\
\text { data on whether Latin American and Caribbean states } \\
\text { recognize dual citizenship. } \\
\text { We transfer his information into three categories: Dual } \\
\text { citizenship } \\
\text { a) recognized [J-C: yes] } \\
\text { b) recognized with treaty nations [J-C: no + only with } \\
\text { treaty nations] } \\
\text { c) not recognized.[J.-C: no] }\end{array}$ & $\begin{array}{l}33 \\
\text { Latin Ameri- } \\
\text { can and Car- } \\
\text { ibbean coun- } \\
\text { tries }\end{array}$ & 2000 & $\begin{array}{l}\text { Jones-Correra consulted } \\
\text { sources from migration } \\
\text { organizations and contacted } \\
\text { embassies and consulates. }\end{array}$ & $\begin{array}{l}\text { Jones-Carrera, M. (2001): Under Two Flags: } \\
\text { Dual Nationality in Latin America and its Con- } \\
\text { sequences for Naturalization in the United } \\
\text { States. In: International Migration Review, 35, } \\
\text { 997-1029 [table on p. 999] }\end{array}$ \\
\hline $\begin{array}{l}\text { Jeffrey Staton, Robert } \\
\text { Jackson and Damarys } \\
\text { Canache }\end{array}$ & $\begin{array}{l}\text { The authors, political scientists, classify Latin Ameri- } \\
\text { can countries according to whether they allow for dual } \\
\text { national status. Since the context of this study is immi- } \\
\text { gration into the U.S., the results reflect whether emi- } \\
\text { grants from these countries loose their nationality if the } \\
\text { apply for citizenship in the U.S. It is not clear how } \\
\text { symmetric the citizenship regulations are and whether } \\
\text { immigrants in these countries are treated equally to } \\
\text { emigrants. } \\
\text { We have two categories: } \\
\text { Dual citizenship } \\
\text { a) allowed for emigrants } \\
\text { b) not allowed for emigrants. }\end{array}$ & $\begin{array}{l}20 \text { (Latin } \\
\text { America) }\end{array}$ & 2005 & $\begin{array}{l}\text { The authors conducted } \\
\text { telephone interview with } \\
\text { embassies and consulates. }\end{array}$ & $\begin{array}{l}\text { Staton, Jeffrey K., Jackson, Robert and Ca- } \\
\text { nache, Damarys, "Costly Citizenship? Dual } \\
\text { Nationality Institutions, Naturalization, and } \\
\text { Political Connectedness" (June 19,2007). } \\
\text { Available at SSRN: } \\
\text { http/ssm.com/abstract=995569 }\end{array}$ \\
\hline
\end{tabular}


Table B: Detailed results of surveys on the acceptance of dual citizenship

\begin{tabular}{|c|c|c|c|c|c|c|c|c|c|}
\hline $\begin{array}{l}\text { List of investi- } \\
\text { gated Countries }\end{array}$ & $\begin{array}{l}\text { US Office of } \\
\text { Personnel } \\
\text { Management } \\
(2001) \\
\end{array}$ & $\begin{array}{l}\text { Stanley Ren- } \\
\text { shon (2005) }\end{array}$ & $\begin{array}{l}\text { Tanja Brond- } \\
\text { sted Sejersen } \\
(2008)\end{array}$ & $\begin{array}{l}\text { Alfred M. } \\
\text { Boll } \\
(2007)\end{array}$ & $\begin{array}{l}\text { Patrick } \\
\text { Weil } \\
(2001)\end{array}$ & $\begin{array}{l}\text { Isabelle } \\
\text { Chopin } \\
(2006)\end{array}$ & $\begin{array}{l}\text { Marc Mojé } \\
\text { Howard } \\
(2005)\end{array}$ & $\begin{array}{l}\text { Michael Jones- } \\
\text { Correra } \\
(2001)\end{array}$ & $\begin{array}{l}\text { Jeffrey Staton } \\
\text { et al. } \\
(2007)\end{array}$ \\
\hline 189 & 184 (190 orig.) & 144 (151 orig.) & 115 & 76 & 25 & 15 & 15 & 33 & 20 \\
\hline $\begin{array}{l}\text { geographical } \\
\text { orientation }\end{array}$ & global & global & global & global & $\begin{array}{l}\text { Western and East } \\
\text { European States }\end{array}$ & $\begin{array}{l}\text { Older member } \\
\text { states of the EU }\end{array}$ & $\begin{array}{l}\text { Older member } \\
\text { states of the EU }\end{array}$ & $\begin{array}{l}\text { Latin American and } \\
\text { Caribbean Coun- } \\
\text { tries }\end{array}$ & Latin America \\
\hline $\begin{array}{l}\text { classification } \\
\text { concerning }\end{array}$ & $\begin{array}{l}\text { Dual citizenship } \\
\text { recognized/ not } \\
\text { recognized }\end{array}$ & $\begin{array}{l}\text { Dual citizenship } \\
\text { allowed "in some } \\
\text { form" (no informa- } \\
\text { tion about negative } \\
\text { cases) }\end{array}$ & $\begin{array}{l}\text { Dual citizenship } \\
\text { allowed/ allowed } \\
\text { for citizens from } \\
\text { treaty nations/ not } \\
\text { allowed }\end{array}$ & $\begin{array}{l}\text { Dual citizenship } \\
\text { recognized/toler- } \\
\text { ated/ not tolerated } \\
\text { (in respect to } \\
\text { naturalization) }\end{array}$ & $\begin{array}{l}\text { For naturalization } \\
\text { renunciation of } \\
\text { prior citizenship } \\
\text { required/ not re- } \\
\text { quired }\end{array}$ & $\begin{array}{l}\text { For naturalization } \\
\text { renunciation of } \\
\text { original citizenship } \\
\text { required/not re- } \\
\text { quired }\end{array}$ & $\begin{array}{l}\text { Dual citizenship } \\
\text { allowed/ not al- } \\
\text { lowed for immi- } \\
\text { grants }\end{array}$ & $\begin{array}{l}\text { Dual Citizenship } \\
\text { recognized/ recog- } \\
\text { nized for citizens } \\
\text { from treaty nations/ } \\
\text { not recognized }\end{array}$ & $\begin{array}{l}\text { Dual citizenship } \\
\text { allowed/ not al- } \\
\text { lowed for emigrants }\end{array}$ \\
\hline Afghanistan & not recognized & & allowed & & & & & & \\
\hline Albania & n.a. & allowed & allowed & & & & & & \\
\hline Algeria & not recognized & & & & & & & & \\
\hline Andorra & not recognized & & & & & & & & \\
\hline Angola & not recognized & allowed & & & & & & & \\
\hline $\begin{array}{l}\text { Antigua and } \\
\text { Barbuda }\end{array}$ & recognized & allowed & & & & & & recognized & \\
\hline Argentina & not recognized & allowed & $\begin{array}{l}\text { allowed with } \\
\text { treaty nations }\end{array}$ & recognized & & & & $\begin{array}{l}\text { recognized with } \\
\text { treaty nations }\end{array}$ & not allowed \\
\hline Armenia & not recognized & & allowed & & & & & & \\
\hline Australia & recognized & allowed & allowed & recognized & $\begin{array}{l}\text { renunciation } \\
\text { not required }\end{array}$ & & & & \\
\hline
\end{tabular}




\begin{tabular}{|c|c|c|c|c|c|c|c|c|c|}
\hline Austria & not recognized & & not allowed & $\begin{array}{l}\text { tolerated (for } \\
\text { emigrants) }\end{array}$ & $\begin{array}{l}\text { renunciation } \\
\text { required }\end{array}$ & $\begin{array}{l}\text { renunciation } \\
\text { required, but } \\
\text { some excep- } \\
\text { tions }\end{array}$ & not allowed & & \\
\hline Azerbaijan & not recognized & & not allowed & & & & & & \\
\hline Bahamas & not recognized & allowed & not allowed & & & & & not recognized & \\
\hline Bahrain & not recognized & & $\begin{array}{l}\text { allowed with } \\
\text { treaty nations }\end{array}$ & & & & & & \\
\hline Bangladesh & not recognized & allowed & allowed & & & & & & \\
\hline Barbados & recognized & allowed & allowed & recognized & & & & recognized & \\
\hline Belarus & not recognized & allowed & allowed & tolerated & & & & & \\
\hline Belgium & not recognized & allowed & $\begin{array}{l}\text { allowed with } \\
\text { treaty nations }\end{array}$ & not tolerated & $\begin{array}{l}\text { renunciation } \\
\text { not required }\end{array}$ & $\begin{array}{l}\text { renunciation } \\
\text { not required }\end{array}$ & allowed & & \\
\hline Belize & recognized & allowed & allowed & & & & & recognized & \\
\hline Benin & recognized & allowed & & & & & & & \\
\hline Bhutan & not recognized & & not allowed & & & & & & \\
\hline Bolivia & not recognized & allowed & not allowed & & & & & not recognized & not allowed \\
\hline $\begin{array}{l}\text { Bosnia and Her- } \\
\text { zegovina }\end{array}$ & n.a. & & allowed & & & & & & \\
\hline Botswana & not recognized & allowed & & & & & & & \\
\hline Brazil & not recognized & allowed & allowed & recognized & & & & recognized & allowed \\
\hline $\begin{array}{l}\text { Brunei Darussa- } \\
\text { lam }\end{array}$ & not recognized & allowed & not allowed & & & & & & \\
\hline Bulgaria & recognized & allowed & allowed & & & & & & \\
\hline Burkina Faso & recognized & allowed & & & & & & & \\
\hline Burundi & not recognized & & & & & & & & \\
\hline Cambodia & not recognized & allowed & not allowed & & & & & & \\
\hline Cameroon & not recognized & allowed & & & & & & & \\
\hline
\end{tabular}




\begin{tabular}{|c|c|c|c|c|c|c|c|c|c|}
\hline Canada & recognized & allowed & allowed & recognized & $\begin{array}{l}\text { renunciation } \\
\text { not required }\end{array}$ & & & & \\
\hline Cape Verde & recognized & allowed & & & & & & & \\
\hline $\begin{array}{l}\text { Central African } \\
\text { Republic }\end{array}$ & recognized & allowed & & & & & & & \\
\hline Chile & not recognized & allowed & $\begin{array}{l}\text { allowed with } \\
\text { treaty nations }\end{array}$ & recognized & & & & $\begin{array}{l}\text { recognized with } \\
\text { treaty nations }\end{array}$ & not allowed \\
\hline China & not recognized & & not allowed & not tolerated & & & & & \\
\hline Colombia & recognized & allowed & allowed & recognized & & & & recognized & allowed \\
\hline $\begin{array}{l}\text { Congo (formerly } \\
\text { Zaire) }\end{array}$ & not recognized & allowed & & & & & & & \\
\hline $\begin{array}{l}\text { Congo, Democ- } \\
\text { ratic Republic of } \\
\text { the }\end{array}$ & not recognized & & & & & & & & \\
\hline Cook Islands & & & & recognized & & & & & \\
\hline Costa Rica & recognized & allowed & allowed & recognized & & & & recognized & allowed \\
\hline $\begin{array}{l}\text { Côte d'Ivoire } \\
\text { (formerly Ivory } \\
\text { Coast) }\end{array}$ & recognized & allowed & & tolerated & & & & & \\
\hline Croatia & not recognized & allowed & not allowed & & & & & & \\
\hline Cuba & not recognized & & & & & & & not recognized & not allowed \\
\hline Cyprus & recognized & allowed & allowed & tolerated & & & & & \\
\hline Czech Republic & not recognized & & not allowed & tolerated & & & & & \\
\hline Denmark & not recognized & allowed & not allowed & & $\begin{array}{l}\text { renunciation } \\
\text { not required }\end{array}$ & $\begin{array}{l}\text { renunciation } \\
\text { required, rather } \\
\text { strict enforce- } \\
\text { ment } \\
\end{array}$ & not allowed & & \\
\hline Djibouti & not recognized & & & & & & & & \\
\hline Dominica & n.a. & allowed & & & & & & recognized & \\
\hline
\end{tabular}




\begin{tabular}{|c|c|c|c|c|c|c|c|c|c|}
\hline $\begin{array}{l}\text { Dominican Re- } \\
\text { public }\end{array}$ & not recognized & allowed & & & & & & recognized & allowed \\
\hline Ecuador & not recognized & allowed & allowed & recognized & & & & recognized & allowed \\
\hline Egypt & not recognized & allowed & allowed & recognized & & & & & \\
\hline El Salvador & recognized & allowed & allowed & & & & & recognized & allowed \\
\hline $\begin{array}{l}\text { Equatorial } \\
\text { Guinea } \\
\end{array}$ & not recognized & & & & & & & & \\
\hline Eritrea & not recognized & allowed & & & & & & & \\
\hline Estonia & not recognized & & not allowed & & $\begin{array}{l}\text { renunciation } \\
\text { not required }\end{array}$ & & & & \\
\hline Fiji & not recognized & allowed & not allowed & not tolerated & & & & & \\
\hline Finland & not recognized & allowed & allowed & recognized & $\begin{array}{l}\text { renunciation } \\
\text { not required }\end{array}$ & $\begin{array}{l}\text { renunciation } \\
\text { not required }\end{array}$ & allowed & & \\
\hline France & recognized & allowed & allowed & recognized & $\begin{array}{l}\text { renunciation } \\
\text { not required }\end{array}$ & $\begin{array}{l}\text { renunciation } \\
\text { not required }\end{array}$ & allowed & & \\
\hline Gabon & not recognized & & & & & & & & \\
\hline Gambia & not recognized & allowed & & & & & & & \\
\hline Georgia & n.a. & & not allowed & & & & & & \\
\hline Germany & not recognized & allowed & not allowed & tolerated & $\begin{array}{l}\text { renunciation } \\
\text { required }\end{array}$ & $\begin{array}{l}\text { renunciation } \\
\text { required, but } \\
\text { many excep- } \\
\text { tions }\end{array}$ & not allowed & & \\
\hline Ghana & not recognized & allowed & & recognized & & & & & \\
\hline Greece & not recognized & allowed & allowed & recognized & $\begin{array}{l}\text { renunciation } \\
\text { not required }\end{array}$ & $\begin{array}{l}\text { renunciation } \\
\text { not required }\end{array}$ & allowed & & \\
\hline Grenada & recognized & allowed & allowed & & & & & not recognized & \\
\hline Guatemala & not recognized & allowed & not allowed & tolerated & & & & $\begin{array}{l}\text { recognized with } \\
\text { treaty nations }\end{array}$ & not allowed \\
\hline Guinea & not recognized & & & & & & & & \\
\hline
\end{tabular}




\begin{tabular}{|c|c|c|c|c|c|c|c|c|c|}
\hline Guinea-Bissau & not recognized & allowed & not allowed & & & & & & \\
\hline Guyana & not recognized & allowed & & & & & & not recognized & \\
\hline Haiti & not recognized & allowed & & & & & & not recognized & not allowed \\
\hline Honduras & recognized & allowed & allowed & & & & & $\begin{array}{l}\text { recognized with } \\
\text { treaty nations }\end{array}$ & not allowed \\
\hline Hong Kong & & & & tolerated & & & & & \\
\hline Hungary & recognized & allowed & allowed & recognized & & & & & \\
\hline Iceland & not recognized & allowed & allowed & recognized & & & & & \\
\hline India & not recognized & allowed & allowed & not tolerated & & & & & \\
\hline Indonesia & not recognized & & not allowed & not tolerated & & & & & \\
\hline Iran & not recognized & allowed & not allowed & recognized & & & & & \\
\hline Iraq & n.a. & allowed & & & & & & & \\
\hline Ireland & recognized & allowed & allowed & recognized & $\begin{array}{l}\text { renunciation } \\
\text { not required }\end{array}$ & $\begin{array}{l}\text { renunciation } \\
\text { not required }\end{array}$ & allowed & & \\
\hline Israel & recognized & allowed & allowed & tolerated & $\begin{array}{l}\text { renunciation } \\
\text { required }\end{array}$ & & & & \\
\hline Italy & recognized & allowed & allowed & recognized & $\begin{array}{l}\text { renunciation } \\
\text { not required }\end{array}$ & $\begin{array}{l}\text { renunciation } \\
\text { not required }\end{array}$ & allowed & & \\
\hline Jamaica & recognized & allowed & allowed & recognized & & & & recognized & allowed \\
\hline Japan & not recognized & allowed & not allowed & not tolerated & & & & & \\
\hline Jordan & recognized & allowed & allowed & & & & & & \\
\hline Kazakhstan & not recognized & & not allowed & & & & & & \\
\hline Kenya & not recognized & & & not tolerated & & & & & \\
\hline Kiribati & not recognized & & & & & & & & \\
\hline Kuwait & not recognized & & $\begin{array}{l}\text { allowed with } \\
\text { treaty nations }\end{array}$ & & & & & & \\
\hline Kyrgyzstan & not recognized & & not allowed & & & & & & \\
\hline
\end{tabular}




\begin{tabular}{|c|c|c|c|c|c|c|c|c|c|}
\hline $\begin{array}{l}\text { Lao People's } \\
\text { Democratic Re- } \\
\text { public }\end{array}$ & not recognized & & not allowed & & & & & & \\
\hline Latvia & not recognized & allowed & allowed & not tolerated & $\begin{array}{l}\text { renunciation } \\
\text { not required }\end{array}$ & & & & \\
\hline Lebanon & recognized & allowed & allowed & & & & & & \\
\hline Lesotho & not recognized & allowed & & & & & & & \\
\hline Liberia & not recognized & allowed & & & & & & & \\
\hline $\begin{array}{l}\text { Libyan Arab } \\
\text { Jamahiriya }\end{array}$ & not recognized & & & & & & & & \\
\hline Liechtenstein & & allowed & & & & & & & \\
\hline Lithuania & not recognized & allowed & allowed & & $\begin{array}{l}\text { renunciation } \\
\text { required }\end{array}$ & & & & \\
\hline Luxembourg & not recognized & allowed & not allowed & tolerated & $\begin{array}{l}\text { renunciation } \\
\text { required }\end{array}$ & $\begin{array}{l}\text { renunciation } \\
\text { required }\end{array}$ & not allowed & & \\
\hline Macedonia & & allowed & not allowed & & & & & & \\
\hline Madagascar & not recognized & allowed & & & & & & & \\
\hline Malawi & not recognized & allowed & & & & & & & \\
\hline Malaysia & not recognized & & not allowed & $\begin{array}{l}\text { tolerated } \\
\text { (discretionary) }\end{array}$ & & & & & \\
\hline Maldives & recognized & allowed & & & & & & & \\
\hline Mali & recognized & allowed & & & & & & & \\
\hline Malta & not recognized & allowed & allowed & & & & & & \\
\hline Marshall Islands & not recognized & & & & & & & & \\
\hline Mauritania & not recognized & allowed & & & & & & & \\
\hline Mauritius & recognized & allowed & & & & & & & \\
\hline Mexico & recognized & allowed & allowed & tolerated & $\begin{array}{l}\text { renunciation } \\
\text { required }\end{array}$ & & & recognized & allowed \\
\hline
\end{tabular}




\begin{tabular}{|c|c|c|c|c|c|c|c|c|c|}
\hline $\begin{array}{l}\text { Micronesia, Fed- } \\
\text { erated States of }\end{array}$ & not recognized & & & & & & & & \\
\hline Moldova & not recognized & allowed & allowed & & & & & & \\
\hline Monaco & not recognized & & & & & & & & \\
\hline Mongolia & not recognized & & not allowed & & & & & & \\
\hline Morocco & recognized & allowed & & recognized & & & & & \\
\hline Mozambique & not recognized & allowed & & & & & & & \\
\hline Myanmar & not recognized & allowed & not allowed & & & & & & \\
\hline Namibia & not recognized & allowed & & & & & & & \\
\hline Nauru & not recognized & & & & & & & & \\
\hline Nepal & not recognized & allowed & \begin{tabular}{|l|} 
not allowed \\
\end{tabular} & & & & & & \\
\hline Netherlands & not recognized & allowed & $\begin{array}{l}\text { allowed with } \\
\text { treaty nations }\end{array}$ & tolerated & $\begin{array}{l}\text { renunciation } \\
\text { not required }\end{array}$ & $\begin{array}{l}\text { renunciation } \\
\text { required, but } \\
\text { many excep- } \\
\text { tions }\end{array}$ & allowed & & \\
\hline New Zealand & recognized & allowed & allowed & recognized & & & & & \\
\hline Nicaragua & not recognized & allowed & $\begin{array}{l}\text { allowed with } \\
\text { treaty nations }\end{array}$ & & & & & $\begin{array}{l}\text { recognized with } \\
\text { treaty nations }\end{array}$ & allowed \\
\hline Niger & not recognized & allowed & & & & & & & \\
\hline Nigeria & recognized & allowed & & recognized & & & & & \\
\hline North Korea & not recognized & allowed & not allowed & & & & & & \\
\hline Norway & not recognized & & $\begin{array}{l}\text { allowed with } \\
\text { treaty nations }\end{array}$ & not tolerated & & & & & \\
\hline Oman & not recognized & allowed & not allowed & & & & & & \\
\hline Pakistan & not recognized & allowed & $\begin{array}{l}\text { allowed with } \\
\text { treaty nations }\end{array}$ & & & & & & \\
\hline Palau & not recognized & allowed & & & & & & & \\
\hline Panama & not recognized & allowed & allowed & & & & & recognized & allowed \\
\hline Papua New & not recognized & allowed & not allowed & & & & & & \\
\hline
\end{tabular}




\begin{tabular}{|c|c|c|c|c|c|c|c|c|c|}
\hline Guinea & & & & & & & & & \\
\hline Paraguay & recognized & allowed & $\begin{array}{l}\text { allowed with } \\
\text { treaty nations }\end{array}$ & recognized & & & & $\begin{array}{l}\text { recognized with } \\
\text { treaty nations }\end{array}$ & \\
\hline Peru & recognized & allowed & allowed & tolerated & & & & recognized & allowed \\
\hline Philippines & not recognized & allowed & allowed & tolerated & & & & & \\
\hline Poland & not recognized & allowed & not allowed & $\begin{array}{l}\text { recognized for } \\
\text { emigrants }\end{array}$ & & & & & \\
\hline Portugal & recognized & allowed & allowed & recognized & $\begin{array}{l}\text { renunciation } \\
\text { not required }\end{array}$ & $\begin{array}{l}\text { renunciation } \\
\text { not required }\end{array}$ & allowed & & \\
\hline Qatar & not recognized & allowed & not allowed & & & & & & \\
\hline Romania & recognized & allowed & allowed & recognized & & & & & \\
\hline $\begin{array}{l}\text { Russian Federa- } \\
\text { tion }\end{array}$ & recognized & allowed & allowed & tolerated & $\begin{array}{l}\text { renunciation } \\
\text { not required }\end{array}$ & & & & \\
\hline Rwanda & not recognized & allowed & & & & & & & \\
\hline $\begin{array}{l}\text { Saint Kitts (Saint } \\
\text { Christopher) and } \\
\text { Nevis }\end{array}$ & recognized & allowed & & & & & & recognized & \\
\hline Saint Lucia & recognized & allowed & & & & & & recognized & \\
\hline Saint Vincent & recognized & allowed & & & & & & recognized & \\
\hline Samoa & not recognized & allowed & allowed & recognized & & & & & \\
\hline $\begin{array}{l}\text { Sao Tome and } \\
\text { Principe }\end{array}$ & not recognized & & & & & & & & \\
\hline Saudi Arabia & not recognized & & $\begin{array}{l}\text { allowed with } \\
\text { treaty nations }\end{array}$ & & & & & & \\
\hline Senegal & not recognized & allowed & & & & & & & \\
\hline Serbia & n.a. & allowed & & & & & & & \\
\hline Seychelles & not recognized & & & & & & & & \\
\hline Sierra Leone & not recognized & allowed & & & & & & & \\
\hline Singapore & not recognized & allowed & not allowed & tolerated & & & & & \\
\hline
\end{tabular}




\begin{tabular}{|c|c|c|c|c|c|c|c|c|c|}
\hline Slovak Republic & recognized & allowed & allowed & & & & & & \\
\hline Slovenia & not recognized & allowed & allowed & tolerated & & & & & \\
\hline Solomon Islands & not recognized & & & & & & & & \\
\hline South Africa & recognized & allowed & allowed & tolerated & $\begin{array}{l}\text { renunciation } \\
\text { not required }\end{array}$ & & & & \\
\hline South Korea & not recognized & allowed & not allowed & not tolerated & & & & & \\
\hline Spain & not recognized & allowed & $\begin{array}{l}\text { allowed with } \\
\text { treaty nations }\end{array}$ & tolerated & $\begin{array}{l}\text { renunciation } \\
\text { not required }\end{array}$ & $\begin{array}{l}\text { renunciation } \\
\text { not required }\end{array}$ & not allowed & & \\
\hline Sri Lanka & not recognized & allowed & allowed & & & & & & \\
\hline Sudan & not recognized & allowed & & & & & & & \\
\hline Suriname & n.a. & & not allowed & & & & & not recognized & \\
\hline Swaziland & not recognized & allowed & & & & & & & \\
\hline Sweden & not recognized & allowed & allowed & recognized & $\begin{array}{l}\text { renunciation } \\
\text { not required }\end{array}$ & \begin{tabular}{|l|} 
renunciation \\
not required \\
\end{tabular} & allowed & & \\
\hline Switzerland & recognized & allowed & allowed & recognized & & & & & \\
\hline Syria & recognized & allowed & $\begin{array}{l}\text { allowed with } \\
\text { treaty nations }\end{array}$ & recognized & & & & & \\
\hline Taiwan & not recognized & allowed & & recognized & & & & & \\
\hline Tajikistan & n.a. & & $\begin{array}{l}\text { allowed with } \\
\text { treaty nations }\end{array}$ & & & & & & \\
\hline Tanzania & not recognized & allowed & & & & & & & \\
\hline Thailand & not recognized & allowed & not allowed & tolerated & & & & & \\
\hline East-Timor & & & not allowed & recognized & & & & & \\
\hline Togo & recognized & allowed & & & & & & & \\
\hline Tonga & not recognized & allowed & & tolerated & & & & & \\
\hline $\begin{array}{l}\text { Trinidad and } \\
\text { Tobago }\end{array}$ & recognized & allowed & allowed & recognized & & & & recognized & allowed \\
\hline Tunisia & recognized & allowed & & & & & & & \\
\hline Turkey & recognized & allowed & allowed & recognized & & & & & \\
\hline
\end{tabular}




\begin{tabular}{|c|c|c|c|c|c|c|c|c|c|}
\hline Turkmenistan & n.a. & & not allowed & & & & & & \\
\hline Tuvalu & recognized & allowed & & tolerated & & & & & \\
\hline Uganda & not recognized & allowed & & & & & & & \\
\hline Ukraine & not recognized & allowed & not allowed & & & & & & \\
\hline $\begin{array}{l}\text { United Arab } \\
\text { Emirates }\end{array}$ & not recognized & allowed & $\begin{array}{l}\text { allowed with } \\
\text { treaty nations }\end{array}$ & & & & & & \\
\hline United Kingdom & recognized & allowed & allowed & recognized & $\begin{array}{l}\text { renunciation } \\
\text { not required }\end{array}$ & $\begin{array}{l}\text { renunciation } \\
\text { not required }\end{array}$ & allowed & & \\
\hline $\begin{array}{l}\text { United States of } \\
\text { America }\end{array}$ & recognized & allowed & allowed & recognized & \begin{tabular}{|l|}
$\begin{array}{l}\text { renunciation } \\
\text { required }\end{array}$ \\
\end{tabular} & & & & \\
\hline Uruguay & recognized & allowed & allowed & tolerated & & & & recognized & \\
\hline Uzbekistan & not recognized & allowed & not allowed & & & & & & \\
\hline Vanuatu & not recognized & allowed & & not tolerated & & & & & \\
\hline Venezuela & not recognized & allowed & not allowed & recognized & & & & not recognized & not allowed \\
\hline Vietnam & not recognized & allowed & not allowed & & & & & & \\
\hline Yemen & not recognized & allowed & & & & & & & \\
\hline Zambia & not recognized & allowed & & & & & & & \\
\hline Zimbabwe & not recognized & allowed & & not tolerated & & & & & \\
\hline
\end{tabular}

\section{Note:}

empty cell $=$ country not included in study; n.a. $=$ country included but no information available definition of colored coding:

\begin{tabular}{|l|l|}
\hline 1 & countries with no acceptance of dual citizenship \\
\hline 2 & countries with a very limited acceptance of dual citizenship \\
\hline 3 & countries with inconsistent results \\
\hline 4 & countries which accept dual citizenship with treaty nations or tolerate dual citizenship de facto \\
\hline 5 & countries with full acceptance of dual citizenship \\
\hline
\end{tabular}

